\title{
COMUNIDADES DE FUNGOS MICORRÍZICOS ARBUSCULARES NOS MANEJOS CONVENCIONAL E ORGÂNICO DE CITROS E SUAS INTERAÇÕES COM Phytophthora parasitica
}

\author{
SORAYA DE CARVALHO FRANÇA
}

Tese apresentada à Escola Superior de Agricultura "Luiz de Queiroz", Universidade de São Paulo, para obtenção do título de Doutor em Agronomia, Área de Concentração: Microbiologia Agrícola.

P I R A C I C A B A

Estado de São Paulo - Brasil

Março - 2004 


\title{
COMUNIDADES DE FUNGOS MICORRÍZICOS ARBUSCULARES NOS MANEJOS CONVENCIONAL E ORGÂNICO DE CITROS E SUAS INTERAÇÕES COM Phytophthora parasitica
}

\author{
SORAYA DE CARVALHO FRANÇA
}

Engenheira Agrônoma

Orientadora: Profa. Dra. ADRIANA PARADA DIAS DA SILVEIRA

Tese apresentada à Escola Superior de Agricultura "Luiz de Queiroz", Universidade de São Paulo, para obtenção do título de Doutor em Agronomia, Área de Concentração: Microbiologia Agrícola.

P I R A C I C A B A

Estado de São Paulo - Brasil

Março - 2004 
Dados Internacionais de Catalogação na Publicação (CIP)
DIVISÃO DE BIBLIOTECA E DOCUMENTAÇÃO - ESALQ/USP

França, Soraya de Carvalho

Comunidades de fungos micorrízicos arbusculares nos manejos convencional e orgânico de citros e suas interações com Phytophthora parasitica / Soraya de Carvalho França. - - Piracicaba, 2004.

106 p. il.

Tese (doutorado) - Escola Superior de Agricultura Luiz de Queiroz, 2004.

Bibliografia.

1. Agricultura orgânica 2. Fruta cítrica 3. Fungo micorrízico 4. Gomose 5. Limão 6 Micorriza 7. Podridão-da-raiz 8. Quitinase I. Título

CDD 634.3 
Gracias a la vida

que me ha dado tanto

me ha dado el sonido

y el abecedario

con él las palabras

que pienso y declaro

(Violeta Parra) 
Aos meus pais Marcello e Rachel por todo amor e apoio durante mais essa etapa da minha vida.

A minha irmã Simone, meu cunhado Carlos e meus sobrinhos Eugênia e Julio pelos muitos momentos de alegria.

Ao meu companheiro Raf por estar sempre disposto a escutar, discutir e contribuir. 


\section{AGRADECIMENTOS}

\section{Instituto Agronômico -IAC}

Minha orientadora: Profa. Adriana P.D. Silveira

Pesquisadoras Sueli Freitas e Maria Luiza Lombardi

Técnicas Rosana G. Gierts e Maria Tereza B.

Mangussi

Funcionários Léo e Seu Lazinho.

Colegas Deise, Márcia, Sara, Valéria,

Vanessa, Karina, Mirela, Adriana, Silvana,

José Augusto e Alexandre

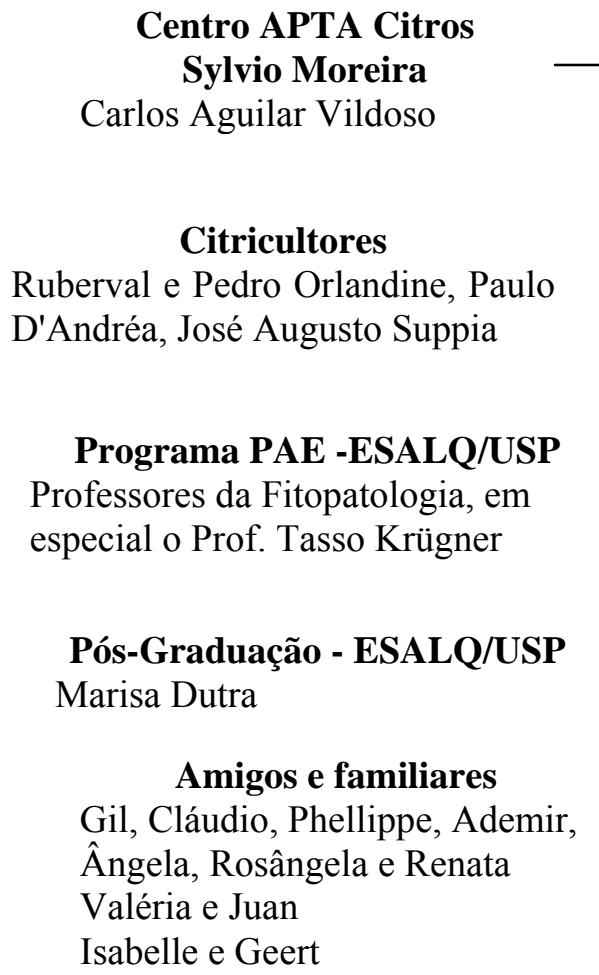

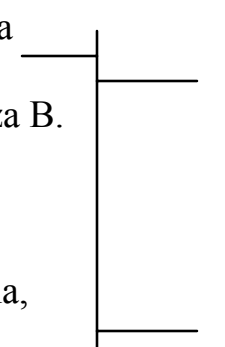

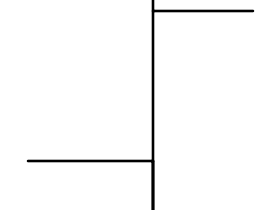




\section{SUMÁRIO}

Página

RESUMO ….............................................................................. viii

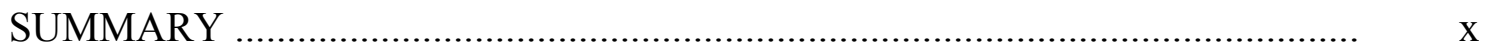

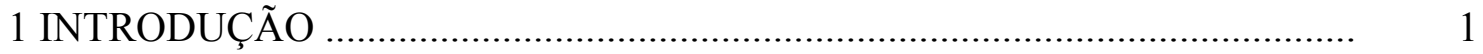

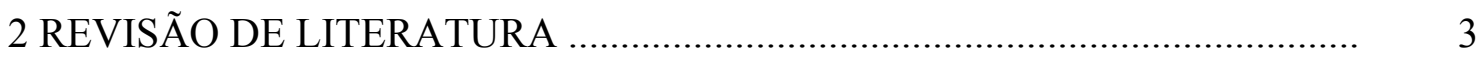

2.1 Manejo de problemas fitossanitários na citricultura brasileira ........................ 3

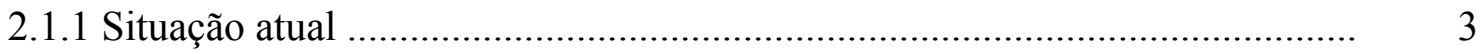

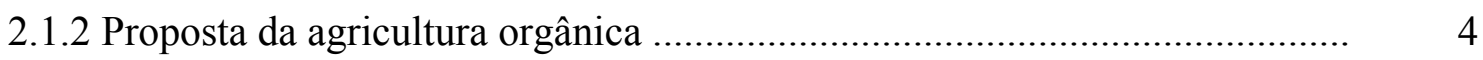

2.2 Phytophthora parasitica Dastur $(\sin =$ P. nicotianae Breda de Haan) ............. 6

2.3 Fungos micorrízicos arbusculares (FMAs) ............................................... 6

2.4 Interações de plantas, FMAs e P. parasitica .................................................... 9

3 ATIVIDADE MICROBIANA E DIVERSIDADE DE FUNGOS

MICORRÍZICOS ARBUSCULARES EM AGROECOSSISTEMAS

CONVENCIONAL E ORGÂNICO DE CITROS ….......................................... 12

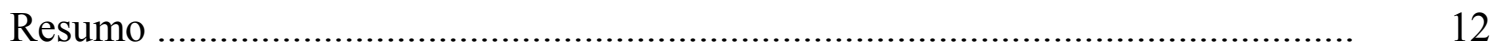

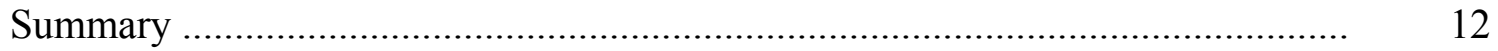

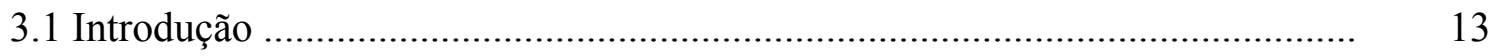

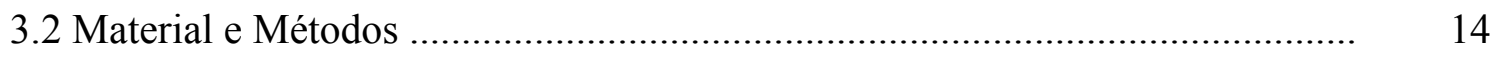

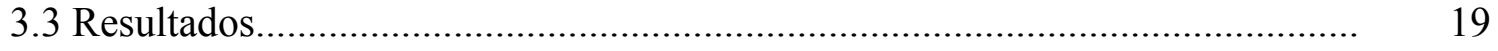

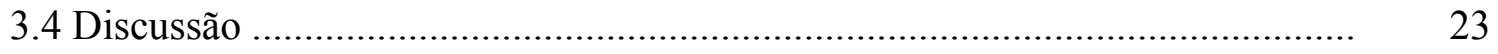

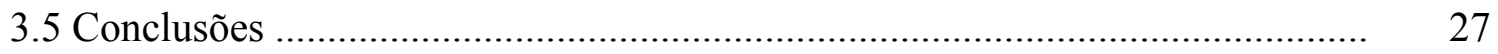


4 QUAL TESTEMUNHA NÃO MICORRIZADA UTILIZAR EM ESTUDOS DE INTERAÇÃO DE Phytophthora parasitica E FUNGOS MICORRÍZICOS ARBUSCULARES NATIVOS EM CITROS? ................................................. 28

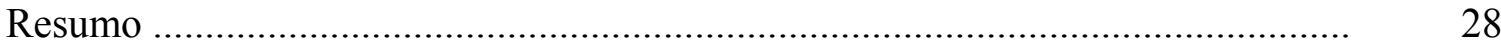

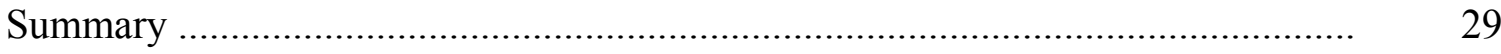

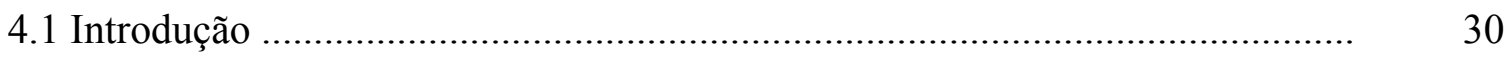

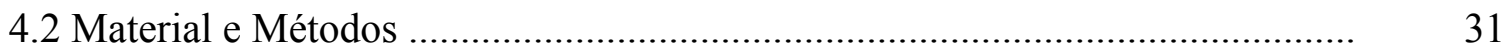

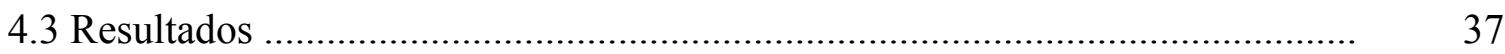

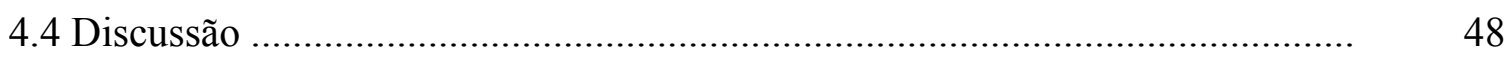

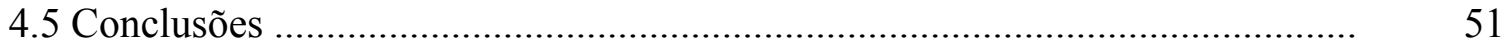

5 INTERAÇÃO DE Phytophthora parasitica E FUNGOS MICORRÍZICOS ARBUSCULARES NATIVOS EM CITROS: UM ESTUDO DE MICROCOSMO 52

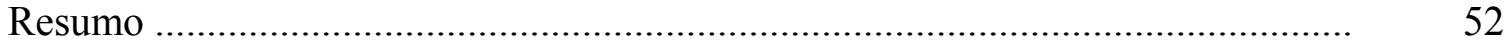

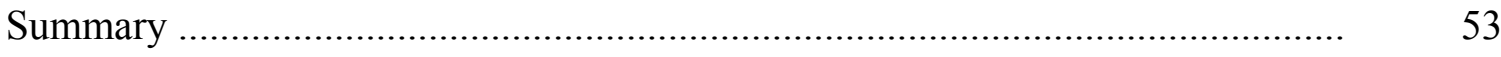

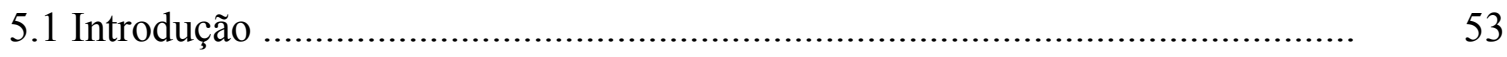

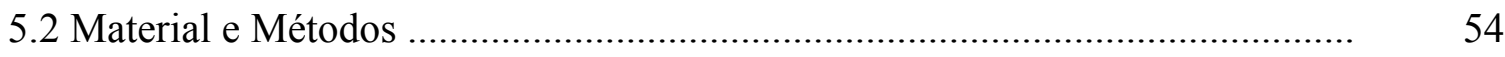

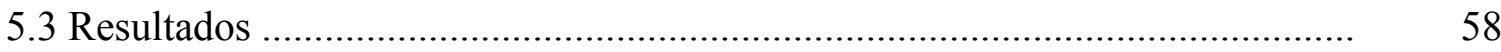

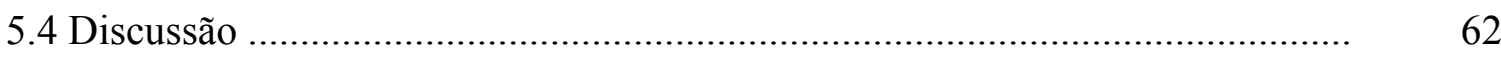

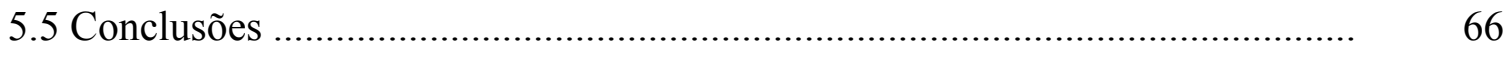

6 ATIVIDADE DE QUITINASE EM RAÍZES DE CITROS ASSOCIADAS A FUNGOS MICORRÍZICOS ARBUSCULARES NATIVOS ............................ 67

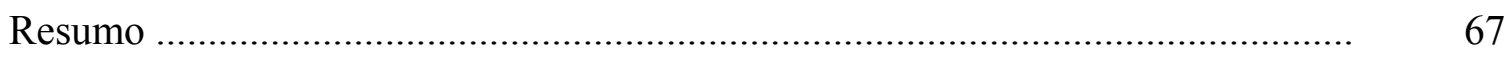

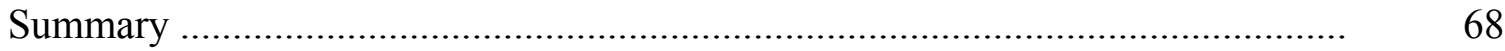

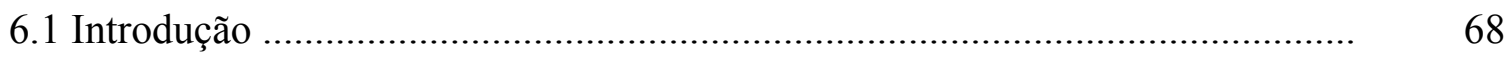

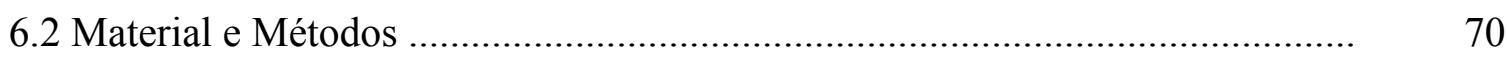

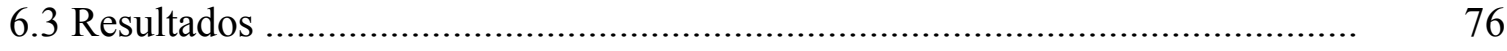

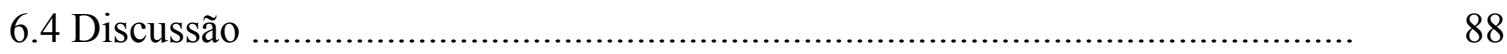

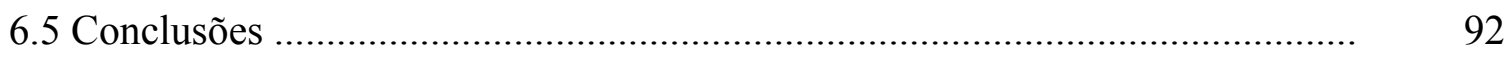

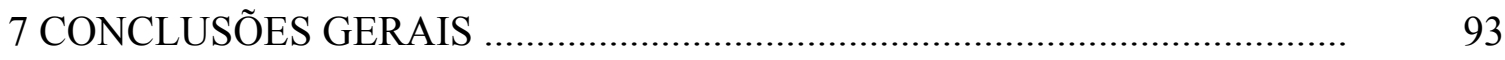

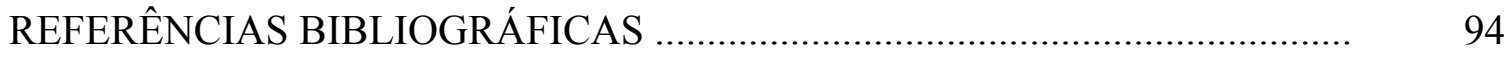




\title{
COMUNIDADES DE FUNGOS MICORRÍZICOS ARBUSCULARES NOS MANEJOS CONVENCIONAL E ORGÂNICO DE CITROS E SUAS INTERAÇÕES COM Phytophthora parasitica
}

\author{
Autora: SORAYA DE CARVALHO FRANÇA \\ Orientadora: Profa. Dra. ADRIANA PARADA DIAS DA SILVEIRA
}

\section{RESUMO}

Agricultores e técnicos envolvidos na citricultura orgânica procuram desenvolver sistemas de produção com maior atividade microbiana no solo. Dessa maneira, esperam obter benefícios dos processos que ocorrem no solo, entre eles, o controle natural de pragas e doenças. Porém, são poucos os estudos sobre a influência desse tipo de manejo sobre a microbiota do solo, em especial sobre os fungos micorrízicos arbusculares (FMAs) e o patógeno Phytophthora parasitica. Os objetivos dessa tese foram: avaliar a colonização micorrízica e conhecer a diversidade de FMAs nos sistemas de produção convencional e orgânico de citros; avaliar a aplicação de benomyl e da radiação $\gamma$ na obtenção de testemunhas não micorrizadas para estudo de interação de comunidade de FMAs nativos e $P$. parasitica; verificar a capacidade indutora de resistência local e sistêmica dos FMAs nativos a $P$. parasitica; estudar atividade da quitinase no sistema radicular de limão 'Cravo' colonizado por fungos micorrízicos nativos. Foram realizadas amostragens em dois sistemas de produção de citros em São Paulo, um convencional e um orgânico. A riqueza e a diversidade de espécies de FMAs foram maiores no manejo orgânico. No entanto, a porcentagem de colonização micorrízica nas plantas no campo 
não variou com o tipo de manejo. Em casa de vegetação, experimentos com plantas de limão 'Cravo' (Citrus limonia) mostraram que a radiação $\gamma$ foi mais adequada que a aplicação de benomyl na obtenção de testemunhas não micorrizadas para estudo de interação $P$. parasitica- FMAs nativos de agroecossistemas de produção de laranja. Também em casa de vegetação, foi realizado um experimento com raiz dividida de plantas de limão 'Cravo'. Não foi possível avaliar a capacidade indutora de resistência dos fungos micorrízicos arbusculares nativos porque não houve desenvolvimento da podridão de raízes nas plantas de limão 'Cravo' após a infestação com P. parasitica. Discute-se a interação de patógenos de raiz do solo natural e os FMAs nativos porque o solo natural dos sistemas de produção convencional e orgânico promoveram diferentes respostas de crescimento local e sistêmico das raízes das plantas micorrizadas. A atividade de quitinase foi igual nas raízes de plantas micorrizadas e não micorrrizadas cultivadas em solos dos sistemas de produção convencional e orgânico. Porém, a associação micorrízica aumentou localmente a proteína total nas raízes das plantas. 


\title{
ARBUSCULAR MYCORRHIZAL FUNGI COMMUNITIES IN CITRUS CONVENTIONAL AND ORGANIC FARMING AND THEIR INTERACTIONS \\ WITH Phytophthora parasitica
}

\author{
Author: SORAYA DE CARVALHO FRANÇA \\ Adviser: Prof. Dr. ADRIANA PARADA DIAS DA SILVEIRA
}

\section{SUMMARY}

Farmers and technicians involved with organic citriculture try to develop systems with high microbial activity in soil. In this way, they expect to obtain benefits from processes that occur in soil, as natural control of pests and diseases. However, there are few studies about the influence of this type of management on soil microbiota, specially on the arbuscular mycorrhizal fungi (AMF) and the pathogen Phytophthora parasitica. The objectives of this thesis were: to evaluate mycorrhizal colonization and diversity of AMF in citrus conventional and organic farming; to evaluate benomyl application and $\gamma$ radiation to obtain non-mycorrhizal controls for study of interaction between indigenous AMF and P. parasitica; to verify local and systemic capacity of indigenous AMF to induce resistance against $P$. parasitica; to study chitinase activity in roots of 'Rangpur' lime colonized by indigenous AMF. Samplings were carried out in two citrus systems in São Paulo, one conventional and one organic farming. The richness and the diversity of AMF species were higher in the organic farming. In greenhouse, experiments with 'Rangpur' lime (Citrus limonia) showed that $\gamma$ radiation was better than benomyl to obtain non-mycorrhizal control for studies of interaction between $P$. parasitica- 
indigenous AMF from orange agroecosystems. In greenhouse also, a split root experiment with 'Rangpur' lime was carried out. It was not possible to evaluate the indigenous AMF capacity to induce resistance because no root rot developed in 'Rangpur' lime plants after inoculation with $P$. parasitica. We discuss the interaction between root pathogens in natural soil and indigenous AMF because natural soil from conventional e organic farming promoted different local and systemic root growth responses in mycorrhizal plants. Chitinase activity was similar in roots of mycorrhizal and non-mycorrhizal plants grown in conventional and organic farming soils. However, mycorhizal association increased local protein content in roots. 


\section{INTRODUÇÃO}

Atualmente existe um grande interesse em promover sistemas de produção compatíveis com as tendências do desenvolvimento sustentável. Na citricultura brasileira, têm surgido experiências de produção baseadas nas normas internacionais da agricultura orgânica. Com esse tipo de manejo, espera-se estimular a atividade microbiana do solo, procurando assim, além de ativar processos de ciclagem de nutrientes, estabelecer o controle biológico natural de pragas e doenças. No entanto, ainda há poucos estudos avaliando o impacto do manejo incentivado na agricultura orgânica sobre a microbiota do solo.

Entre os diversos grupos de microrganismos do solo, os fungos micorrízicos arbusculares (FMAs) se destacam pelos múltiplos papéis que desempenham: estruturação do solo, nutrição das plantas e controle de patógenos habitantes do solo. Em campo, as raízes das plantas cítricas são colonizadas por FMAs nativos e, em experimentos com isolados em casa de vegetação, foi demonstrada a dependência das mudas à simbiose micorrízica. Além disso, interações de FMAs e Phytophthora parasitica já foram observadas em citros, apontando os fungos micorrízicos como potenciais agentes de controle biológico desse patógeno. Em plantas cítricas, P. parasitica causa podridão de raízes no viveiro e a gomose no campo.

Os FMAs podem diminuir a severidade de podridão de raízes nas plantas por meio de vários mecanismos de ação. Recentemente, em tomate, foi comprovado que a simbiose micorrízica pode inclusive induzir resistência a esse patógeno. Reações de defesa foram desencadeadas nas plantas de tomate e análises bioquímicas de raízes mostraram indução de novas isoformas da enzima hidrolítica quitinase, em resposta à micorrização e presença do patógeno. 
O manejo dos sistemas agrícolas atua de forma seletiva sobre os microrganismos do solo. A hipótese do presente trabalho é que o manejo orgânico promove o controle natural de $P$. parasitica em citros, devido em parte à comunidade de FMAs, maior e mais diversa que no manejo convencional. A razão para levantar essa hipótese é que no manejo orgânico não se utilizam fontes solúveis de fósforo e não se aplicam agrotóxicos. Essas práticas, comuns no manejo convencional, podem afetar a associação micorrízica. Surgiram as seguintes perguntas:

1. No manejo orgânico, a colonização micorrízica nas plantas cítricas é maior que no manejo convencional?

2. Há maior diversidade de espécies de FMAs no solo do sistema de produção orgânico que no solo do sistema convencional?

3. Qual a testemunha não micorrizada é mais apropriada para estudos de interação de comunidade de FMAs e P. parasitica em citros?

4. As comunidades de FMAs dos sistemas convencional e orgânico são capazes de diminuir, de forma local e sistêmica, a severidade de podridão de raízes causada por P. parasitica nas plantas de limão 'Cravo'?

5. Os FMAs nativos modificam a atividade de quitinase nas raízes de limão 'Cravo'? Portanto, os objetivos dessa tese foram:

- avaliar a colonização micorrízica nos sistemas de produção convencional e orgânico de citros;

- conhecer a diversidade de FMAs no solo dos sistemas de produção convencional e orgânico de citros;

- avaliar a aplicação de benomyl e da radiação $\gamma$ na obtenção de testemunhas não micorrizadas para estudo de interação de comunidade de FMAs nativos e P. parasitica; - verificar a capacidade indutora de resistência local e sistêmica dos FMAs nativos a $P$. parasitica;

- estudar atividade da quitinase no sistema radicular de limão 'Cravo' colonizado por fungos micorrízicos nativos. 


\section{REVISÃO DE LITERATURA}

\subsection{Manejo de problemas fitossanitários na citricultura brasileira}

\subsubsection{Situação atual}

O Fundo de Defesa da Citricultura (Fundecitrus) lista dez doenças e sete pragas como principais problemas fitossanitários que afetam a citricultura brasileira (Fundecitrus, 2004). Para solucionar esses problemas, pesquisas têm sido realizadas e recomendações de manejo integrado têm sido propostas (Rossetti, 1980; Müller, 1980; Gravena, 1980; Fundecitrus, 2004). No entanto, apesar dos esforços no desenvolvimento de diferentes estratégias de controle de doenças e pragas, o controle químico é ainda um método muito empregado no setor citrícola. Segundo Neves et al. (2001), de todas as culturas do Brasil, a laranja é a primeira em compra de agrotóxicos por hectare. Esses autores relatam que um estudo realizado em 1999 mostrou que foram vendidos para a citricultura US\$ 160 milhões no setor de defensivos, o que significou aproximadamente $5,5 \%$ das vendas do setor no país. Esse valor correspondeu a 38,9\% do total estimado para a movimentação "antes da porteira" na cadeia produtiva da citricultura e foi o mais alto dessa categoria que engloba defensivos, implementos, fertilizantes, mudas, tratores, irrigação e corretivos.

A situação atual do manejo dos problemas fitossanitários na citricultura brasileira, baseado principalmente no uso de agrotóxicos, não é atípica dentro do conjunto da agricultura no país. A agricultura brasileira sofreu um processo de inserção no sistema produtivo mundial, conhecido como "modernização", que a levou a uma alta dependência do uso de fertilizantes, agrotóxicos, sementes melhoradas e máquinas, que são, em grande parte, insumos importados (Aguiar, 1986). A agricultura intensiva em insumos externos (conhecida em inglês pela sigla HEIA) está provocando graves 
repercussões ecológicas, econômicas e sócio-políticas (Reijntjes et al., 1994). Esses problemas são sintomas da crise de um modelo de desenvolvimento e dos sistemas agrícolas convencionais (Altieri, 1995).

\subsubsection{Proposta da agricultura orgânica}

A agricultura sustentável se situa dentro de um novo conceito de desenvolvimento, o qual se pode lograr com a implementação de sistemas de produção que possuam uma base agroecológica. A agroecologia, como ciência, não se limita a promover a substituição de insumos químicos por biológicos, mas propõe uma abordagem holística no desenho de sistemas agrícolas complexos e diversificados, que funcionem sem necessidade de tantos insumos externos e sejam mais dependentes dos organismos dos próprios sistemas. Existem várias correntes de agricultura que adotam princípios da agroecologia, como a biológica, natural, orgânica, biodinâmica, permacultura, etc. (Altieri, 1995; Jesus, 1996). Entre elas, a agricultura orgânica tem sido a de maior expansão no mercado nacional e internacional e há normas elaboradas para serem seguidas pelos agricultores que desejem obter certificação de seus produtos. Tecnologias já desenvolvidas pela pesquisa, como o controle biológico de pragas e uso de adubos verdes, são promovidos na agricultura orgânica. No entanto, não se permite o uso de agrotóxicos e a adubação orgânica é complementada somente com certos fertilizantes minerais, como cinzas, pó de basalto e de granito, fosfatos de rocha e outros (Penteado, 2000). Em síntese, a agricultura orgânica é basicamente um sistema de produção, no qual está permitida a utilização de certos insumos, e não de outros. Portanto, esse tipo de agricultura perde seu enfoque agroecológico quando é dada maior ênfase à produção para mercados elitistas no exterior e à substituição de insumos, esquecendo-se de outros aspectos, tais como a otimização do uso de recursos naturais locais (biodiversidade, solo e água), diminuição do consumo de energia não renovável e fortalecimento do desenvolvimento local (Altieri, 1995; 2001; Freitas, 2003).

A preocupação com a fundamentação agroecológica parece fazer parte das propostas dos impulsores da agricultura orgânica no Brasil, inclusive da citricultura orgânica paulista (Peteado, 2000; D'Andréa, 2001). Espera-se que a maioria dos 
problemas fitossanitários possa ser resolvida preventivamente por meio do manejo, principalmente do solo, e não por aplicações intensivas de produtos de controle terapêutico permitidos por esse tipo de agricultura (Figura 1). D'Andréa (2001) e Deffune (2001) sugerem que diversos mecanismos de controle natural de pragas e doenças, inclusive a indução de resistência, podem ser estimulados quando se utiliza o manejo orgânico, diminuindo a necessidade de controles fitossanitários diretamente. O eixo central da proposta de manejo consiste em aproveitar a biomassa das plantas espontâneas e utilizar esterco somente na confecção de composto líquido (biofertilizante), que deve ser aplicado diluído no solo (sobre as ervas espontâneas roçadas) ou nas plantas, complementando-se com a utilização do pó de rocha MB-4 (Pinheiro \& Barreto, 1997; Amparo, 2001; D'Andréa, 2001).

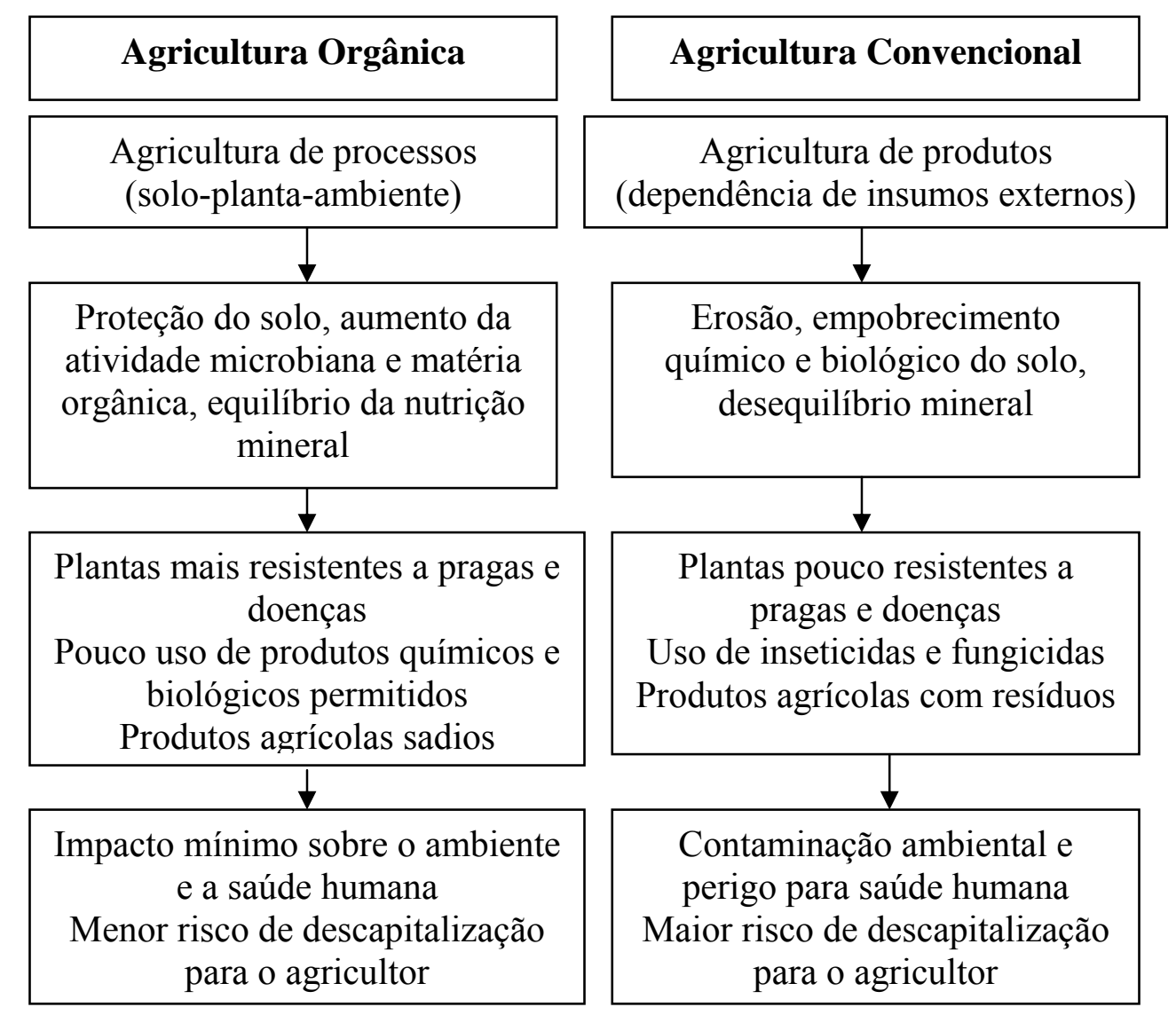

Figura 1 - Diferenças entre agricultura orgânica e convencional (adaptado de Penteado, 2001) 


\subsection{Phytophthora parasitica Dastur ( $\sin =$ P. nicotianae Breda de Haan)}

P. parasitica pertence à família Pythiaceae, ordem Peronosporales, classe Oomycetes, divisão Oomycota, reino Stramenopila (Alexopoulos et al., 1996). Apesar de não se encontrarem dentro do reino Fungi, os oomicetos são estudados juntamente com os fungos verdadeiros devido ao seu crescimento micelial. No entanto, várias diferenças existem entre esses grupos de microrganismos. Uma delas é a composição química da parede celular. Em Phytophthora, quitina está ausente, salvo poucas exceções, e estão presentes $\beta$-1,3 glucanos e celulose (Bartnicki-Garcia \& Wang, 1983).

Os esporângios de P. parasitica podem formar tubo germinativo (germinação direta) ou, por clivagem citoplasmática, produzir zoosporos que são liberados através de um poro (germinação indireta). Os zoosporos são esporos assexuais móveis, biflagelos e sem parede celular. Podem nadar a curtas distâncias e quando encontram o hospedeiro perdem os flagelos, encistam (formam parede celular) e emitem o tubo germinativo. Mesmo sem encontrar seu hospedeiro, os zoosporos podem encistar e permanecer no solo. Também no solo, se encontram os principais esporos de resistência de $P$. parasitica, os clamidosporos, e os esporos sexuais, os oosporos (Ribeiro, 1983; Feichtenberger, 2001)

Vários são os problemas causados por P. parasitica em citros, tanto em viveiro como em campo. Os danos começam na sementeira, onde o patógeno pode causar o tombamento de mudas. Ainda em viveiro, o patógeno pode provocar lesões em folhas, brotos novos e hastes. Porém, os problemas mais delicados são as podridões de raízes e radicelas que por não serem facilmente detectáveis, muitas vezes não são considerados e disseminam a doença para o campo. Nos pomares ocorrem, então, a podridão do pé e gomose em troncos e ramos (Feichtenberger, 2001). Segundo Fundecitrus (2004), a gomose constitui-se na mais importante doença fúngica em nosso país e continua em expansão no Estado de São Paulo devido ao uso de mudas contaminadas.

\subsection{Fungos micorrízicos arbusculares (FMAs)}

Os FMAs constituem um grupo de fungos pertencentes à divisão Glomeromycota que formam associações simbióticas com muitas espécies de plantas (INVAM, 2003; 
BEG, 2003). Dentro da ordem Glomales, estão agrupados atualmente em cinco famílias e sete gêneros (Quadro 1), num total de aproximadamente 150 espécies descritas (INVAM, 2003).

\begin{tabular}{|l|l|}
\hline \multicolumn{1}{|c|}{ Família } & \multicolumn{1}{c|}{ Gênero } \\
\hline Acaulosporaceae & Acaulospora e Entrophospora \\
\hline Archaeosporaceae & Archaeospora \\
\hline Glomaceae & Glomus \\
\hline Paraglomaceae & Paraglomus \\
\hline Gigasporaceae & Gigaspora e Scutellospora \\
\hline
\end{tabular}

Fonte: INVAM, 2003

Quadro 1 - Famílias e gêneros dos fungos micorrízicos arbusculares

Apesar da falta de especificidade entre planta e fungo micorrízico, pesquisas recentes têm trazido novas evidências para a diversidade de funções existentes entre diferentes pares de fungo e planta em simbiose (Smith, 2002). A função da associação micorrízica mais conhecida e estudada é o aumento da absorção de nutrientes pelas plantas, em especial do fósforo (Silveira, 1992). No entanto, pelo menos duas outras funções são atualmente atribuídas aos FMAs: a redução de doenças causadas por patógenos habitantes do solo e a formação de agregados de solo estáveis em água (Jefries et al., 2003).

Uma raiz pode ser colonizada concomitantemente por mais de uma espécie de fungo (Dood et al., 2000) e uma espécie de fungo pode apresentar tipos de crescimento distintos dentro das raízes quando associada a diferentes espécies de plantas (Smith \& Smith, 1997), ou velocidades de colonização diversas entre genótipos de uma mesma espécie de planta (Graham \& Eissenstat, 1994).

Os FMAs são de ocorrência generalizada nas plantas superiores, com exceção de alguns membros das famílias Brassicaceae, Amarantaceae, Comelinaceae, Juncaceae, Proteaceae, Poligonaceae, Cyperaceae e Chenopodiaceae. No entanto, as plantas apresentam diferentes níveis de dependência à simbiose, em função da disponibilidade 
de fósforo no solo, comparando-se a planta micorrizada com a não micorrizada, geralmente com base na produção de matéria seca (Moreira \& Siqueira, 2002). Como as plantas cítricas, em geral, respondem à micorrização até doses elevadas de $\mathrm{P}$, essas são consideradas altamente dependentes dos fungos micorrízicos.

Simbiose é um termo criado no século XIX para referir-se à vida em comum entre duas espécies. Embora muitas vezes empregado no sentido de relação benéfica para ambas as espécies envolvidas, o conceito considerado no presente trabalho engloba não só as relações de mutualismo, como de agonismo (parasitismo e predação) e de comensalismo (Lewis, 1985; Figura 2).

Apesar de as micorrizas serem consideradas exemplos clássicos de mutualismo, nem sempre essas relações se comportam dessa maneira. Para os FMAs, que são fungos biotróficos obrigatórios, sempre há benefícios na relação. No entanto, as respostas das plantas à colonização micorrízica podem ser positivas, neutras e negativas (Johnson et al., 1997). O saldo líquido do custo-benefício para as plantas pode variar com o genótipo do hospedeiro, com a fase do ciclo de vida e com a presença ou ausência de recursos (por exemplo, nutrientes), pragas e patógenos (Clay, 1992). Portanto, as relações entre FMAs e plantas nem sempre se enquadram dentro do segmento do mutualismo, mas se movem nos segmentos que compõem a continuidade da simbiose.

Um aspecto importante na análise da resposta das plantas à simbiose é a variável escolhida para medir os benefícios da associação. Enquanto em sistemas naturais, a sobrevivência e a fecundidade são bons indicadores do sucesso reprodutivo, nos sistemas agrícolas, a biomassa e, ou, a produção de frutos e sementes são as variáveis de resposta que mais interessam (Johnson et al., 1997). Os custos, geralmente, são expressos em termos de compostos fotossintetizados gastos com a manutenção dos fungos no sistema radicular das plantas (Koch \& Johnson, 1984; Peng et al., 1993; Johnson et al., 1997).

Segundo Kiers et al. (2002), o interesse na utilização das simbioses na agricultura tem crescido, porém pouco ainda se sabe como as diferentes práticas agrícolas poderiam estar selecionando simbiontes com comportamentos mais parasíticos ou mutualistas nos sistemas de produção. 


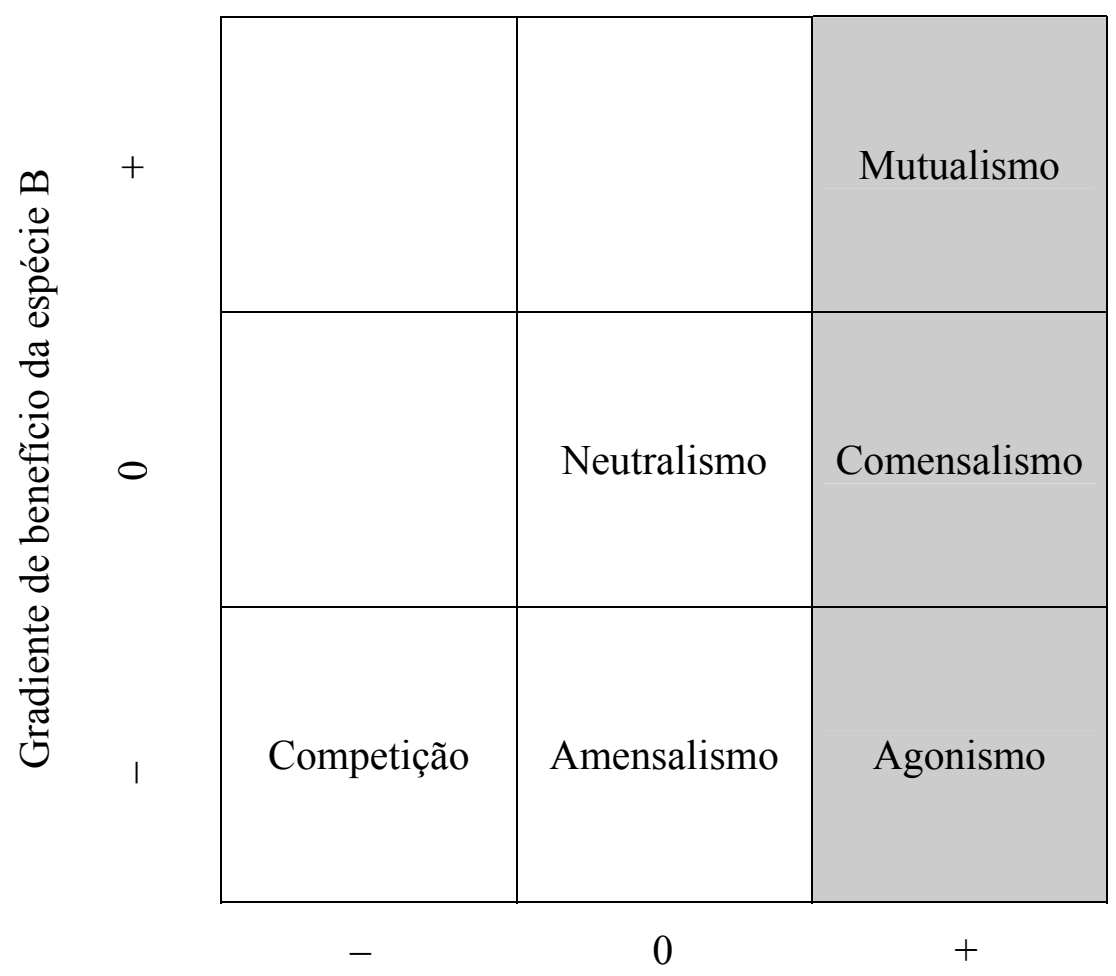

Gradiente de benefício da espécie A

Figura 2 - Interações entre espécies. A simbiose engloba agonismo, comensalismo e mutualismo (área cinza) (Adaptado de Lewis, 1985 e Johnson et al., 1997)

\subsection{Interações de plantas, FMAs e P. parasitica}

Os FMAs, como componentes importantes da microbiota do solo, interagem com outros microrganismos, influenciando a qualidade do solo. Uma das contribuições das associações micorrízicas é a redução de doenças causadas por fungos fitopatogênicos habitantes do solo, tais como Phytophthora, Gaeumannomyces, Fusarium, Chalara (Thielaviopses), Pythium, Rhizoctonia, Sclerotium, Verticillium e Aphanomyces (AzcónAguilar \& Barea, 1996; Jeffries et al., 2003). No entanto, a capacidade da simbiose planta-FMA de exercer o controle biológico com sucesso não é igual para todos hospedeiros, fungos micorrízicos e patógenos. Além disso, a proteção é regulada pelo 
solo e por outras condições ambientais. Portanto, as interações de FMAs e patógenos variam com o sistema de produção (Azcón-Aguilar \& Barea, 1996).

Interações de FMAs e $P$. parasitica já foram constatadas em plantas de tomate e citros. Em tomate (Lycopersicum esculentum), cultivar 'Earlymech', o fungo micorrízico Glomus mosseae (BEG 12) reduziu a severidade de podridão de raízes causada por $P$. parasitica numa série de estudos (Pozo et al., 1996; Trotta et al., 1996; Cordier et al., 1996; Cordier et al., 1998; Fusconi et al., 1999; Pozo et al., 2002), enquanto a espécie Glomus intraradices (BEG 72) não afetou a severidade da doença (Pozo et al., 2002). Plantas de laranja doce (Citrus sinensis), cultivar 'Pineapple', associadas a certos isolados de Glomus fasciculatum (185) e G. mosseae (614) apresentaram maior porcentagem de raízes sadias na presença de $P$. parasitica que plantas não micorrizadas, porém esse efeito protetor não foi verificado com alguns isolados de G. fasciculatum (92 e 103) e com outras espécies de fungos micorrízicos testadas (Davis \& Menge, 1980; 1981). Graham (1988) e Agnani (2002) também lograram redução da podridão de raízes com isolados de $G$. intraradices em simbiose com plantas de laranja doce e de limão 'Cravo' (Citrus limonia), respectivamente (primeiro autor não especificou a cultivar nem $\mathrm{o}$ isolado e o segundo, o isolado). Entre vários FMAs testados em Poncirus trifoliata $\mathrm{x}$ Citrus sinensis, apenas o isolado de G. mosseae (614) controlou a doença (Davis \& Menge, 1981).

Apesar de os resultados indicarem os FMAs como potenciais agentes de controle biológico de $P$. parasitica em citros, os mecanismos de ação envolvidos ainda não estão esclarecidos. Em geral, devido à grande dependência das plantas cítricas a micorriza, as plantas em simbiose possuem desenvolvimento e teor de fósforo foliar superiores às plantas sem micorriza. Além disso, o patógeno pode reduzir a colonização radicular dos fungos micorrízicos e, conseqüentemente, o $\mathrm{P}$ foliar nas plantas micorrizadas, resultando em maior redução relativa de matéria seca dessas plantas que das não micorrizadas. Nesse caso, as reduções na severidade de podridão de raízes são interpretadas como tolerância do hospedeiro em simbiose devido à melhor nutrição mineral e não como resistência (Davis \& Menge, 1980; 1981; Graham, 1988). No entanto, em alguns casos, os fungos micorrízicos parecem aumentar a resistência das plantas. Por exemplo, quando 
a situação é igual ao descrito anteriormente, porém a maior redução relativa da matéria seca das plantas micorrizadas ocorre sem que o patógeno afete a colonização micorrízica e o P foliar (Agnani, 2002). Outra situação que indica o envolvimento da indução de resistência é a seguinte: a combinação cultivar- FMA resulta em plantas de desenvolvimento e $\mathrm{P}$ foliar semelhantes aos controles não micorrizados, o patógeno afeta a colonização micorrízica, mas não o $\mathrm{P}$ foliar e as plantas micorrizadas apresentam maior porcentagem de raízes sadias e menor redução relativa de matéria seca que os controles (Davis \& Menge, 1981).

Estudos mais detalhados sobre os mecanismos de ação que participam da interação fungos micorrízicos- $P$. parasitica têm sido realizados em tomate, inclusive já foi comprovado o mecanismo de indução de resistência (Cordier et al., 1998). Entre as respostas de defesa das plantas ativadas durante a interação com esses microrganismos foi constatada a indução das enzimas hidrolíticas quitinases, quitosanases e $\beta-1,3-$ glucanases (Pozo et al., 2002). Esses estudos foram desenvolvidos em condições ambientais controladas e com apenas uma combinação de cultivar de tomate e espécie de fungo micorrízico. Portanto, pouco ainda se pode inferir sobre as reações de defesa das plantas associadas a comunidades de FMAs em condições ambientais variáveis, como naturalmente ocorre nos sistemas de produção. 


\section{ATIVIDADE MICROBIANA E DIVERSIDADE DE FUNGOS MICORRÍZICOS ARBUSCULARES EM AGROECOSSISTEMAS CONVENCIONAL E ORGÂNICO DE CITROS}

\section{Resumo}

Impulsores da citricultura orgânica procuram desenvolver sistemas de produção com maior atividade microbiana no solo e, portanto, com maior potencial de controle natural de pragas e doenças. Porém, pouco se conhece sobre a influência do manejo dos pomares de citros sobre a microbiota do solo. Foram estudados alguns aspectos da atividade microbiana do solo e a diversidade de fungos micorrízicos arbusculares (FMAs) em dois sistemas de produção de laranja, um convencional e um orgânico. O solo do sistema orgânico apresentou maior carbono da biomassa microbiana, maior respiração e menor quociente metabólico (respiração/biomassa) que o solo do sistema convencional. Quanto à atividade de celulase, não houve diferença entre os dois sistemas. A riqueza e a diversidade de espécies de FMAs foram maiores no manejo orgânico.

\section{MICROBIAL ACTIVITY AND ARBUSCULAR MYCORRHIZAL FUNGI DIVERSITY IN CONVENTIONAL AND ORGANIC CITRUS AGROECOSYSTEMS}

\section{Summary}

Citrus organic farming promoters try to develop agroecosystems with high soil microbial activity and hence high potential of pest and disease natural control. However, 
we know little about the influence of citrus orchards management on soil microorganisms. We studied some aspects of soil microbial activity and arbuscular mycorrhizal fungi (AMF) diversity in two orange agroecosystems, a conventional and an organic farming one. The organic farming soil showed higher microbial biomass $\mathrm{C}$ and respiration and lower $\mathrm{qCO}_{2}$ (respiration/biomass) than the conventional farming soil. There was no difference in cellulase activity between the agroecosystems soils. Richness and diversity of AMF species were higher in the organic management.

\subsection{Introdução}

É crescente o interesse dos consumidores por produtos agrícolas oriundos de sistemas de produção sustentáveis. Esse novo modelo de produção requer um enfoque integral da fertilidade do solo (química, física e biológica) e da sua relação com problemas fitossanitários do cultivo. O manejo do solo é considerado o principal fator capaz de criar condições de controle natural de pragas e doenças nos cultivos.

O Estado de São Paulo é o responsável pela produção da laranja de $98 \%$ do suco que o Brasil exporta (Fundecitrus, 2004). A maioria dos produtores utiliza o manejo convencional, no qual a ênfase é a alta produtividade do cultivo no curto prazo com uso de insumos como os fertilizantes químicos e agrotóxicos. Os impulsores da citricultura orgânica nesse Estado têm proposto um manejo com base na elaboração e aplicação de biofertilizantes líquidos e farinhas de rocha nos pomares para o aumento da produção de biomassa vegetal. Com estas práticas, os agricultores procuram estimular a microbiota do solo e desenvolver agroecossistemas produtivos com base nos processos naturais.

Em geral, maior atividade microbiana tem sido vinculada ao controle de patógenos habitantes do solo (Rodríguez-Kábana \& Calvet, 1994). Antibiose, competição e parasitismo podem afetar o desenvolvimento dos patógenos (Handelsman \& Stabb, 1996). Além disso, os Oomicetos, que possuem celulose na parede celular (Bartnicki-Garcia \& Wang, 1983), podem sofrer a ação das enzimas celulolíticas liberadas no solo por fungos saprofíticos (Downer et al., 2001). 
Os fungos micorrízicos arbusculares (FMAs) formam a simbiose microbiana mais importante para a maioria das plantas, propiciando vários benefícios a estas, entre eles, a proteção contra patógenos de raiz (Azcón-Aguilar \& Barea, 1996; Jeffries et al., 2003). Em condições de casa de vegetação, já foi demonstrado que as plantas cítricas associadas a alguns isolados de FMAs podem apresentar menor severidade de podridão de raízes causada por Phytophthora parasitica que plantas não micorrizadas (Davis \& Menge, 1980; 1981; Agnani, 2002).

Pouco se conhece sobre a influência do manejo dos pomares de citros sobre a microbiota do solo e, conseqüentemente, poucas hipóteses sobre sua relação com importantes patógenos habitantes do solo, como P. parasitica, podem ser levantadas para futuros trabalhos. Nesse contexto, realizou-se o presente estudo com o objetivo de conhecer alguns aspectos da atividade microbiana do solo, a colonização micorrízica e a diversidade de FMAS em dois sistemas de manejo de plantas cítricas: convencional e orgânico.

\subsection{Material e Métodos}

Aproximadamente aos $45 \mathrm{Km}$ de Piracicaba na via para Anhembi, SP, foram selecionadas duas propriedades vizinhas que possuem cultivos de laranja 'Pêra' (Citrus sinensis) enxertada em limão 'Cravo' (Citrus limonia) de idades similares (10-12 anos) plantados no mesmo tipo de solo (Neossolo Quartzarênico). O aspecto mais importante que as difere é o tipo de manejo do sistema de produção. Uma segue o manejo do tipo convencional e a outra o manejo orgânico.

Em março de 2002, amostragens de solo de cada propriedade foram realizadas da seguinte maneira: quatro pontos/árvore, de 0 a $20 \mathrm{~cm}$ de profundidade e distantes cerca de $60 \mathrm{~cm}$ do tronco, em torno de 15 árvores (uma árvore a cada duas linhas do lote). Amostras de cada três árvores foram misturadas, formando cinco amostras compostas por sistema de produção, que foram passadas em peneira de $2 \mathrm{~mm}$ e utilizadas para as análises da atividade microbiana. Para o estudo de colonização radicular e diversidade de FMAs, amostras de 15 e oito árvores foram consideradas, respectivamente. A análise 
da fertilidade do solo foi realizada no Laboratório de Análise de Solo e Planta do IAC em Campinas, SP, de uma amostra composta única de cada sistema de produção (Tabela1).

Tabela 1. Análise de fertilidade do solo dos sistemas de produção de plantas cítricas, orgânico e convencional

\begin{tabular}{|c|c|c|c|c|}
\hline \multicolumn{3}{|c|}{ Determinações } & \multicolumn{2}{|c|}{ Sistemas de produção } \\
\hline Sigla & Descrição & Unidade & Orgânico & Convencional \\
\hline M.O. & Mat. Orgânica & $\mathrm{g} \mathrm{m}^{-3}$ & 15 & 12 \\
\hline $\mathrm{pH}$ & Solução $\mathrm{CaCl}_{2}$ & & 6,3 & 5,5 \\
\hline $\mathrm{P}$ & Fósforo Resina & $\mathrm{mg} \mathrm{dm}^{-3}$ & 50 & 43 \\
\hline K & Potássio & $\mathrm{mmol}_{\mathrm{c}} \mathrm{dm}^{-3}$ & 0,3 & 1,0 \\
\hline $\mathrm{Ca}$ & Cálcio & $\mathrm{mmol}_{\mathrm{c}} \mathrm{dm}^{-3}$ & 59 & 26 \\
\hline $\mathrm{Mg}$ & Magnésio & $\mathrm{mmol}_{\mathrm{c}} \mathrm{dm}^{-3}$ & 23 & 12 \\
\hline $\mathrm{H}+\mathrm{Al}$ & Ac. Potencial & $\mathrm{mmol}_{\mathrm{c}} \mathrm{dm}^{-3}$ & 8 & 16 \\
\hline S.B. & Soma de Bases & $\mathrm{mmol}_{\mathrm{c}} \mathrm{dm}^{-3}$ & 82,3 & 39,0 \\
\hline CTC & Cap. Troca Cat. & $\mathrm{mmol}_{\mathrm{c}} \mathrm{dm}^{-3}$ & 90,1 & 55,4 \\
\hline V & Sat. Bases & $\%$ & 91 & 70 \\
\hline B & Boro & $\mathrm{mg} \mathrm{dm}{ }^{-3}$ & 0,12 & 0,14 \\
\hline $\mathrm{Cu}$ & Cobre & $\mathrm{mg} \mathrm{dm}^{-3}$ & 2,9 & 6,3 \\
\hline $\mathrm{Fe}$ & Ferro & $\mathrm{mg} \mathrm{dm}^{-3}$ & 12 & 41 \\
\hline Mn & Manganês & $\mathrm{mg} \mathrm{dm}^{-3}$ & 10,0 & 4,4 \\
\hline $\mathrm{Zn}$ & Zinco & $\mathrm{mg} \mathrm{dm}^{-3}$ & 7,3 & 2,2 \\
\hline
\end{tabular}

Em maio de 2003 foi realizada outra amostragem seguindo o mesmo procedimento já descrito. Para retirada de volume constante por amostra (aproximadamente $300 \mathrm{~mL}$ ), foram utilizados tubos de PVC cortados cada $20 \mathrm{~cm}$ de comprimento com bordas afiadas. Posteriormente, o solo foi passado em peneira de 2 $\mathrm{mm}$, o volume medido e as raízes retidas foram pesadas. Também foram realizadas análises de atividade microbiana nesta época de coleta. 


\section{Atividade Microbiana}

O carbono da biomassa microbiana foi determinado com base no método de fumigação-extração (Vance et al., 1987). De cada amostra, $20 \mathrm{~g}$ de solo foram fumigadas com clorofórmio por $24 \mathrm{~h}$ no escuro, enquanto outros $20 \mathrm{~g}$ de solo foram mantidos em sua condição natural (não fumigada). Posteriormente, de ambas as subamostras realizou-se a extração com $80 \mathrm{~mL}$ de $\mathrm{K}_{2} \mathrm{SO}_{4} 0,5 \mathrm{M}$ por $1 \mathrm{~h}$ em agitação contínua. Após $1 \mathrm{~h}$ de decantação, as sub-amostras foram filtradas em papel filtro $\mathrm{n}^{\circ} 42$. Em um tubo digestor foram colocados $8 \mathrm{~mL}$ de extrato de solo de cada sub-amostra fumigada e não fumigada, $2 \mathrm{~mL}$ de $\mathrm{K}_{2} \mathrm{Cr}_{2} \mathrm{O}_{7} 0,4 \mathrm{~N}, 10 \mathrm{~mL}$ de $\mathrm{H}_{2} \mathrm{SO}_{4}$ e $5 \mathrm{~mL}$ de $\mathrm{H}_{3} \mathrm{PO}_{4}$ concentrados. Foi realizada a digestão em banho-maria $50{ }^{\circ} \mathrm{C}$ por $1 \mathrm{~h}$. Depois de esfriado, cada tubo recebeu $25 \mathrm{~mL}$ de água destilada e sete gotas de indicador ferroína $(1,485 \mathrm{~g}$ de $O$-fenantrolina monohidratada e $0,695 \mathrm{~g}$ de sulfato ferroso heptahidratado em $100 \mathrm{~mL}$ de água destilada) e foi realizada a titulação com sulfato ferroso amoniacal, previamente padronizado $(0,0337 \mathrm{~N})$, até que a solução apresentava coloração avermelhada. Assim, foi estimado o excedente de dicromato e, por diferença, obtida a quantidade utilizada na oxidação do carbono da amostra. O carbono da biomassa foi calculado multiplicando a diferença entre carbono extraído do solo fumigado e não fumigado pelo fator 2,64.

Para medir a respiração basal, $50 \mathrm{~g}$ de solo de cada amostra com $60 \%$ de sua capacidade máxima de retenção de água foram colocados dentro de um recipiente de vidro, que foi fechado com um filme plástico e deixado incubar por cinco dias a $25{ }^{\circ} \mathrm{C}$. Após esse período, foi inserido um erlenmeyer contendo $10 \mathrm{~mL}$ de $\mathrm{NaOH} 0,1 \mathrm{~N}$. O recipiente de vidro foi fechado hermeticamente e mantido sete dias em incubação a $25^{\circ}$ C. Em seguida, o erlenmeyer foi retirado do recipiente de vidro e recebeu $1 \mathrm{~mL} \mathrm{de} \mathrm{BaCl}_{2}$ $50 \%$ e duas gotas de fenolftaleína $(0,1 \mathrm{~g}$ de fenolftaleína, $60 \mathrm{~mL}$ de álcool etílico, água destilada para completar $100 \mathrm{~mL}$ de solução). Foi realizada titulação com $\mathrm{HCl} 0,1 \mathrm{~N}$ até a mudança de cor de rosa para incolor, o que correspondeu ao excesso de $\mathrm{NaOH}$ na solução, ou seja a quantidade que não reagiu com o $\mathrm{CO}_{2}$ liberado dentro do recipiente. Finalmente, a quantidade de $\mathrm{CO}_{2}$ do branco foi subtraído da obtida da amostra e esse 
valor dividido pelo peso do solo seco e o número de dias da última incubação. Foram feitas três repetições por amostra e três brancos.

A atividade da celulase total (endoglucanase, exoglucanase e $\beta$-glucosidase) foi determinada utilizando-se Avicel como substrato (Alef \& Nannipieri, 1995). Os reagentes e soluções utilizadas estão listadas a seguir:

- Tampão de acetato de sódio (0,1 M, pH 5,5, 0,2\% de azida de sódio);

- Avicel (Merck);

- Solução 1: $15 \mathrm{~g}$ de Tartarato de $\mathrm{Na}-\mathrm{K}$ e $30 \mathrm{~g}$ de $\mathrm{Na}_{2} \mathrm{CO}_{3}$ dissolvidos em $300 \mathrm{~mL}$ de água destilada, e acrescentado posteriormente $20 \mathrm{~g}$ de $\mathrm{NaHCO}_{3}$;

- Solução 2: $180 \mathrm{~g}$ de $\mathrm{Na}_{2} \mathrm{SO}_{4}$ dissolvidos em $500 \mathrm{~mL}$ de água destilada (solução foi fervida para retirada do ar e depois deixada esfriar a temperatura ambiente);

- Solução 3: soluções 1 e 2 misturadas e diluídas para 1 L com água destilada;

- Solução 4: 5 g de $\mathrm{CuSO}_{4} .5 \mathrm{H}_{2} \mathrm{O}$ e $45 \mathrm{~g}$ de $\mathrm{Na}_{2} \mathrm{SO}_{4}$ dissolvidos em água destilada até completar $250 \mathrm{~mL}$;

- Solução 5: um volume da solução 3 e um volume da solução 4 misturados no momento de uso;

- Solução de Arsenato-Molibdato: com agitação constante, $21 \mathrm{~mL}$ de $\mathrm{H}_{2} \mathrm{SO}_{4}$ concentrado foi acrescentado à solução de $25 \mathrm{~g}$ de Molibdato de amônia dissolvido em $450 \mathrm{~mL}$ de água destilada. Depois $25 \mathrm{~mL}$ de uma solução de $3 \mathrm{~g}$ de $\mathrm{Na}_{2} \mathrm{HAsO}_{4} .7 \mathrm{H}_{2} \mathrm{O}$ em $25 \mathrm{~mL}$ de água foram acrescentados e misturados vigorosamente na solução. A solução foi guardada em frasco escuro depois de descansar 2 dias a $37{ }^{\circ} \mathrm{C}$. Um volume desta solução foi diluído em dois volumes de $\mathrm{H}_{2} \mathrm{SO}_{4}(0,75 \mathrm{M})$ no momento de uso;

- Solução padrão de glicose monohidratada: 79 mg em 1 L de água destilada.

Foi seguido o procedimento descrito em Alef \& Nannipieri (1995), com algumas modificações. Tubos de ensaio contendo $1 \mathrm{~g}$ de solo úmido, $5 \mathrm{~mL}$ de tampão de acetato e $0,5 \mathrm{~g}$ de Avicel foram cobertos com papel alumínio e incubados por $24 \mathrm{~h} \mathrm{a} 40{ }^{\circ} \mathrm{C}$, em banho maria. Os tubos foram agitados algumas vezes durante esse período. A reação foi parada por centrifugação $(2500 \mathrm{~g}$ por $10 \mathrm{~min})$. Controles foram feitos, adicionando Avicel depois da incubação e antes da centrifugação. Foram pipetados $3 \mathrm{~mL}$ do sobrenadante para novos tubos e acrescentados $3 \mathrm{~mL}$ da solução 5 . Os tubos foram 
fechados com bolas de gude e levados à banho maria fervendo por $20 \mathrm{~min}$. Depois de esfriados, foram adicionados $3 \mathrm{~mL}$ da solução de arsenato-molibdato diluída e misturado. Finalmente, a mistura foi diluída em $9 \mathrm{~mL}$ de água destilada e medida a transmitância a $520 \mathrm{~nm}$ no colorímetro. A curva de glicose foi obtida pipetando 0,$1 ; 0,3$; 0,$5 ; 0,7 ; 0,9 ; 1,1 ; 1,3 ; 1,5 ; 1,7$ e $1,9 \mathrm{~mL}$ da solução padrão de glicose e completando com água destilada para $10 \mathrm{~mL}$. Todas as leituras foram feitas em duplicata.

\section{Fungos Micorrízicos Arbusculares}

Para a determinação da colonização radicular por FMAs, as raízes das amostras de campo foram lavadas e guardadas em álcool 50\%. Posteriormente, foram clarificadas em $\mathrm{KOH} 10 \%$ em banho-maria fervendo por $15 \mathrm{~min}$, lavadas e colocadas em uma solução a 5\% de tinta de caneta (Parker, preta) e vinagre branco de cozinha puro (4\% de ácido acético) por 3-4 minutos em banho-maria fervendo (Vierheilig et al., 1998). Depois de lavados em água corrente, 30 segmentos de $1 \mathrm{~cm}$ de raiz colorida por amostra foram montados em lâminas e observados em microscópio (Giovannetti \& Mosse, 1980).

Os esporos de FMAs foram extraídos de $50 \mathrm{~mL}$ de solo de cada amostra pelo método do peneiramento úmido (Gerdemann \& Nicholson, 1963). Aqueles retidos na peneira de $45 \mu \mathrm{m}$ foram recolhidos e centrifugados em solução de sacarose $70 \%$. Depois da centrifugação, os esporos foram lavados em água corrente na peneira de $45 \mu \mathrm{m}$ para retirada da sacarose e guardados em água destilada no congelador até o momento da triagem e preparação das lâminas. Em estereoscópio, os esporos foram separados em grupos de acordo com aspectos morfológicos. As lâminas foram montadas em álcool polivinil-lacto-glicerol (PVLG) e PVLG com reagente de Melzer e as identificações realizadas com base nas descrições do INVAM (INVAM, 2003). Com os dados obtidos, foram calculados a riqueza e diversidade de espécies (índice de Whittaker) e a concentração da dominância (índice de Simpson), conforme descrito em Cuenca \& Meneses (1996). 


\section{Análise estatística}

Para análise estatística, o teste $\mathrm{t}$ foi aplicado para comparações entre duas médias.

\subsection{Resultados}

\section{Atividade Microbiana}

Em março de 2002, o solo do sistema orgânico apresentou maior carbono da biomassa microbiana e atividade de respiração que o solo do sistema convencional. Porém, o quociente metabólico (respiração/biomassa) do sistema orgânico foi maior que o obtido para o sistema convencional (Tabela 2). Quanto à atividade de celulase, não houve diferença significativa entre os dois sistemas (Tabela 3).

Em maio de 2003, as diferenças entre os dois sistemas foram menores, mas ainda significativas, exceto para o carbono da biomassa (Tabela 2).

Tabela 2. Respiração basal, carbono da biomassa e quociente metabólico $\left(\mathrm{qCO}_{2}\right)$ do solo dos sistemas de produção de plantas cítricas convencional e orgânico em duas épocas de amostragem

\begin{tabular}{ccccc}
\hline Atividade microbiana & \multicolumn{2}{c}{ março 2002 } & \multicolumn{2}{c}{ maio 2003 } \\
& Convencional & Orgânico & Convencional & Orgânico \\
& & & & \\
\hline Respiração basal & $13,6 \pm 1,0$ & $35,0 \pm 1,6 *$ & $35,6 \pm 0,7$ & $47,1 \pm 3,7 *$ \\
$\left(\mu \mathrm{g} \mathrm{CO} \mathrm{g}^{-1}\right.$ solo dia $\left.{ }^{-1}\right)$ & & & & \\
Biomassa $-\mathrm{C}$ & $213,8 \pm 15,8$ & $281,3 \pm 22,0 *$ & $231,4 \pm 17,7$ & $251,3 \pm 26,8 \mathrm{NS}$ \\
$\left(\mu \mathrm{g} \mathrm{C} \mathrm{g}\right.$ g $^{-1}$ solo $)$ & & & & \\
$\mathrm{qCO}_{2}$ & $0,06 \pm 0,003$ & $0,12 \pm 0,01 *$ & $0,15 \pm 0,008$ & $0,18 \pm 0,008 *$
\end{tabular}

Nas linhas, dentro de cada época de amostragem, (*) indica que há diferença entre médias $(\mathrm{P} \leq 0,05)$ pelo teste t. Apresentação: média \pm erro padrão. Número de amostras compostas por sistema $=5$ 
Tabela 3. Atividade da celulase no solo de dois sistemas de produção de plantas cítricas: convencional e orgânico

\begin{tabular}{|c|c|}
\hline Sistemas de Produção & 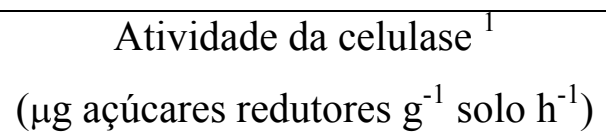 \\
\hline Convencional & $3,8 \pm 1,3 \mathrm{~ns}$ \\
\hline Orgânico & $3,1 \pm 0,8$ \\
\hline
\end{tabular}

\section{Fungos Micorrízicos Arbusculares}

A classe estrutural das micorrizas observadas nas plantas cítricas se identifica com o tipo Arum, conforme descrito em Smith \& Smith (1997). Foram observadas hifas intracelulares em algumas regiões das raízes e extenso crescimento de hifas intercelulares com formação de arbúsculos em células adjacentes. Em vários segmentos, houve formação de vesículas, indicando a presença de fungos pertencentes às famílias da subordem Glomineae. A colonização radicular foi maior que $90 \%$ nos dois tipos de manejo, porém a quantidade de raiz obtida nas amostras do sistema orgânico foi cerca de três vezes maior que a do sistema convencional (Tabela 4). O número de esporos por 50 $\mathrm{mL}$ de solo variou de 1 a 268 , com média 64,3 no sistema convencional e de 13 a 875 , com média 154,0 no sistema orgânico.

Tabela 4. Massa da matéria fresca de raiz de plantas cítricas nos sistemas de produção convencional e orgânico

\begin{tabular}{lc}
\hline \multicolumn{1}{c}{ Sistemas de Produção } & Massa da matéria fresca de raiz \\
& $\mathrm{g} \mathrm{L}^{-1}$ solo \\
\hline Convencional & $4,3 \pm 0,4$ \\
Orgânico & $14,5 \pm 5,3 *$ \\
\hline
\end{tabular}

(*) indica que há diferença entre médias $(\mathrm{P} \leq 0,05)$ pelo teste t. Apresentação: média \pm erro padrão. Número de amostras $=15$ 
Tanto no sistema de produção convencional como no orgânico, o maior número de espécies encontradas pertence ao gênero Glomus (Tabela 5). Considerando os dois sistemas em conjunto, 25 espécies de fungos micorrízicos foram identificadas, sendo nove comuns a ambos (Tabela 6). As espécies Glomus macrocarpum e Glomus microcarpum foram aquelas de ocorrência mais freqüente no sistema orgânico e convencional, respectivamente. A espécie comum aos dois sistemas de produção que ocorreu com maior freqüência em ambos foi Glomus fasciculatum (Tabela 6). No manejo orgânico, o número total de espécies, a riqueza e a diversidade de espécies foram maiores e a esporulação menos concentrada dentro de algumas espécies que no convencional (Tabelas 6 e 7).

Tabela 5. Número de espécies de FMAs dentro de cada gênero em dois sistemas de produção de plantas cítricas: convencional e orgânico

\begin{tabular}{lcc}
\hline & \multicolumn{2}{c}{ Número de espécies } \\
Gênero & Convencional & Orgânico \\
\hline Glomus & 7 & 10 \\
Acaulospora & 2 & 6 \\
Entrophospora & 0 & 1 \\
Archaeospora & 1 & 0 \\
Scutellospora & 2 & 3 \\
Gigaspora & 0 & 2 \\
Total de espécies & 12 & 22 \\
\hline
\end{tabular}


Tabela 6. Freqüência relativa de ocorrência de espécies de FMAs em dois sistemas de produção de plantas cítricas: convencional e orgânico

\begin{tabular}{|c|c|c|}
\hline Freqüência & \multicolumn{2}{|c|}{ Espécies de FMAs } \\
\hline $\begin{array}{c}\text { Relativa * } \\
(\%)\end{array}$ & Convencional & Orgânico \\
\hline 75 & - & Glomus macrocarpum \\
\hline 62 & Glomus microcarpum & $\begin{array}{l}\text { Glomus fasciculatum, Glomus } \\
\text { etunicatum, Entrophospora colombiana }\end{array}$ \\
\hline 50 & Glomus fasciculatum & $\begin{array}{l}\text { Glomus sp.1, Acaulospora mellea, } \\
\text { Acaulospora morrowiae, Acaulospora } \\
\text { scrobiculata }\end{array}$ \\
\hline 37 & $\begin{array}{l}\text { Glomus sp.1, Glomus } \\
\text { macrocarpum, Acaulospora } \\
\text { morrowiae }\end{array}$ & $\begin{array}{l}\text { Glomus microagregatum, Glomus } \\
\text { microcarpum, Glomus sinuosum }\end{array}$ \\
\hline 25 & $\begin{array}{l}\text { Archaeospora gerdemannii, } \\
\text { Scutellospora cerradensis }\end{array}$ & $\begin{array}{l}\text { Glomus mosseae, Scutellospora } \\
\text { heterogama, Acaulospora rehmi }\end{array}$ \\
\hline 12 & $\begin{array}{l}\text { Glomus diaphanum, Glomus } \\
\text { sp.2, Glomus etunicatum, } \\
\text { Scutellospora pellucida, } \\
\text { Acaulospora laevies }\end{array}$ & $\begin{array}{l}\text { Glomus sp.2, Glomus claroideum, } \\
\text { Acaulospora sp.1, Acaulospora laevis, } \\
\text { Scutellospora calospora, Scutellospora } \\
\text { pellucida, Gigaspora margarita, } \\
\text { Gigaspora decipiens }\end{array}$ \\
\hline
\end{tabular}

* Freqüência relativa é o número de amostras em que ocorre a espécie dividido pelo número total de amostras $(\mathrm{n}=8)$ e multiplicado por 100 
Tabela 7. Riqueza, índice de diversidade e concentração da dominância de FMAs em dois sistemas de produção de plantas cítricas: convencional e orgânico

\begin{tabular}{cccc}
\hline $\begin{array}{c}\text { Sistema de } \\
\text { produção }\end{array}$ & Riqueza $^{1}$ & $\begin{array}{c}\text { Diversidade }^{2} \\
\text { (índice de Whittaker) }\end{array}$ & $\begin{array}{c}\text { Concentração da dominância }^{3} \\
\text { (índice de Simpson) }\end{array}$ \\
\hline Convencional & $3,3 \pm 0,7$ & $2,7 \pm 0,4$ & $0,68 \pm 0,09 *$ \\
Orgânico & $7,5 \pm 0,9 *$ & $4,3 \pm 0,3 *$ & $0,35 \pm 0,07$ \\
\hline
\end{tabular}

Nas colunas, $(*)$ indica que há diferença entre médias $(\mathrm{P} \leq 0,05)$ pelo teste $\mathrm{t}$. Apresentação: média \pm erro padrão. Número de amostras por sistema $=8$

${ }^{1}$ Riqueza $=\mathrm{S}(\mathrm{S}=$ número de espécies por amostra $) ;{ }^{2}$ Diversidade $=\mathrm{S} / \log \mathrm{N}(\mathrm{N}=$ número de esporos por amostra); ${ }^{3}$ Concentração da dominância $=\sum\left(\mathrm{p}_{\mathrm{i}}\right)^{2}\left(\mathrm{p}_{\mathrm{i}}=\right.$ proporção de esporos que pertencem à espécie $i$ por amostra, sendo que i varia de $1 \mathrm{a} S$ )

\subsection{Discussão}

A biomassa microbiana é definida como a parte viva da matéria orgânica do solo e é considerado um indicador sensível de mudanças nos ecossistemas (Moreira \& Siqueira, 2002). Nesse sentido, mesmo com diferença apenas na coleta de março, o resultado de maior carbono da biomassa do solo é positivo para o manejo orgânico. Nas duas épocas de amostragem, a respiração basal foi sempre mais alta no sistema orgânico, o que refletiu em um mais alto quociente metabólico (respiração/biomassa). Se por um lado, essa alta atividade dos microrganismos sem relação proporcional com o aumento na biomassa pode ser interpretada como um indicador de ambiente estressado (Wardle, 1994), por outro, pode estar refletindo uma diferente composição da comunidade microbiana e uma maior disponibilidade de resíduos orgânicos com baixa relação $\mathrm{C} / \mathrm{N}$ (Venzke, 1999; Fortes Neto, 2000). Não se espera que existam mais fatores de estresse no manejo orgânico, que segue as normas de uma certificadora reconhecida internacionalmente, que no convencional. É mais provável que a segunda hipótese seja verdadeira. Duas explicações são propostas:

a) a aplicação periódica do biofertilizante sobre as ervas espontâneas roçadas pode estar proporcionando um resíduo com menor relação $\mathrm{C} / \mathrm{N}$ que aquele gerado no sistema convencional com a aplicação de herbicidas; b) a maior quantidade de raízes no cultivo 
orgânico deve estar resultando em maior disponibilidade de exsudatos de baixo peso molecular (açúcares, compostos aminados, ácidos orgânicos, etc) e compostos da autólise de células da epiderme e córtex, que significam importantes fontes de carbono e nitrogênio para os microrganismos do solo (Cardoso \& Freitas, 1992).

Ambos os manejos não utilizam a prática de incorporação de matéria orgânica no solo e devido a esse fato, possivelmente, não se diferenciaram em atividade de celulase na camada de solo analisada. Downer et al. (2001) também não detectaram diferença na atividade de enzimas celulolíticas nas camadas de 0 a $15 \mathrm{~cm}$ de profundidade do solo em dois sistemas de produção de abacate com e sem cobertura morta. Porém, esses autores observaram maior atividade desse complexo enzimático no interior da cobertura morta e na interface com o solo.

Futuros estudos explorando a atividade enzimática e a composição dos resíduos de ervas espontâneas roçadas nos pomares de citros podem trazer mais subsídios para o entendimento do desenvolvimento de P. parasitica. Downer et al. (2001) associaram maior atividade microbiana e atividade de celulase com o sucesso no controle biológico de Phytophthora cinnamomi em sistemas de produção de abacate e Feichtenberger (2001) relatou que a adição de matéria orgânica com baixa relação $\mathrm{C} / \mathrm{N}$ estimula a comunidade microbiana, a qual possui efeitos antagônicos a espécies de Phytophthora que parasitam as plantas cítricas.

Alta colonização radicular por FMAs nas plantas cítricas no campo ocorre freqüentemente em diferentes locais e porta-enxertos. No Brasil, pomares enxertados em limão 'Cravo' na Bahia e Sergipe e em Poncirus trifoliata no Rio Grande do Sul apresentaram colonização micorrízica de 60 a $80 \%$ e maior que $60 \%$, respectivamente (Weber \& Oliveira, 1994; Souza et al., 2002). Em outros países, amostragens em pomares de citros com vários porta-enxertos também mostraram elevada infecção radicular: 85\% em raízes amostradas em Basilicata na Italia e até 90\% na Flórida nos Estados Unidos (Schubert et al., 1993; Graham \& Eissenstat, 1998). No entanto, níveis de colonização inferiores a 50\% já foram relatados (Oliveira et al., 1986; Oliveira \& Coelho, 1995; Michel-Rosales \& Valdés, 1996). Vários fatores têm sido relacionados com o desenvolvimento dos fungos micorrízicos no interior das raízes de plantas cítricas 
em campo, como o teor de fósforo no solo (Oliveira et al., 1986; Weber \& Oliveira, 1994; Oliveira \& Coelho, 1995), a textura do solo (Oliveira et al., 1986), aplicação de agrotóxicos (Graham \& Eissenstat, 1998; Carrenho et al., 2000), época do ano (Singh et al., 1992; Michel-Rosales \& Valdés, 1996) e características genéticas das plantas e fungos em simbiose (Graham \& Eissenstat, 1994; 1998). Apesar de que os teores de fósforo detectados nos sistemas de produção convencional e orgânico (Tabela 1) se encontravam dentro da faixa considerada alta para a cultura do citros, a colonização não foi prejudicada. A época do ano não deve ter sido um fator determinante para o alto nível de colonização observada. Em outros meses do ano (janeiro, abril, maio e agosto), amostragens foram realizadas e a colonização sempre foi maior que 80 \% (dados não apresentados). Com relação à aplicação de agrotóxicos direcionados ao solo, os principais produtos utilizados no sistema convencional são os herbicidas, principalmente o glifosato. Como não houve diferença entre os dois tipos de manejo, supõe-se que esse herbicida não teve efeito sobre a porcentagem de raiz colonizada, o que concorda com os resultados de Santos (1989) e Carvalho et al. (1995). É possível que a textura arenosa do solo dos sistemas de produção (Neossolo Quartzarênico) tenha sido um aspecto favorável para a colonização radicular, como sugerido por Oliveira et al. (1986). No entanto, mais recentemente, estudos com citros têm indicado grande relevância das características genéticas tanto do hospedeiro como do fungo micorrízico sobre a taxa e o nível de colonização (Graham \& Eissenstat, 1994; 1998). Segundo esses autores, espécies de FMAs agressivas são comuns no campo e desenvolvem elevada colonização nas raízes de certas espécies de plantas cítricas até em altos níveis de fósforo. A análise da colonização radicular no campo é importante para a comprovação do desenvolvimento da simbiose, porém a interpretação do significado dos diferentes níveis é difícil. Altos níveis de colonização podem gerar efeito depressivo no crescimento dos citros (Graham \& Eissenstat, 1994; 1998). No entanto, esse tipo de interação, que à primeira vista pode parecer negativo para a cultura, pode proporcionar outras vantagens competitivas para as plantas, como a redução dos efeitos deletérios dos patógenos de raiz (Graham, 2001). 
Das espécies identificadas nos sistemas de produção orgânico e convencional, 15 já tinham sido relatadas em levantamentos anteriores em pomares de citros no Brasil (Caldeira et al., 1983; Siqueira et al., 1989; Weber \& Oliveira, 1994; Rego, 2000; Souza et al., 2002) e, ou, nos Estados Unidos (Nemec et al., 1981; Davis, 1982): G. macrocarpum, G. etunicatum e G. margarita em ambos os países; G. claroideum, A. morrowiae, A. scrobiculata, A. rehmi, A.mellea, S. heterogama e E. colombiana no Brasil; e G. fasciculatum, G. microcarpum, G. mosseae, G. sinuosum e S. heterogama nos Estados Unidos. Os levantamentos brasileiros citados anteriormente foram realizados em regiões citrícolas da Bahia e Sergipe, do Rio Grande do Sul e de Minas Gerais, porém, na literatura revisada não foi encontrado nenhum estudo dessa natureza no Estado de São Paulo.

Foi observada predominância das espécies no gênero Glomus (Tabela 5), concordando com a maioria dos outros estudos realizados em citros (Nemec et al., 1981; Oliveira et al., 1986; Singh et al., 1992; Rego, 2000; Souza et al., 2002). As exceções foram Siqueira et al. (1989) e Weber \& Oliveira (1994), que relataram predominância no gênero Acaulospora. Esses autores relacionaram seus resultados com níveis de acidez no solo dos pomares $(\mathrm{pH}<6,5)$. Porém, essa hipótese não tem sido confirmada. Os solos dos cultivos nos quais prevaleceu o gênero Glomus, inclusive no presente estudo (Tabela 1), não apresentaram níveis mais elevados de $\mathrm{pH}$.

O número de espécies de FMAs obtido no sistema convencional concordou com a média mencionada por Siqueira et al. (1989) para agroecossistemas. No entanto, o alto número de espécies no sistema orgânico foi comparável ao esperado em ecossistemas não cultivados (Siqueira et al., 1989; Moreira-Souza et al., 2003). Considerando que os dois sistemas de produção estão sob as mesmas condições de clima e tipo de solo, propõe-se que os diferentes manejos estão proporcionando diferentes comunidades de fungos micorrízicos. Rego (2000) aplicou várias práticas culturais de manejo de ervas espontâneas e identificou nas parcelas tratadas com glifosato nas linhas e roçagem nas entrelinhas apenas duas espécies de FMAs, enquanto nas parcelas com roçagem em área total, oito espécies. No sistema convencional se utiliza o manejo com herbicida glifosato nas linhas e roçagem nas entrelinhas e no orgânico, roçagem em toda área. Essas e 
outras práticas culturais provavelmente influenciam a riqueza e a diversidade da comunidade de FMAs. O índice de diversidade (Whittaker) calculado para o sistema orgânico (Tabela 7) foi similar aos obtidos nos estudos de rizosfera de Araucaria em floresta nativa em Campos do Jordão, São Paulo (Moreira-Souza, 2003) e de plantações de cacau sombreado na Venezuela (Cuenca \& Meneses, 1996). Do ponto de vista ecológico, Abbott \& Gazey (1994) sugerem que deve ser uma vantagem para o sistema manter altos níveis de diversidade de FMAs no solo, independente da contribuição individual de cada espécie, pois isto poderia garantir uma máxima chance de que as espécies mais adaptadas dominassem quando as condições de solo fossem modificadas.

Embora a ordem da freqüência relativa de ocorrência das espécies de fungos micorrízicos tenha sido distinta em cada sistema de produção (Tabela 6), em termos de abundância (número total de esporos), a espécie G. fasciculatum dominou em ambos os sistemas. G. fasciculatum foi consistentemente associada com árvores jovens de citros (menos de 30 anos) no estudo de Nemec et al. (1981). O grande número de esporos produzidos por esse fungo e o menor número de espécies por amostra resultou numa maior concentração da dominância no sistema convencional (Tabela 7).

Finalmente, a menor quantidade de raízes de plantas cítricas no sistema convencional levanta muitas inquietudes. Quais seriam as práticas de manejo que estariam prejudicando ou não estimulando o desenvolvimento das raízes sob a copa nos primeiros $20 \mathrm{~cm}$ de profundidade nesse sistema? O tipo e o local de adubação? A aplicação de herbicidas? Outros estudos são necessários para explicar esses resultados.

\subsection{Conclusões}

O manejo orgânico está promovendo maior atividade microbiana do solo e maior diversidade de fungos micorrízicos arbusculares que o manejo convencional.

A colonização micorrízica foi elevada nas plantas de ambos os manejos. 


\section{QUAL TESTEMUNHA NÃO MICORRIZADA UTILIZAR EM ESTUDOS DE INTERAÇÃO DE Phytophthora parasitica E FUNGOS MICORRÍZICOS ARBUSCULARES NATIVOS EM CITROS?}

\section{Resumo}

A seleção do método de desinfestação de solo para obtenção de testemunha não micorrizada em trabalhos de interação de comunidade de fungos micorrízicos arbusculares (FMAs) nativos e patógenos de raiz deve ser realizada de forma criteriosa. Em casa de vegetação, três experimentos foram realizados para avaliação da aplicação do fungicida benomyl e da radiação $\gamma$ na obtenção de testemunhas não micorrizadas de plantas cítricas para estudo de interação $P$. parasitica- FMAs nativos de agroecossistemas convencional e orgânico de produção de laranja. Nos experimentos 2 e 3 foram usados vasos de menor volume com o fim de se estudar também a possibilidade de se trabalhar com volume reduzido de solo. Nos experimentos 1 e 2, a aplicação de benomyl nos solos naturais dos sistemas convencional e orgânico provocou resposta positiva no crescimento das plantas de limão 'Cravo' e diminuição dos teores de fósforo na parte aérea, porém nem sempre diminuiu a colonização micorrízica. $\mathrm{O}$ experimento 3 mostrou que a comunidade FMAs nativa de ambos os sistemas de produção contribuiu para a absorção de fósforo, magnésio, manganês, zinco e cobre. A severidade de podridão de raízes, no experimento 1 , foi maior nas plantas cultivadas no solo do sistema convencional que receberam benomyl. Muitas interações do benomyl com os solos dos sistemas de produção ocorreram. Portanto, a radiação $\gamma$ foi mais adequada que a aplicação do fungicida benomyl na obtenção de uma testemunha satisfatória para experimento de controle biológico de $P$. parasitica por FMAs nativos de pomares de 
plantas cítricas com diferentes tipos de manejo. A utilização de volumes reduzidos de solo não foi adequada para a realização desse tipo de experimento.

\section{WHICH NON-MYCORRHIZAL CONTROL SHOULD BE USED IN STUDIES OF INTERACTION BETWEEN Phytophthora parasitica AND INDIGENOUS ARBUSCULAR MYCORRHIZAL FUNGI IN CITRUS?}

\section{Summary}

The selection of a partial sterilization method of soil to obtain a non-mycorrhizal control in studies of interaction between indigenous arbuscular mycorrhizal fungi (AMF) communities and root pathogens must be done in a critical way. In greenhouse, three experiments were carried out to evaluate benomyl and $\gamma$ radiation to create nonmycorrhizal controls in studies of interaction between $P$. parasitica and indigenous AMF from conventional and organic citrus agroecosystems. In experiments 2 and 3, we used smaller pots to study the possibility to work with a reduced soil volume. In experiments 1 and 2, the use of benomyl in natural soils of conventional and organic agroecosystems resulted in a positive plant growth response and a reduced phosphorus level in shoot. However, mycorrhizal root colonization was not always affected. Experiment 3 showed that the indigenous AMF communities of both agroecosystems contributed to phosphorus, magnesium, manganese, zinc and cupper absorption. In experiment 1, plants cultivated on the conventional farming soil that received benomyl had the highest root rot severity. There were several interactions between benomyl and the agroecosystems soils. Therefore, $\gamma$ radiation was better than benomyl to obtain a non-mycorrhizal control. The use of reduced volume of soil was not satisfactory for this type of experiment. 


\subsection{Introdução}

Todos os métodos empregados para a desinfestação de solo, com o fim de obter testemunhas para estudos dos fungos micorrízicos arbusculares (FMAs), têm vantagens e desvantagens. Em experimentos em casa de vegetação com FMAs, a fumigação com brometo de metila, a autoclavagem e a irradiação com raios $\gamma$ têm sido métodos utilizados. O uso do brometo de metila deve ser desestimulado, pois esse produto atualmente se encontra em processo de proibição devido a seus efeitos negativos para o ambiente e o homem (Ghini, 2001). Entre os outros dois métodos, a irradiação $(\gamma)$, quando disponível, aplicada em doses baixas $(<10 \mathrm{KGy})$, vem sendo preferida pelas poucas mudanças provocados sobre as condições nutricionais do solo (Kahiluoto et al., 2000). Quando se pretende estudar a resposta da comunidade de FMAs nativos de um determinado solo sobre um cultivo diretamente em campo ou em casa de vegetação, simulando condições de campo, o fungicida benomyl tem sido recomendado (Graham \& Eissenstat, 1998; Kahiluoto et al., 2000). Benomyl e outros fungicidas do grupo ao qual pertence (grupo dos Benzimidazóis) são conhecidos por seus efeitos deletérios sobre a simbiose micorrízica, principalmente quando aplicados ao solo (Trappe et al., 1984; Perrin \& Plenchette, 1993).

Como o benomyl não é prejudicial a Phytophthora parasitica (Tsao, 1983), esse poderia ser utilizado também em experimentos de controle biológico desse patógeno por FMAs nativos. Bødker et al. (2002) produziram testemunha não micorrizada em campo com o fungicida carbendazim (Benzimidazol) para seus estudos de interação de FMAs e o patógeno Aphanomyces euteiches (Oomyceto) em ervilha. Na literatura, não foram encontrados relatos sobre a utilização de benomyl nesses tipos de experimentos com $P$. parasitica. Considerando que interações entre benomyl e os diferentes componentes bióticos e abióticos do solo podem ocorrer, avaliações específicas devem ser realizadas. Portanto, o objetivo do presente estudo foi avaliar a aplicação de benomyl e da radiação $\gamma$ como formadores de testemunhas para estudo de interação P. parasitica- FMAs nativos em plantas cítricas. Foram realizados três experimentos. Com base nos resultados obtidos no experimento 1 , foram planejados os experimentos 2 e 3 , utilizando vasos de menor capacidade que os do experimento 1, com a finalidade de se estudar 
também a possibilidade de se trabalhar com volume reduzido de solo, já que a coleta de grande quantidade de solo no campo é muito laboriosa.

\subsection{Material e Métodos}

Os solos utilizados nos três experimentos foram coletados em diferentes épocas (Quadro 1), porém sempre nos mesmos lotes de duas propriedades produtoras de plantas cítricas vizinhas, na região da divisa Piracicaba-Botucatu, SP (aproximadamente aos 45 Km de Piracicaba na via para Anhembi). Os lotes possuem árvores de laranja 'Pêra' (Citrus sinensis) enxertada em limão 'Cravo' (Citrus limonia), com 10 a 12 anos de idade, plantadas em solo do tipo Neossolo Quartzarênico, no entanto, são manejados de formas distintas, um seguindo o sistema de manejo convencional e o outro o sistema orgânico. Em cada coleta, foram retiradas amostras de solo de 15 árvores (quatro pontos/árvore), de 0 a $20 \mathrm{~cm}$ de profundidade e distantes cerca de $60 \mathrm{~cm}$ do tronco. Posteriormente, as amostras de cada sistema foram misturadas para serem utilizadas nos experimentos de casa de vegetação. Metade do solo de cada coleta foi mantida na sua forma natural (com a comunidade de FMAs nativos) e a outra metade foi tratada com radiação $\gamma(6 \mathrm{KGy})$. Análises de fertilidade dos solos foram realizadas no Laboratório de Análise de Solo e Planta do Instituto Agronômico (IAC), Campinas (Tabela 1). O solo coletado foi armazenado em lugar fresco a temperatura ambiente.

Sementes de limão 'Cravo', previamente tratadas com hipoclorito de sódio a 2,5\% por $10 \mathrm{~min}$, foram utilizadas. No experimento 1, as sementes foram germinadas em areia autoclavada e plântulas de um mês de idade foram transplantadas para vasos de alumínio com 1,5 L de solo. Nos experimentos 2 e 3, foi realizada semeadura direta em vasos plásticos, contendo $300 \mathrm{~mL}$ de solo. Para introduzir a microbiota nativa do solo, sem os FMAs, uma suspensão de solo natural em água (1:6) foi filtrada na peneira de $45 \mu \mathrm{m}$ e aplicada aos vasos com solo irradiado (100mL/vaso no experimento 1 e $60 \mathrm{~mL}$ nos experimentos 2 e 3). Para cada experimento, foram obtidos filtrados com os solos naturais convencional e orgânico. Como recomendado por Graham \& Eissenstat (1998), o fungicida benomyl (Benlate ${ }^{\circledR}$ 500) foi aplicado, até drenar, no solo dos vasos 
correspondentes a esse tratamento, na dose de $0,6 \mathrm{~g}$ i.a. $\mathrm{L}^{-1}$, aproximadamente a cada 45 dias (Quadro 1).

\begin{tabular}{|c|c|c|c|}
\hline Atividade & Experimento 1 & Experimento 2 & Experimento 3 \\
\hline Coleta do solo em campo & $4 / 4 / 2001$ & $20 / 8 / 2001$ & $9 / 3 / 2002$ \\
\hline Período do experimento & $14 / 3$ a $12 / 12 / 2001$ & $13 / 3$ a $4 / 8 / 2002$ & $8 / 5$ a $9 / 12 / 2002$ \\
\hline Aplicação de benomyl & $23 / 4,6 / 6,1 / 8$, & $6 / 5,28 / 6 / 2002$ & $18 / 9,4 / 11 / 2002$ \\
& $15 / 9,16 / 11 / 2001$ & & \\
\hline Infestação com & $5 / 11 / 2001$ & $12 / 6 / 2002$ & $21 / 10 / 2002$ \\
P. parasitica & & & \\
\hline
\end{tabular}

Quadro 1 - Data das atividades realizadas nos três experimentos de interação de FMAs nativos e $P$. parasitica em plantas de limão 'Cravo', realizados em casa de vegetação no Centro Experimental Central, IAC, Campinas, SP

O isolado de P. parasitica foi cedido pela Clínica Fitopatológica do Centro APTA Citros Sylvio Moreira, Cordeirópolis, SP. O patógeno foi preservado por repicagens em meio de cultura e pelo método de Castellani, a temperatura ambiente. Para o crescimento e produção de esporângios, foi utilizado o meio de cenoura: $50 \mathrm{~g}$ de cenoura, $10 \mathrm{~g}$ de dextrose, $20 \mathrm{~g}$ de agar, para $1 \mathrm{~L}$ de meio (May \& Kimati, 1997). A infestação com P. parasitica foi realizada segundo o método descrito em Araújo (1998), com algumas modificações. Das bordas de colônias de 1 semana de idade crescidas no escuro, a temperaturas de 28 a $30{ }^{\circ} \mathrm{C}$, foram retirados discos de $7 \mathrm{~mm}$ de diâmetro e transferidos para placas de Petri (Pyrex). Essas placas receberam $25 \mathrm{~mL}$ de água destilada esterilizada e discos de folhas de limão 'Cravo' de 7 mm de diâmetro, e foram mantidas por sete dias em luz fluorescente contínua, a temperatura ambiente. Esse procedimento foi realizado com o fim de estimular a produção de esporângios nos discos de micélio e folhas para serem utilizados na infestação dos vasos. Nos três experimentos, foram batidas no liquidificador, com água destilada esterilizada, colônias de 15 dias de idade, cultivadas nas mesmas condições já descritas. Essa suspensão de hifas foi 
aplicada no solo dos vasos. No experimento 1, $80 \mathrm{~mL}$ da suspensão de seis placas, com meio inclusive, batidas com 66 discos de micélio com esporângios para 1 L de suspensão, foram aplicados em cada vaso. No experimento 2, cada vaso recebeu $30 \mathrm{~mL}$ da suspensão de hifas superficiais de 12 placas $\mathrm{L}^{-1}$, além de cinco discos de folhas e um de micélio enterrados ao redor da planta. No experimento 3, foram misturadas duas placas inteiras (inclusive meio), micélio superficial de seis placas e discos de micélio (45) e de folhas (45) para $1 \mathrm{~L}$ de suspensão, que foi aplicada na quantidade de $30 \mathrm{~mL}$ por vaso.

Apenas o terceiro experimento recebeu fertilização. Foi preparada uma solução estoque de $\mathrm{KNO}_{3} 1 \mathrm{M}$. A partir de três meses após instalado o experimento, duas vezes por semana, foram aplicados $50 \mathrm{~mL}$ por vaso da solução diluída (3mL da solução estoque $\left.\mathrm{L}^{-1}\right)$. Três meses depois, a concentração da solução foi aumentada $(10 \mathrm{~mL}$ da solução estoque $\mathrm{L}^{-1}$ ).

No experimento 1, o desenho experimental foi inteiramente casualisado com arranjo fatorial $2 \times 4 \times 2$, com 10 repetições por tratamento. Os fatores principais e seus respectivos níveis foram os seguintes: sistema de produção (convencional e orgânico); tratamento de solo (natural, benomyl, radiação $\gamma$ com e sem filtrado de solo); infestação de P.parasitica (sem e com infestação artificial). Nos experimentos 2 e 3, o desenho foi inteiramente casualisado com arranjo fatorial $2^{4}$ : sistemas de produção convencional e orgânico; solos natural e após irradiação $\gamma$ (com filtrado); aplicação ou não de benomyl; infestação artificial ou não de P.parasitica. Houve 5 repetições para os tratamentos com solo irradiado e 10 repetições para os com solo natural no experimento 2, e 5 repetições para os tratamentos com benomyl e 7 para os sem benomyl no experimento 3. Os três experimentos foram realizados em casa de vegetação, no Centro Experimental Central, do Instituto Agronômico (IAC), Campinas, SP, nos anos de 2001 e 2002 (Quadro 1). As temperaturas médias mínimas e máximas diárias a partir de junho de 2001 e até o final dos experimentos estão apresentadas na Figura 1. 
Tabela 1. Análise de fertilidade dos solo dos sistemas de produção de plantas cítricas, orgânico e convencional, em sua condição natural e após irradiação $(\gamma)$, utilizados nos experimentos 1,2 e 3

\begin{tabular}{|c|c|c|c|c|c|c|c|c|c|c|c|c|c|c|}
\hline \multicolumn{3}{|c|}{ Determinações } & \multicolumn{12}{|c|}{ Sistemas de produção } \\
\hline \multirow[t]{3}{*}{ Sigla } & \multirow[t]{3}{*}{ Descrição } & \multirow[t]{3}{*}{ Unidade } & \multicolumn{6}{|c|}{ Orgânico } & \multicolumn{6}{|c|}{ Convencional } \\
\hline & & & \multicolumn{3}{|c|}{$\begin{array}{c}\text { Natural } \\
\text { Experimento }\end{array}$} & \multicolumn{3}{|c|}{$\begin{array}{c}\text { Irradiado } \\
\text { Experimento }\end{array}$} & \multicolumn{3}{|c|}{$\begin{array}{c}\text { Natural } \\
\text { Experimento }\end{array}$} & \multicolumn{3}{|c|}{$\begin{array}{l}\text { Irradiado } \\
\text { Experimento }\end{array}$} \\
\hline & & & 1 & 2 & 3 & 1 & 2 & 3 & 1 & 2 & 3 & 1 & 2 & 3 \\
\hline M.O. & Mat. org. & $\mathrm{g} \mathrm{m}^{-3}$ & 17 & 16 & 15 & 15 & 16 & 18 & 16 & 20 & 12 & 13 & 17 & 16 \\
\hline pH & Sol $\mathrm{CaCl}_{2}$ & & 6,6 & 6,6 & 6,3 & 6,7 & 6,3 & 6,8 & 5,7 & 6,2 & 5,5 & 5,8 & 6,3 & 5,6 \\
\hline $\mathbf{P}$ & Resina & $\mathrm{mg} \mathrm{dm}^{-3}$ & 35 & 30 & 50 & 32 & 42 & 48 & 40 & 75 & 43 & 26 & 88 & 44 \\
\hline $\mathbf{K}$ & Potássio & $\mathrm{mmol}_{\mathrm{c}} \mathrm{dm}^{-3}$ & 0,4 & 0,6 & 0,3 & 0,6 & 0,8 & 0,6 & 0,6 & 3,0 & 1,0 & 0,8 & 3,0 & 0,9 \\
\hline Ca & Cálcio & $\mathrm{mmol}_{\mathrm{c}} \mathrm{dm}^{-3}$ & 47 & 59 & 59 & 52 & 64 & 61 & 26 & 48 & 26 & 27 & 61 & 40 \\
\hline Mg & Magnésio & $\mathrm{mmol}_{\mathrm{c}} \mathrm{dm}^{-3}$ & 27 & 19 & 23 & 27 & 34 & 32 & 12 & 24 & 12 & 14 & 37 & 24 \\
\hline $\mathbf{H}+\mathbf{A l}$ & Ac. Pot. & $\mathrm{mmol}_{\mathrm{c}} \mathrm{dm}^{-3}$ & 9 & 9 & 8 & 9 & 10 & 8 & 16 & 11 & 16 & 13 & 12 & 15 \\
\hline S.B. & Soma bases & $\mathrm{mmol}_{\mathrm{c}} \mathrm{dm}^{-3}$ & 74,4 & 78,6 & 82,3 & 79,6 & 98,8 & 93,6 & 38,6 & 75 & 39 & 41,8 & 101,0 & 64,9 \\
\hline СТC & Cap.Tr. Cat. & $\mathrm{mmol}_{\mathrm{c}} \mathrm{dm}^{-3}$ & 83,1 & 87,3 & 90,1 & 88,3 & 108,5 & 101,4 & 55 & 85,8 & 55,4 & 55,1 & 113,0 & 79,7 \\
\hline $\mathbf{V}$ & Sat. Bases & $\%$ & 90 & 90 & 91 & 90 & 91 & 92 & 70 & 87 & 70 & 76 & 89 & 81 \\
\hline B & Boro & $\mathrm{mg} \mathrm{dm}$ & 0,19 & 0,19 & 0,12 & 0,17 & 0,24 & 0,18 & 0,26 & 0,25 & 0,14 & 0,17 & 0,29 & 0,19 \\
\hline $\mathbf{C u}$ & Cobre & $\mathrm{mg} \mathrm{dm}{ }^{-3}$ & 1,8 & 3,0 & 2,9 & 2,9 & 3,3 & 3,8 & 1,5 & 14,3 & 6,3 & 5,8 & 14,1 & 9,3 \\
\hline $\mathbf{F e}$ & Ferro & $\mathrm{mg} \mathrm{dm}$ & 17 & 8 & 12 & 9 & 9 & 22 & 17 & 23 & 41 & 33 & 19 & 62 \\
\hline Mn & Manganês & $\mathrm{mg} \mathrm{dm}{ }^{-3}$ & 11,5 & 11,6 & 10,0 & 6,5 & 11,2 & 15,6 & 34,2 & 8,5 & 4,4 & 3 & 6,7 & 6,0 \\
\hline Zn & Zinco & $\mathrm{mg} \mathrm{dm}{ }^{-3}$ & 5,7 & 7,0 & 7,3 & 7,1 & 8,2 & 8,7 & 5,1 & 8,3 & 2,2 & 2,1 & 7,8 & 3,0 \\
\hline
\end{tabular}

Métodos de extração: P - resina; B - água quente; $\mathrm{Cu}, \mathrm{Fe}, \mathrm{Mn}, \mathrm{Zn}$ - DTPA 


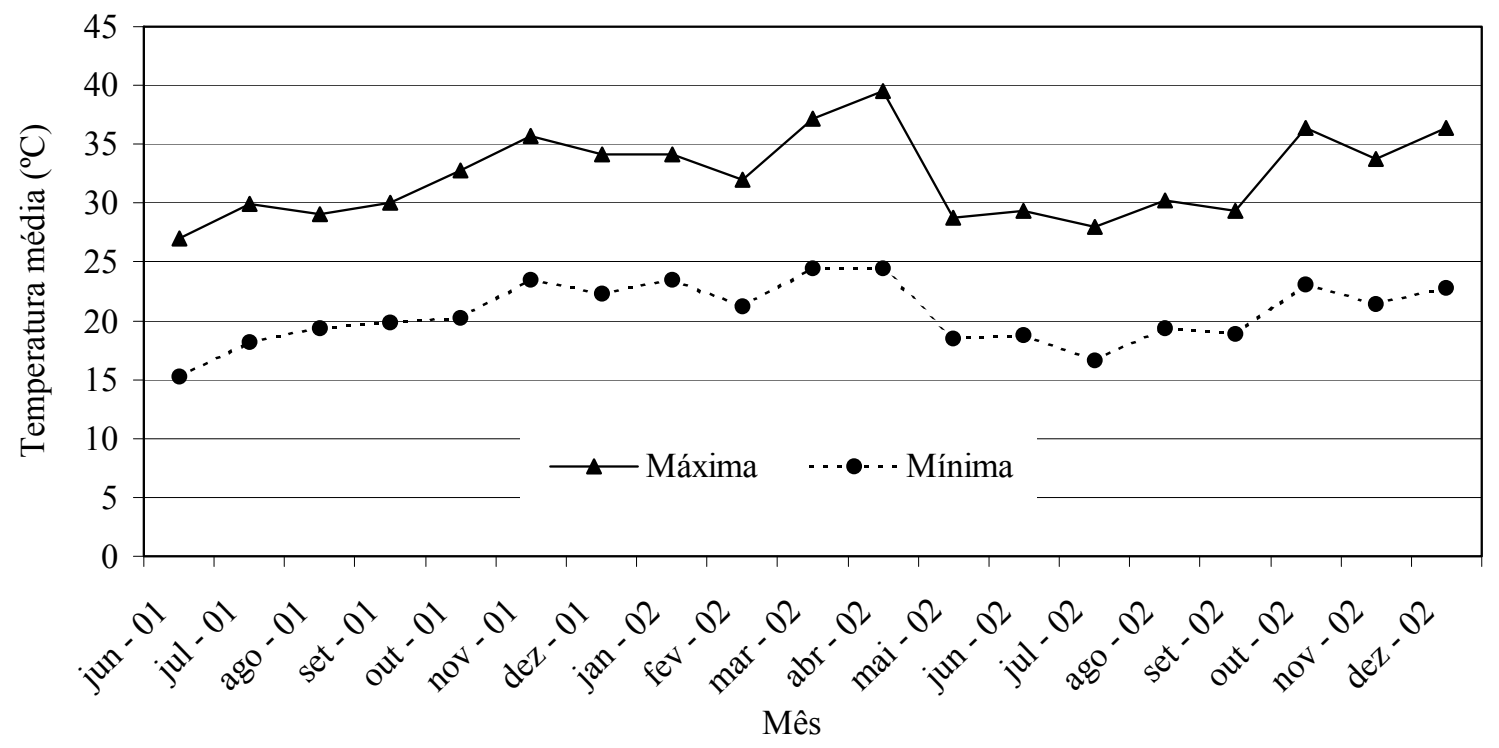

Figura 1 - Médias das temperaturas mínimas e máximas diárias de junho de 2001 a dezembro de 2002 na casa de vegetação (Centro Experimental Central -IAC, Campinas, SP)

A altura das plantas foi avaliada durante a realização dos experimentos e as demais variáveis, descritas a seguir, somente no final:

- massa da matéria fresca de raiz;

- massas da matéria seca de parte aérea (MSA) e de raiz (MSR): plantas secas em estufa a $60{ }^{\circ} \mathrm{C}$ por 5 dias. A resposta micorrízica foi obtida pela seguinte fórmula: (MSA+MSR de planta micorrizada/ MSA+MSR de planta não micorrizada) -1 (Graham \& Abbott, 2000);

- severidade de podridão de raízes: escala visual de notas de 0 a 5 , sendo $0=$ raízes sem nenhum sintoma e 5=raízes completamente necrosadas (Pozo et al., 2002);

- colonização radicular por FMAs nativos: as raízes foram guardadas em álcool 50\%. Posteriormente, foram lavadas em água corrente, clarificadas com $\mathrm{KOH} \mathrm{10 \%} \mathrm{em} \mathrm{banho-}$ 
maria fervendo por 15 min, novamente lavadas, e colocadas em uma solução a 5\% de tinta de caneta (Parker, preta) e vinagre branco de cozinha puro (4\% de ácido acético) por 3-4 min em banho maria fervendo (Vierheilig et al., 1998). Depois de lavados em água corrente, 30 segmentos de $1 \mathrm{~cm}$ de raiz colorida por planta foram montados em lâminas e observados em microscópio para a determinação da porcentagem de colonização micorrízica (Giovannetti \& Mosse, 1980);

- teor de fósforo de parte aérea: determinado por colorimetria, pelo método de molibidato-vanadato (experimentos 1 e 2) (Bataglia et al., 1983);

- teor de nitrogênio de parte aérea: método de Kjedahl (experimentos 1 e 2) (Bataglia et al., 1983);

- teores de macro e micronutrientes na parte aérea do experimento 3 foram analisados pelo Laboratório de Análise de Solo e Planta do Instituto Agronômico (IAC), Campinas.

No final do experimento 3, quando foram desmontados os vasos de três repetições, o solo que estava ao redor das raízes de cada planta foi coletado e levado para o laboratório com a finalidade de se verificar a presença de $P$. parasitica. Foi seguido o método de isca (Grim \& Alexander, 1973), nas proporções utilizadas por Velazco (2002). Em placas de Petri (Pyrex) foram colocados $5 \mathrm{~g}$ de solo de cada vaso, $30 \mathrm{ml}$ de água destilada e 20 pedaços de folhas de limão 'Cravo' de 3x3 mm. As placas foram mantidas em luz fluorescente por sete dias, a temperaturas médias mínimas e máximas de $26{ }^{\circ} \mathrm{C}$ e $32{ }^{\circ} \mathrm{C}$, respectivamente. Foram observados ao microscópio $(125 \mathrm{x})$ 12 pedaços de folhas de cada placa (uma placa para cada vaso). Os resultados foram expressos em porcentagem de pedaços de folhas observados com presença de esporângio de Phytophthora.

Para análise estatística foi utilizado o programa SAS. Depois de realizada a análise de variância de cada variável para os três fatores e interações (procedimento Modelos Lineares Generalizados- GLM), o teste $\mathrm{t}$ foi aplicado para as comparações entre duas médias e o teste de Student-Newman-Keuls para as comparações entre várias médias. Dados de colonização e severidade foram transformados para arcoseno $\sqrt{x}_{\mathrm{x}} / 100 \mathrm{e}$ $\sqrt{x}+0,5$, respectivamente, para serem analisados. 


\subsection{Resultados}

\section{Experimento 1.}

Foi altamente significativo o efeito do fator tratamento de solo sobre todas as variáveis analisadas, enquanto que a infestação com o patógeno não teve efeito e o sistema de produção somente influenciou a severidade da doença (Tabela 2). A porcentagem de colonização radicular não diminuiu com a aplicação de benomyl, mas as plantas apresentaram menor teor de fósforo foliar que as do solo natural e maior que as dos irradiados (Tabela 3). No entanto, as plantas que receberam benomyl tiveram um melhor crescimento, refletido em valores maiores de altura, massa da matéria seca de parte aérea e massa de matéria fresca de raiz (Tabela 3). $O$ teor foliar de nitrogênio das plantas nos tratamentos com aplicação de benomyl e radiação $\gamma$ foi maior que em solo natural (Tabela 3). A aplicação de radiação $\gamma$ eliminou os FMAs nativos, o que levou à diminuição do teor de fósforo foliar (Tabela 3), porém o crescimento das plantas nos vasos que receberam filtrado não diferiram estatisticamente do observado no solo natural.

Tabela 2. Teste F da análise de variância na altura (ALT), massa da matéria seca de parte aérea (MSA), massa da matéria fresca de raiz (MFR), teor foliar de fósforo $(\mathrm{P})$ e nitrogênio $(\mathrm{N})$, colonização por FMAs nativos (COL) e severidade da podridão de raízes (SEV) em plantas de limão 'Cravo' de nove meses de idade. Os efeitos principais foram: sistemas de produção (convencional e orgânico), tratamentos de solo (natural, benomyl, radiação $\gamma$ com e sem filtrado) e $P$. parasitica. (sem e com infestação artificial)

\begin{tabular}{lccccccc}
\hline Fonte & ALT & MAS & MFR & P & N & COL & SEV \\
\hline Sistema de produção (SP) & $\mathrm{ns}$ & $\mathrm{ns}$ & $\mathrm{ns}$ & $\mathrm{ns}$ & $\mathrm{ns}$ & $\mathrm{ns}$ & $* * *$ \\
Tratamento de solo (TS) & $* * *$ & $* * *$ & $* * *$ & $* * *$ & $* * *$ & $* * *$ & $* * *$ \\
$P$. parasitica (Phy) & $\mathrm{ns}$ & $\mathrm{ns}$ & $\mathrm{ns}$ & $\mathrm{ns}$ & $\mathrm{ns}$ & $\mathrm{ns}$ & $\mathrm{ns}$ \\
SP x TS & $\mathrm{ns}$ & $\mathrm{ns}$ & $\mathrm{ns}$ & $*$ & $\mathrm{~ns}$ & $\mathrm{~ns}$ & $* *$ \\
\hline
\end{tabular}

Níveis de significância, * $(\mathrm{P} \leq 0,05), * *(\mathrm{P} \leq 0,01), * * *(\mathrm{P} \leq 0,001)$ e não significativo $(\mathrm{ns})$. Interações não apresentadas não foram significativas ou não aplicáveis 
Tabela 3. Altura (ALT), massa da matéria seca de parte aérea (MSA), massa da matéria fresca de raiz (MFR), teor foliar de fósforo $(\mathrm{P})$ e nitrogênio $(\mathrm{N})$, colonização por FMAs nativos (COL) e severidade da podridão de raízes (SEV) em plantas de limão 'Cravo' de nove meses de idade, sob quatro tratamentos de solo (natural, benomyl, radiação $\gamma$ com e sem filtrado de solo)

\begin{tabular}{|c|c|c|c|c|c|c|c|}
\hline $\begin{array}{l}\text { Tratamento } \\
\text { de solo }\end{array}$ & $\begin{array}{l}\text { ALT } \\
(\mathrm{cm})\end{array}$ & $\begin{array}{c}\text { MSA } \\
(\mathrm{g})\end{array}$ & $\begin{array}{c}\text { MFR } \\
(\mathrm{g})\end{array}$ & $\begin{array}{c}\mathrm{P} \\
\left(\mathrm{g} \mathrm{Kg}^{-1}\right)\end{array}$ & $\begin{array}{c}\mathrm{N} \\
\left(\mathrm{g} \mathrm{Kg}^{-1}\right)\end{array}$ & $\begin{array}{c}\mathrm{COL}^{1} \\
(\%)\end{array}$ & $\mathrm{SEV}^{2}$ \\
\hline \multirow[t]{2}{*}{ Natural } & $20,0 \pm 1,1(40)$ & $1,4 \pm 0,1(40)$ & $3,9 \pm 0,2(40)$ & $2,3 \pm 0,1(40)$ & $24,8 \pm 0,5(18)$ & $78,6 \pm 2,3(40)$ & $0,6 \pm 0,1(40)$ \\
\hline & $\mathrm{b}$ & $b$ & $\mathrm{~b}$ & $\mathrm{a}$ & $b$ & $\mathrm{a}$ & $b$ \\
\hline Benomyl & $29,8 \pm 2,1(40)$ & $2,5 \pm 0,2(40)$ & $5,7 \pm 0,4(40)$ & $1,9 \pm 0,1(40)$ & $29,0 \pm 0,8(19)$ & $77,6 \pm 2,0(40)$ & $1,2 \pm 0,1(40)$ \\
\hline Radiação $\gamma$ & $19,4 \pm 0,9(40)$ & $1,3 \pm 0,1(40)$ & $3,4 \pm 0,2(40)$ & $1,5 \pm 0,1(40)$ & $31,1 \pm 1,0(20)$ & $1,6 \pm 0,1(40)$ & $0,3 \pm 0,1(40)$ \\
\hline com filtrado & $\mathrm{b}$ & bc & $\mathrm{b}$ & $\mathrm{c}$ & a & $b$ & $\mathrm{~b}$ \\
\hline Radiação $\gamma$ & $15,4 \pm 1,1(16)$ & $0,8 \pm 0,1(16)$ & $2,1 \pm 0,3(16)$ & $1,4 \pm 0,1(16)$ & $30,1 \pm 1,7(8)$ & $0,4 \pm 0,1(16)$ & $0,3 \pm 0,1(16)$ \\
\hline sem filtrado & $\mathrm{b}$ & $\mathrm{c}$ & $\mathrm{c}$ & $\mathrm{c}$ & $\mathrm{a}$ & $\mathrm{b}$ & $\mathrm{b}$ \\
\hline
\end{tabular}

Nas colunas, médias seguidas das mesmas letras não diferem $(\mathrm{P} \leq 0,05)$ pelo teste de Student-Newman-Keuls

1 dados transformados para arcoseno $\sqrt{ } \mathrm{x} / 100$

${ }^{2}$ dados transformados para $\sqrt{x}+0,5$. Utilizou-se uma escala de notas $(0$ a 5$)$ para avaliação visual da severidade da doença 
No sistema convencional, o fungicida reduziu significativamente a concentração de fósforo foliar comparado ao solo natural (Figura 2), ocorrendo, entretanto, 2,5 vezes maior eficiência na conversão de $\mathrm{P}$ em matéria seca de parte aérea que no solo natural (Tabela 3). No sistema orgânico, apesar do benomyl não ter afetado o P foliar, esse produto proporcionou também uma maior eficiência de conversão, 2,2 vezes maior que no solo natural correspondente.

Várias plantas morreram depois do transplante para o solo natural (sem e com benomyl) e foram substituídas. Foram observados sintomas de podridão de raízes nas plantas mortas e foi confirmada a presença de Phytophthora nas raízes pelo método de iscas com folhas de limão 'Cravo'. Apesar de ter morrido maior número de plantas no solo do sistema orgânico, a severidade da podridão de raiz no final do experimento foi significativamente maior no sistema convencional com aplicação de benomyl (Figura 2). Somente no tratamento com benomyl, a infestação de $P$. parasitica afetou o crescimento das plantas, diminuindo em $26 \%$ a massa da matéria seca de parte aérea e $30 \%$ a massa da matéria fresca de raiz.
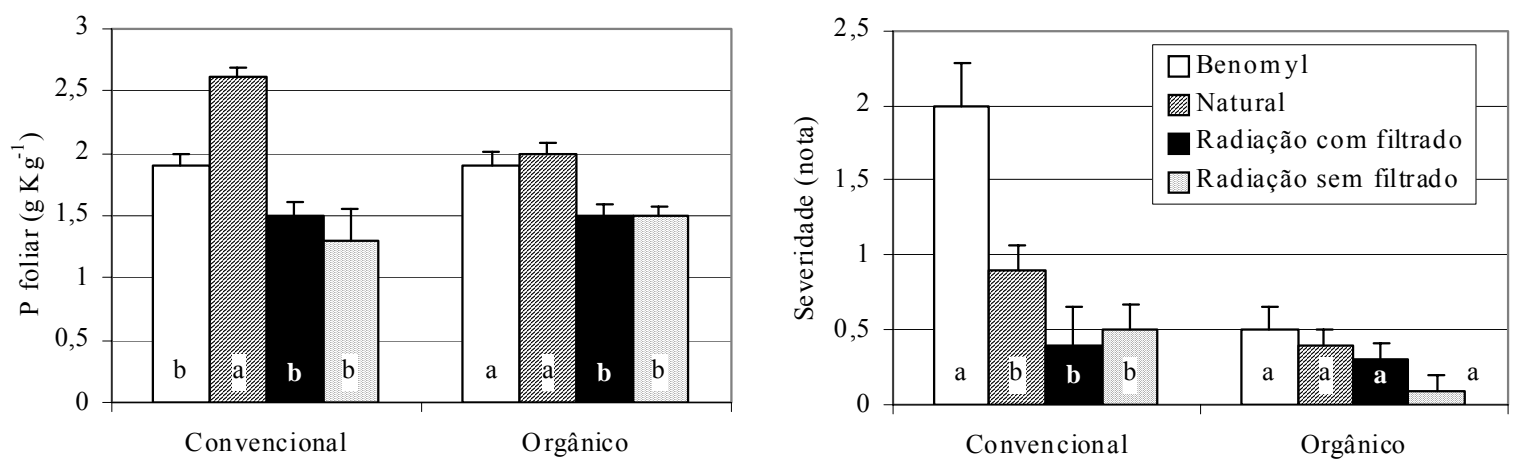

Figura 2 - Teor de P foliar e severidade de podridão radicular (nota de 0 a 5 , sendo $0=$ nenhuma raiz com podridão e $5=$ nenhuma raiz sadia) de plantas de limão 'Cravo' com nove meses de idade em quatro tratamentos de solo (benomyl, natural, radiação $\gamma$ com e sem filtrado de solo) dos sistemas de produção convencional e orgânico. As barras representam a média e o erro padrão. Em cada sistema de produção, médias seguidas das mesmas letras não diferem $(\mathrm{P} \leq 0,05)$ pelo teste de Student-Newman-Keuls 


\section{Experimento 2.}

Os fatores sistemas de produção, tratamento de solo e aplicação de benomyl tiveram efeitos sobre as plantas de limão 'Cravo', porém a infestação de $P$. parasitica não (Tabela 4). No sistema convencional, o tratamento radiação $\gamma$ apresentou maior crescimento de parte aérea sem aplicação de benomyl que com aplicação (Tabela 5). Sem considerar o sistema de produção, houve aumento na massa da matéria seca de raiz no tratamento de solo natural com benomyl (Tabela 6) e a massa da matéria seca de parte aérea, das plantas no solo natural com benomyl foi 19\% maior que das plantas no mesmo solo mas sem adição de benomyl (Tabela 5). Esse resultado foi confirmado pelo aumento de altura (Figura 3A) e pela diminuição no teor de nitrogênio nas plantas cultivadas nessas condições (efeito de diluição) (Tabela 6). No sistema orgânico, o efeito do benomyl foi mais evidente, diminuindo o teor de fósforo na parte aérea e também a colonização micorrízica nas plantas (Tabela 5). Ao contrário do observado no experimento 1, as plantas no solo irradiado apresentaram maior altura que as no solo natural, principalmente no sistema convencional (Figura 3B).

Sintomas de amarelecimento de folhas foram observados nas plantas no final do experimento, provavelmente causados por deficiência de nitrogênio, como foi detectado nas análises de tecido de parte aérea (Tabela 6). É possível que as plantas no sistema orgânico cresceram menos (Tabela 5) devido a menor disponibilidade desse nutriente (Tabela 7). 
Tabela 4. Teste $\mathrm{F}$ da análise de variância nas massas da matéria seca de parte aérea (MSA) e de raiz (MSR), teores de fósforo $(\mathrm{P})$ e nitrogênio $(\mathrm{N})$ na parte aérea, totais de fósforo (Ptot) e nitrogênio (Ntot) na parte aérea, colonização por FMAs nativos (COL) e severidade da podridão de raízes (SEV) em plantas de limão 'Cravo' de cinco meses de idade. Os efeitos principais foram: sistemas de produção (convencional e orgânico), tratamentos de solo (natural e radiação $\gamma$ com filtrado), benomyl (sem e com aplicação), P. parasitica (sem e com infestação artificial)

\begin{tabular}{lcccccccc}
\hline Fonte & MSA & MSR & P & Ptot & $\mathrm{N}$ & Ntot & COL & SEV \\
\hline Sistema de produção & $* * *$ & $* * *$ & $\mathrm{~ns}$ & $* * *$ & $* * *$ & $* * *$ & $* * *$ & $* *$ \\
(SP) & & & & & & & & \\
Tratamento de solo (TS) & $\mathrm{ns}$ & $* *$ & $* * *$ & $* *$ & $*$ & $\mathrm{~ns}$ & $* * *$ & $\mathrm{~ns}$ \\
SP x TS & $\mathrm{ns}$ & $\mathrm{ns}$ & $\mathrm{ns}$ & $\mathrm{ns}$ & $\mathrm{ns}$ & $\mathrm{ns}$ & $* * *$ & $* * *$ \\
Benomyl (Ben) & $\mathrm{ns}$ & $\mathrm{ns}$ & $* *$ & $\mathrm{~ns}$ & $\mathrm{~ns}$ & $\mathrm{~ns}$ & $* * *$ & $\mathrm{~ns}$ \\
SP x Ben & $\mathrm{ns}$ & $\mathrm{ns}$ & $* *$ & $\mathrm{~ns}$ & $\mathrm{~ns}$ & $\mathrm{~ns}$ & $* * *$ & $\mathrm{~ns}$ \\
TS x Ben & $* *$ & $*$ & $* * *$ & $\mathrm{~ns}$ & $* *$ & $\mathrm{~ns}$ & $* * *$ & $\mathrm{~ns}$ \\
SP x TS x Ben & $*$ & $\mathrm{~ns}$ & $* * *$ & $*$ & $\mathrm{~ns}$ & $\mathrm{~ns}$ & $* * *$ & $\mathrm{~ns}$ \\
$P$. parasitica & $\mathrm{ns}$ & $\mathrm{ns}$ & $\mathrm{ns}$ & $\mathrm{ns}$ & $\mathrm{ns}$ & $\mathrm{ns}$ & $\mathrm{ns}$ & $\mathrm{ns}$ \\
\hline $\begin{array}{l}\text { Níveis de significância, } \\
\text { Interações não apresentadas não foram significativas ou não aplicáveis }\end{array}$ &
\end{tabular}


Tabela 5. Massa da matéria seca de parte aérea (MSA), teor de fósforo (P) e fósforo total (Ptot) na parte aérea, colonização por FMAs nativos e severidade da podridão de raízes (SEV) em plantas de limão 'Cravo' de cinco meses de idade, cultivadas em solos oriundos dos sistemas de produção convencional (conv) e orgânico (org), em sua condição natural (nat) e tratados com radiação $\gamma(\gamma)$, e que receberam ou não aplicação de benomyl (ben+, ben-, respectivamente)

\begin{tabular}{lccccc}
\hline & $\begin{array}{c}\text { MSA } \\
(\mathrm{g})\end{array}$ & $\begin{array}{c}\text { P foliar } \\
\left(\mathrm{g} \mathrm{Kg}^{-1}\right)\end{array}$ & $\begin{array}{c}\text { Ptot } \\
(\mathrm{mg})\end{array}$ & $\begin{array}{c}\mathrm{COL}^{1} \\
(\%)\end{array}$ & $\begin{array}{c}\mathrm{SEV}^{2} \\
\end{array}$ \\
\hline conv nat ben- & $0,57 \pm 0,04(17) \mathrm{b}$ & $2,30 \pm 0,20(9) \mathrm{a}$ & $1,40 \pm 0,20(9) \mathrm{a}$ & $95,99 \pm 1,75(6) \mathrm{a}$ & $0,41 \pm 0,12(17) \mathrm{b}$ \\
conv nat ben + & $0,68 \pm 0,03(18) \mathrm{b}$ & $2,20 \pm 0,17(8) \mathrm{a}$ & $1,50 \pm 0,15(8) \mathrm{a}$ & $93,27 \pm 2,74(6) \mathrm{a}$ & $0,50 \pm 0,14(18) \mathrm{b}$ \\
conv $\gamma$ ben- & $0,88 \pm 0,06(8) \mathrm{a}$ & $1,38 \pm 0,03(8) \mathrm{b}$ & $1,21 \pm 0,07(8) \mathrm{a}$ & $5,22 \pm 2,15(6) \mathrm{b}$ & $0,62 \pm 0,37(8) \mathrm{b}$ \\
conv $\gamma$ ben + & $0,68 \pm 0,04(10) \mathrm{b}$ & $1,52 \pm 0,04(10) \mathrm{b}$ & $1,03 \pm 0,07(10) \mathrm{a}$ & $1,83 \pm 0,57(6) \mathrm{c}$ & $1,60 \pm 0,26(10) \mathrm{a}$ \\
org nat ben- & $0,25 \pm 0,01(16) \mathrm{a}$ & $2,87 \pm 0,28(10) \mathrm{a}$ & $0,79 \pm 0,11(10) \mathrm{a}$ & $90,04 \pm 4,12(6) \mathrm{a}$ & $0,62 \pm 0,23(16) \mathrm{a}$ \\
org nat ben+ & $0,29 \pm 0,02(15) \mathrm{a}$ & $1,33 \pm 0,07(7) \mathrm{b}$ & $0,44 \pm 0,04(7) \mathrm{b}$ & $19,94 \pm 10,34(6) \mathrm{b}$ & $0,60 \pm 0,23(15) \mathrm{a}$ \\
org $\gamma$ ben- & $0,30 \pm 0,03(10) \mathrm{a}$ & $1,47 \pm 0,03(10) \mathrm{b}$ & $0,44 \pm 0,05(10) \mathrm{b}$ & $4,38 \pm 2,38(6) \mathrm{b}$ & $0,20 \pm 0,13(10) \mathrm{a}$ \\
$\operatorname{org} \gamma$ ben + & $0,30 \pm 0,03(7) \mathrm{a}$ & $1,67 \pm 0,09(7) \mathrm{b}$ & $0,50 \pm 0,05(7) \mathrm{b}$ & $3,55 \pm 1,83(6) \mathrm{b}$ & $0,00 \pm 0,00(7) \mathrm{a}$ \\
\hline
\end{tabular}

Nas colunas, dentro de cada sistema de produção, médias seguidas das mesmas letras não diferem $(\mathrm{P} \leq 0,05)$ pelo teste de Student-Newman-Keuls. Apresentação: média \pm erro padrão (número de repetições)

${ }^{1}$ dados transformados para arcoseno $\sqrt{\mathrm{x}} / 100$

${ }^{2}$ dados transformados para $\sqrt{x}_{\mathrm{x}}+0,5$. Utilizou-se uma escala de notas $(0$ a 5$)$ para avaliação visual da severidade da doença 
Tabela 6. Massa da matéria seca de raiz (MSR) e teor de nitrogênio $(\mathrm{N})$ na parte aérea de plantas de limão 'Cravo' de cinco meses de idade, considerando a interação de tratamento de solo, natural (nat) e radiação $\gamma(\gamma)$ e aplicação de benomyl, sem (ben-) e com (ben+) aplicação

\begin{tabular}{lcc}
\hline & MSR & $\mathrm{N}$ \\
& $(\mathrm{g})$ & $\left(\mathrm{g} \mathrm{kg}^{-1}\right)$ \\
\hline nat ben- & $0,44 \pm 0,03(33)$ & $11,34 \pm 0,45(17) *$ \\
nat ben + & $0,54 \pm 0,03(33) *$ & $9,87 \pm 0,29(14)$ \\
$\gamma$ ben- & $0,64 \pm 0,07(18) \mathrm{ns}$ & $9,60 \pm 0,40(17)$ \\
$\gamma$ ben + & $0,59 \pm 0,05(17)$ & $10,33 \pm 0,43(16) \mathrm{ns}$
\end{tabular}

Nas colunas, dentro de cada tratamento de solo, $\left(^{*}\right)$ indica que há diferença entre médias e (ns) que não há diferença $(\mathrm{P} \leq 0,05)$ pelo teste $\mathrm{t}$. Apresentação: média \pm erro padrão (número de repetições)

Tabela 7. Massa da matéria seca de raiz (MSR), teor de nitrogênio $(\mathrm{N})$ e nitrogênio total (Ntot) na parte aérea de plantas de limão 'Cravo' de cinco meses de idade, cultivadas em solos de dois sistemas de produção, convencional e orgânico

\begin{tabular}{lccc}
\hline & MSR & $\mathrm{N}$ & Ntot \\
& $(\mathrm{g})$ & $(\mathrm{mg})$ \\
\hline Convencional & $0,67 \pm 0,03(53) *$ & $9,63 \pm 0,23(34)$ & $6,76 \pm 0,29(34) *$ \\
Orgânico & $0,38 \pm 0,02(48)$ & $11,07 \pm 0,33(30) *$ & $3,33 \pm 0,17(30)$
\end{tabular}

Nas colunas, $\left(^{*}\right)$ indica que há diferença entre médias $(\mathrm{P} \leq 0,01)$ pelo teste $\mathrm{F}$. Apresentação: média \pm erro padrão (número de repetições) 
A

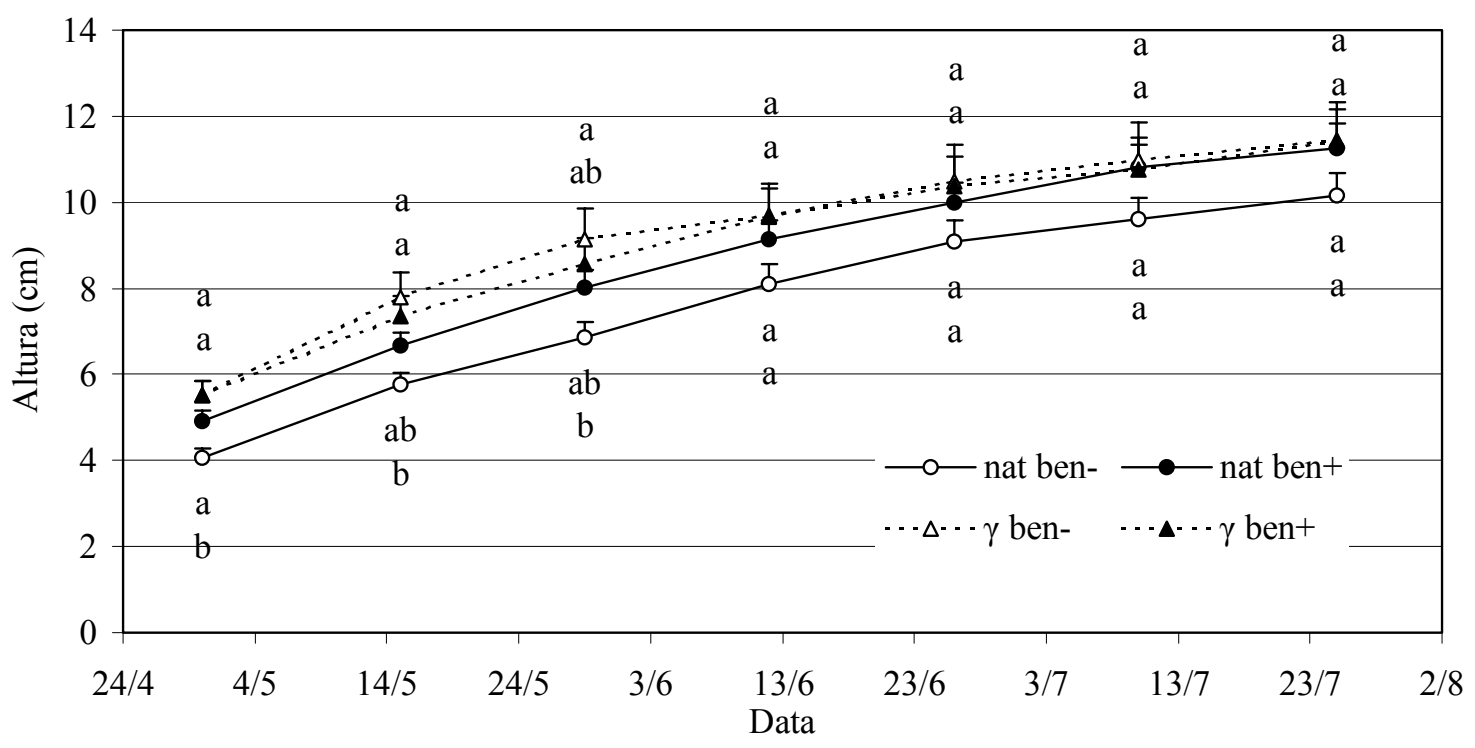

B

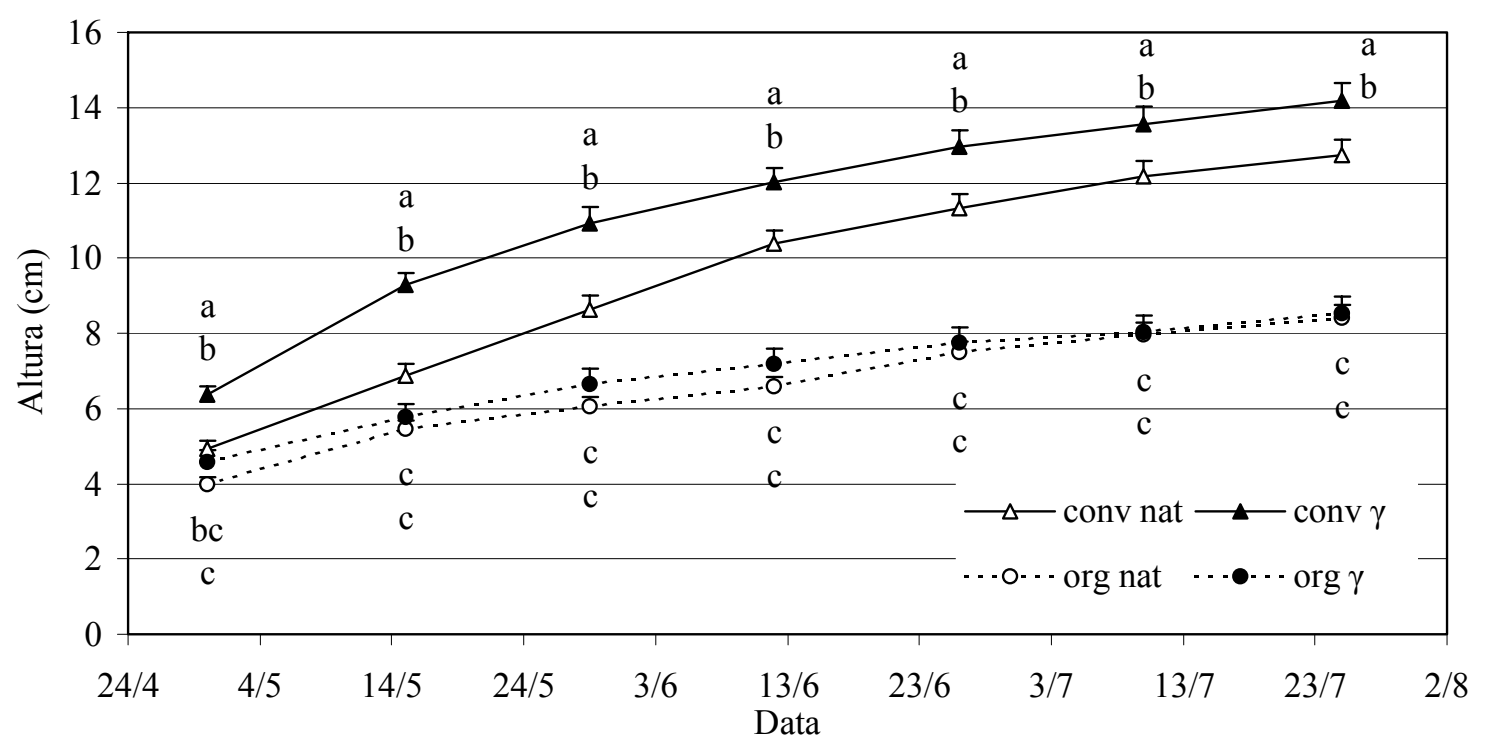

Figura 3 - Altura de planta, quinzenalmente, a partir de 30 de abril até 25 de julho de 2002. (A) mostra interação tratamento de solo e aplicação de benomyl; (B) mostra interação sistema de produção e tratamento de solo. As abreviaturas correspondem a: sistemas de produção (convencional=conv e orgânico=org), tratamentos de solo (natural=nat e irradiado= $=\gamma$ ); aplicação de benomyl ( $(\mathrm{sem}=$ ben- e com=bem + ). Médias seguidas das mesmas letras, em cada data, não diferem entre si $(\mathrm{P} \leq 0,05)$ pelo teste de Student-Newman-Keuls 


\section{Experimento 3.}

A interação dos fatores sistema de produção, tratamento de solo, aplicação de benomyl foi significativa na massa da matéria seca de parte aérea, porém foi maior o nível de significância no fator sistema de produção (Tabela 8). As plantas cultivadas nos solos do sistema orgânico tiveram 16\% menos de massa da matéria seca de parte aérea que as do convencional (Tabela 9). O mesmo ocorreu com o nitrogênio total de parte aérea (Tabelas 8 e 9). No entanto, a massa da matéria fresca de raiz não seguiu a mesma tendência. $\mathrm{O}$ fator significativo foi o tratamento de solo e indicou que as plantas micorrizadas (solo natural) possuíam maior sistema radicular que as plantas não micorrizadas (solo irradiado) (Tabela 9). Não foi possível detectar diferenças significativas na severidade de podridão de raiz (média de 0,5). Porém, a interação sistema de produção e tratamento de solo foi significativa para a recuperação de Phytophthora no laboratório, depois de desmontado o experimento. Nenhum esporângio foi observado nas iscas dos solos que receberam radiação $\gamma$. Porém, 96 e $47 \%$ das folhas avaliadas nas placas contendo solo natural do sistema orgânico e convencional, respectivamente, apresentavam esporângios do patógeno.

Com base nos limites de teores de nutrientes minerais em folhas de plantas cítricas descritos em Rodriguez (1980), algumas considerações sobre os resultados obtidos serão feitas a seguir. O teor de potássio na parte aérea das plantas foi em média 25,63 $\mathrm{g} \mathrm{Kg}^{-1}$, valor pertencente à faixa considerada excessiva para as plantas cítricas. Já o teor de cálcio foi deficiente, com valor médio de $7,38 \mathrm{~g} \mathrm{Kg}^{-1}$. Como o teor de magnésio (Tabela 10) também foi muito baixo, é possível que as deficiências de cálcio e magnésio tenham se acentuado pelo excesso de potássio, já que esse experimento recebeu fertilização com nitrato de potássio. O teor de manganês variou nos diferentes tratamentos dentro da faixa de deficiência e o teor de zinco de baixo a deficiente. O teor médio geral de ferro foi de $45 \mathrm{mg} \mathrm{Kg}^{-1}$, considerado baixo. A aplicação de benomyl diminuiu a colonização micorrízica nas plantas cultivadas no solo natural e também os teores de fósforo, magnésio, manganês, zinco e cobre na parte aérea dessas plantas (Tabelas 9 e 10). As plantas micorrizadas apresentaram teor de fósforo alto e teor de cobre adequado (Tabelas 9 e 10). 
Tabela 8. Teste F da análise de variância nas massas da matéria seca de parte aérea (MSA) e da matéria fresca de raiz (MFR), teores de macro e micronutrientes e totais de fósforo (Ptot) e nitrogênio (Ntot) na parte aérea, colonização por FMAs nativos (COL) e severidade da podridão de raízes (SEV) em plantas de limão 'Cravo' de sete meses de idade. Os efeitos principais foram: sistemas de produção (convencional e orgânico), tratamentos de solo (natural e radiação $\gamma$ com filtrado), benomyl (sem e com aplicação), P. parasitica (sem e com infestação artificial)

\begin{tabular}{|c|c|c|c|c|c|c|c|c|c|c|c|c|c|c|c|}
\hline Fonte & MSA & MFR & $\mathrm{N}$ & $\mathrm{K}$ & $\mathrm{P}$ & $\mathrm{Ca}$ & $\mathrm{Mg}$ & $\mathrm{Cu}$ & $\mathrm{Fe}$ & $\mathrm{Mn}$ & $\mathrm{Zn}$ & Ptot & Ntot & $\mathrm{COL}$ & SEV \\
\hline Sistema de produção (SP) & $* *$ & ns & ns & $* *$ & $* * *$ & $* * *$ & $* * *$ & ns & ns & $* * *$ & ns & $* * *$ & $* *$ & ns & ns \\
\hline Tratamento de solo (TS) & ns & $*$ & $* * *$ & ns & $* * *$ & $*$ & $* * *$ & $* * *$ & $*$ & $* *$ & $* * *$ & $* * *$ & ns & $* * *$ & ns \\
\hline $\mathrm{SP} \times \mathrm{TS}$ & ns & ns & ns & ns & ns & ns & ns & ns & ns & ns & $* *$ & ns & ns & ns & ns \\
\hline Benomyl (Ben) & ns & ns & ns & ns & $* * *$ & ns & $* *$ & $* * *$ & $\mathrm{~ns}$ & ns & ns & $* * *$ & ns & $* * *$ & ns \\
\hline SP x Ben & ns & ns & ns & ns & ns & $*$ & $*$ & $* *$ & ns & ns & ns & ns & ns & ns & ns \\
\hline TS x Ben & ns & ns & ns & ns & $* * *$ & ns & $* *$ & $* * *$ & $\mathrm{~ns}$ & $* * *$ & $* * *$ & $* * *$ & $\mathrm{~ns}$ & $* * *$ & ns \\
\hline SP x TS x Ben & $*$ & $*$ & ns & ns & ns & ns & ns & $* *$ & ns & ns & ns & ns & $*$ & ns & ns \\
\hline P. parasitica (Phy) & ns & ns & $*$ & ns & $*$ & ns & ns & ns & $*$ & $\mathrm{~ns}$ & ns & $* *$ & ns & ns & ns \\
\hline SP x Phy & ns & ns & $* *$ & ns & $\mathrm{ns}$ & ns & ns & ns & ns & $\mathrm{ns}$ & ns & ns & $\mathrm{ns}$ & ns & ns \\
\hline
\end{tabular}

Níveis de significância, * $(\mathrm{P} \leq 0,05), * *(\mathrm{P} \leq 0,01), * * *(\mathrm{P} \leq 0,001)$ e não significativo (ns)

Interações não apresentadas não foram significativas ou não aplicáveis 
Tabela 9. Massas da matéria seca de parte aérea (MSA) e da matéria fresca de raiz (MFR), total de nitrogênio (Ntot) e teor de cobre $(\mathrm{Cu})$ na parte aérea de plantas de limão 'Cravo' de sete meses de idade, cultivadas em solos oriundos dos sistemas de produção convencional (conv) e orgânico (org), em sua condição natural (nat) e tratados com radiação $\gamma(\gamma)$, e que receberam ou não aplicação de benomyl (ben+, ben-, respectivamente)

\begin{tabular}{lcccc}
\hline & $\begin{array}{c}\text { MSA } \\
(\mathrm{g})\end{array}$ & $\begin{array}{c}\text { MFR } \\
(\mathrm{g})\end{array}$ & $\begin{array}{c}\text { Ntot } \\
(\mathrm{mg})\end{array}$ & $\begin{array}{c}\mathrm{Cu} \\
\left(\mathrm{mg} \mathrm{Kg}^{-1}\right)\end{array}$ \\
\hline conv nat ben- & $1,52 \pm 0,08(12) \mathrm{a}$ & $2,59 \pm 0,13(12) \mathrm{a}$ & $30,47 \pm 0,8(9) \mathrm{a}$ & $7,92 \pm 0,23(9) \mathrm{a}$ \\
conv nat ben + & $1,45 \pm 0,14(9) \mathrm{a}$ & $2,39 \pm 0,14(9) \mathrm{a}$ & $28,79 \pm 2,86(9) \mathrm{a}$ & $6,12 \pm 0,35(9) \mathrm{b}$ \\
conv $\gamma$ ben- & $1,33 \pm 0,14(13) \mathrm{a}$ & $2,12 \pm 0,19(13) \mathrm{a}$ & $24,58 \pm 2,63(9) \mathrm{a}$ & $3,82 \pm 0,14(9) \mathrm{c}$ \\
conv $\gamma$ ben+ & $1,69 \pm 0,08(10) \mathrm{a}$ & $2,59 \pm 0,08(10) \mathrm{a}$ & $31,48 \pm 1,25(10) \mathrm{a}$ & $4,07 \pm 0,18(10) \mathrm{c}$ \\
org nat ben- & $1,25 \pm 0,08(14) \mathrm{a}$ & $2,65 \pm 0,15(14) \mathrm{a}$ & $25,42 \pm 1,42(10) \mathrm{a}$ & $9,85 \pm 0,68(10) \mathrm{a}$ \\
org nat ben+ & $1,34 \pm 0,08(10) \mathrm{a}$ & $2,5 \pm 0,13(10) \mathrm{a}$ & $25,56 \pm 1,34(10) \mathrm{a}$ & $5,46 \pm 0,35(10) \mathrm{b}$ \\
org $\gamma$ ben- & $1,27 \pm 0,09(14) \mathrm{a}$ & $2,45 \pm 0,13(14) \mathrm{a}$ & $24,59 \pm 1,35(10) \mathrm{a}$ & $3,55 \pm 0,10(10) \mathrm{c}$ \\
org $\gamma$ ben+ & $1,12 \pm 0,11(9) \mathrm{a}$ & $2,11 \pm 0,21(9) \mathrm{a}$ & $21,1 \pm 2,52(9) \mathrm{a}$ & $3,87 \pm 0,37(9) \mathrm{c}$ \\
\hline
\end{tabular}

Nas colunas, dentro de cada sistema de produção, médias seguidas das mesmas letras não diferem $(\mathrm{P} \leq 0,05)$ pelo teste de Student-Newman-Keuls. Apresentação: média \pm erro padrão (número de repetições) 
Tabela 10. Colonização por FMAs nativos (COL) e teores de nitrogênio $(\mathrm{N})$, magnésio $(\mathrm{Mg})$, manganês $(\mathrm{Mn})$, zinco $(\mathrm{Zn})$, fósforo $(\mathrm{P})$ e fósforo total (Ptot) na parte aérea de limão 'Cravo' de sete meses de idade, considerando a interação de tratamento de solo, natural (nat) e radiação $\gamma(\gamma)$ e aplicação de benomyl, sem (ben-) e com (ben+) aplicação

\begin{tabular}{lllll}
\hline & \multicolumn{1}{c}{ nat ben- } & \multicolumn{1}{c}{ nat ben +} & \multicolumn{1}{c}{$\gamma$ ben- } & \multicolumn{1}{c}{$\gamma$ ben +} \\
\hline $\mathrm{COL}^{1}(\%)$ & $99,53 \pm 0,11(12) *$ & $63,84 \pm 7,28(12)$ & $0,27 \pm 0,14(12) \mathrm{ns}$ & $0,13 \pm 0,08(12)$ \\
$\mathrm{N}\left(\mathrm{g} \mathrm{kg}^{-1}\right)$ & $20,85 \pm 0,65(19) \mathrm{ns}$ & $19,54 \pm 0,35(19)$ & $18,23 \pm 0,52(19) \mathrm{ns}$ & $18,73 \pm 0,63(19)$ \\
$\mathrm{Mg}\left(\mathrm{g} \mathrm{kg}^{-1}\right)$ & $0,94 \pm 0,03(19) *$ & $0,77 \pm 0,03(19)$ & $0,72 \pm 0,02(19) \mathrm{ns}$ & $0,74 \pm 0,03(19)$ \\
$\mathrm{Mn}\left(\mathrm{mg} \mathrm{kg}^{-1}\right)$ & $13,52 \pm 0,77(19) *$ & $11,00 \pm 0,5(19)$ & $10,10 \pm 0,58(19) \mathrm{ns}$ & $11,63 \pm 0,54(19)$ \\
$\mathrm{Zn}\left(\mathrm{mg} \mathrm{kg}^{-1}\right)$ & $20,39 \pm 1,12(19) *$ & $15,65 \pm 0,47(19)$ & $10,25 \pm 0,63(19) \mathrm{ns}$ & $12,52 \pm 1,23(19)$ \\
$\mathrm{P}\left(\mathrm{g} \mathrm{kg}^{-1}\right)$ & $2,22 \pm 0,41(19) *$ & $1,12 \pm 0,30(19)$ & $0,73 \pm 0,13(19) \mathrm{ns}$ & $0,75 \pm 0,12(19)$ \\
Ptot (mg) & $3,07 \pm 0,22(19) *$ & $1,60 \pm 0,16(19)$ & $1,00 \pm 0,08(19) \mathrm{ns}$ & $1,09 \pm 0,09(19)$ \\
\hline
\end{tabular}

Nas linhas, dentro de cada tratamento de solo, $\left({ }^{*}\right)$ indica que há diferença entre médias e (ns) que não há diferença $(\mathrm{P} \leq 0,05)$ pelo teste t. Apresentação: média \pm erro padrão (número de repetições)

${ }^{1}$ dados foram transformados para arcoseno $\sqrt{ } \mathrm{x} / 100$ para análise

\subsection{Discussão}

Nos experimentos 1 e 2, a aplicação de benomyl no solo natural dos sistemas convencional e orgânico provocou resposta positiva no crescimento das plantas de limão 'Cravo' e diminuição dos teores de fósforo na parte aérea. Esses resultados indicam que o fungicida afetou os fungos micorrízicos nativos e diminuiu o custo da colonização para as plantas em simbiose, como ocorreu nos experimentos de Graham \& Eissenstat (1998). Segundo esses autores, o benomyl não funcionou como regulador do crescimento quando aplicado em plantas cítricas não micorrizadas, nem aumentou os teores de nitrogênio foliar ou outros macro e micronutrientes. Nos experimentos 2 e 3 , as plantas crescidas nos solos irradiados com e sem aplicação de benomyl apresentaram teores de nutrientes similares (Tabelas 6 e 10), confirmando as observações descritas anteriormente. No entanto, no experimento 1, não se pode descartar a possibilidade de alguma influência do nitrogênio no crescimento das plantas tratadas com benomyl, pois 
essas tiveram aumento no teor de nitrogênio foliar em relação às plantas do solo natural. Em um experimento em vasos em casa de vegetação, de longa duração (próximo de um ano), Cade-Menun \& Berch (1997) também obtiveram aumento no teor de nitrogênio foliar em plantas de Thuja plicata tratadas com benomyl e levantaram três hipóteses: aporte direto do nitrogênio que o benomyl possui em sua molécula, aporte indireto de nitrogênio por morte de células microbianas e efeito sobre processos de nitrificação no solo. Considerando os limites nutricionais estabelecidos para folhas de plantas cítricas (Rodriguez, 1980), o teor de nitrogênio foliar das plantas cultivadas em solo natural sem benomyl não foi deficiente (Tabela 3) e propõe-se que o efeito principal do fungicida tenha sido a mudança na relação custo/benefício que envolve a simbiose planta-FMA.

A aplicação de benomyl nem sempre diminuiu a colonização micorrízica pelos fungos nativos dos sistemas de produção convencional e orgânico, porém, em geral reduziu a absorção de fósforo, indicando ter produzido algum efeito negativo sobre o micélio externo e, ou, o funcionamento da associação micorrízica. Já foi demonstrado que o benomyl inibe o transporte de fósforo nas hifas dos fungos micorrízicos (Larsen et al., 1996) e reduz o número de arbúsculos e hifas internas e externas vivos (Sukarno et al., 1993). Kahiluoto \& Vestberg (2000) relataram que o micélio externo correlacionouse melhor que a colonização radicular com o efeito do benomyl no crescimento e absorção de fósforo. Mesmo o benomyl sendo um fungicida sistêmico, o fungo está mais protegido dentro das raízes e o controle da colonização interna é parcial, permanecendo certos níveis de colonização (Sukarno et al., 1993; Cade-Menun \& Berch, 1997; Graham \& Eissenstat, 1998; Kahiluoto et al., 2000). Nos experimentos 2 e 3, nos quais foram utilizados vasos de pequeno volume, foram observados efeitos negativos sobre a colonização radicular, provavelmente devido ao maior contato do fungicida com as raízes de limão 'Cravo', confirmando a necessidade de uma distribuição eficiente do produto no solo próximo às raízes (Graham \& Eissenstat, 1998). Além desse aspecto, diferentes solos podem regular de formas distintas o efeito do benomyl sobre os FMAs. Ao contrário dos resultados obtidos por Kahiluoto et al. (2000), as respostas à aplicação de benomyl no presente estudo variaram com os tipos de manejo, convencional e orgânico (Tabelas 2, 4 e 8). 
No experimento 2, ao contrário do observado no experimento 1, as plantas no solo irradiado apresentaram maior altura que as no solo natural, principalmente no sistema convencional. Sugere-se que essa diferença se deva ao tipo de semeadura. No experimento 1 foi feito transplante e no 2, semeadura direta. A colonização por FMAs nativos nas plantas recém germinadas pode ter atrasado o crescimento das plantas micorrizadas pelo alto custo de formação e manutenção da simbiose (Peng et al., 1993). No sistema orgânico, a deficiência de nitrogênio pode ter impedido que as plantas em geral se comportassem melhor, como ocorreu no sistema convencional.

A severidade de podridão de raízes, no experimento 1, foi maior nas plantas cultivadas no solo do sistema convencional que receberam benomyl (Figura 2). Duas hipóteses são propostas: benomyl predispôs as plantas a $P$. parasitica e, ou, foi prejudicial a microrganismos antagônicos ao patógeno no solo. Sugerem-se duas possíveis explicações para o aumento da predisposição ao patógeno. Por um lado, as plantas de limão 'Cravo' no tratamento com benomyl cresceram mais que nos outros tratamentos (Tabela 3) e plantas cítricas mais vigorosas, em geral, apresentam menor resistência à gomose de Phytophthora (Mello et al., 1971). Por outro lado, o efeito negativo do fungicida sobre os FMAs pode ter permitido o maior desenvolvimento do patógeno nas raízes. Em raízes de tomate, os sintomas de necrose e o número de hifas de P. parasitica no córtex radicular foram reduzidos pela presença de Glomus mosseae (Cordier et al., 1996) e, em plantas cítricas, as espécies G. mosseae e Gigaspora margarita também aumentaram a resistência das plantas a esse patógeno (Davis \& Menge, 1981). Apesar de o benomyl provocar poucos efeitos colaterais na microbiota e nos processos bioquímicos do solo comparado a outros fungicidas (Chen et al., 2001) e ter sido recomendado como método mais apropriado para obtenção de testemunha não micorrizada para comunidade de FMAs nativos (Kahiluoto et al., 2000), seus efeitos nocivos sobre outros microrganismos do solo podem ocorrer. Sukarno et al (1993) observaram reduções no micélio ativo em vasos de cebola não micorrizada que receberam benomyl e alertaram para os possíveis efeitos negativos desse fungicida sobre fungos saprofíticos. 
Foi evidente que, nas condições do experimento 3, a comunidade de fungos micorrízicos nativos tanto do sistema de produção convencional como orgânico estava contribuindo para a absorção do fósforo, magnésio, manganês, zinco e cobre (Tabelas 9 e 10). Rego (2000) também observou que os FMAs nativos de solos de pomar de laranja 'Pêra' enxertada em limão 'Cravo' de sete anos de idade na Bahia, sujeitos a diferentes práticas agrícolas, promoveram um melhor estado nutricional de plantas de limão 'Cravo' em experimento em casa de vegetação. É conhecido que os fungos micorrízicos podem aumentar a absorção de nutrientes de baixa mobilidade no solo, como o fósforo e os micronutrientes zinco e cobre (Silveira, 1992; Moreira \& Siqueira, 2002), e também proteger as plantas contra toxicidade de manganês, diminuindo seu teor nos tecidos de diferentes espécies de plantas (Nogueira \& Cardoso, 2000; Moreira-Souza \& Cardoso, 2002). No presente estudo, o efeito da simbiose micorrízica sobre a absorção de manganês foi distinto, provavelmente, devido a que os teores desse nutriente na parte aérea de limão 'Cravo' estiveram dentro da faixa considerada deficiente. Com exceção de potássio, os níveis de macro e micronutrientes nos solos de campo de ambos os sistemas de produção eram satisfatórios (Tabela 1). Os baixos teores de diversos nutrientes na parte aérea apareceram nos experimentos 2 e 3 pelo reduzido volume dos vasos utilizados. Aparentemente, a fertilização aplicada ao experimento 3 não supriu as necessidades das plantas e possivelmente gerou antagonismos entre nutrientes. As condições de campo foram melhor representadas no experimento 1, com vasos de maior capacidade e nenhuma fertilização complementar.

\subsection{Conclusões}

Muitas interações do benomyl com os solos dos sistemas de produção ocorreram. Portanto, a radiação $\gamma$ foi mais adequada que a aplicação do fungicida benomyl na obtenção de uma testemunha satisfatória para experimento de controle biológico de $P$. parasitica por FMAs nativos de pomares de plantas cítricas, com diferentes tipos de manejo. A utilização de volumes reduzidos de solo não foi adequada para a realização desse tipo de experimento. 


\section{INTERAÇÃO DE Phytophthora parasitica E FUNGOS MICORRÍZICOS ARBUSCULARES NATIVOS EM CITROS: UM ESTUDO DE MICROCOSMO}

\section{Resumo}

Entender as complexas interações microbianas nos solos sujeitos a diferentes manejos agrícolas é fundamental para o sucesso do controle biológico no campo. Com o objetivo de estudar a interação de Phytophthora parasitica e as comunidades de fungos micorrízicos arbusculares (FMAs) nativos de sistemas de produção convencional e orgânico de plantas cítricas foi realizado um experimento com plantas de limão 'Cravo', semeadas diretamente em microcosmos com solo coletado no final do verão no Estado de São Paulo. A comunidade de FMAs nativos presente no solo natural, de ambos os sistemas de produção, proporcionou uma alta colonização radicular, o que foi refletido no maior teor de fósforo foliar em plantas micorrizadas. Porém, o solo natural do sistema orgânico foi desfavorável ao crescimento das plantas, resultando nas menores massas de matéria seca de parte aérea, de raiz e total. A podridão de raízes observada nos tratamentos com solo natural, mesmo sem a infestação posterior de P. parasitica, pode ter sido causada por Phytophthora e Pythium provenientes do campo, ou por outros patógenos não avaliados. São discutidas as possíveis relações entre os fatores climáticos da época de coleta do solo no campo e do desenvolvimento do experimento em casa de vegetação, os tipos de semeadura e a severidade da podridão radicular nas plantas cultivadas em solos dos sistemas de produção com manejo convencional e orgânico. 


\section{INTERACTION BETWEEN Phytophthora parasitica AND INDIGENOUS ARBUSCULAR MYCORRHIZAL FUNGI IN CITRUS: A MICROCOSM STUDY Summary}

It is very important to understand the complex microbial interactions in soil

under different farming systems to achieve biological control on field. With the objective of studying interaction between Phytophthora parasitica and the indigenous arbuscular mycorrizal fungi (AMF) communities in conventional and organic citrus agroecosystems, a microcosm experiment with 'Rangpur' lime and soil collected in field at the end of summer, in São Paulo State, was carried out. The AMF community in natural soil of both agroecosystems provided high root colonization levels, which were reflected in higher phosphorus foliar levels in mycorrhizal plants. However, the natural soil of the organic system was unfavourable to plant growth, resulting in lower shoot, root and total dry weights. The root rot observed in the natural soil treatments, even in those without the subsequent inoculation of $P$. parasitica, could be caused by Phytophthora and Pythium from field, or by other pathogens not evaluated. The possible relationships among climatic factors at the moment of soil collection and during the development of the experiment in greenhouse, the sawing type and the root rot severity of plants cultivated in soils of the conventional and organic farming are discussed.

\subsection{Introdução}

O estudo de antagonistas isolados e introduzidos em condições controladas é muito importante, porém, trabalhos sobre a relação de práticas culturais com controle biológico natural (antagonistas residentes) também devem ser prioridades de pesquisa para o avanço da implementação do controle biológico no campo (Cook, 1993).

Já foi demonstrado que isolados de fungos micorrízicos arbusculares (FMAs) podem aumentar a resistência de plantas cítricas a Phytophthora parasitica (Davis \& Menge, 1981). No entanto, estudos com plantas cítricas envolvendo comunidade de FMAs e esse patógeno não foram encontrados na literatura. No cultivo de ervilha, experimento de campo mostrou que FMAs nativos diminuíram a produção de oosporos do patógeno Aphanomyces euteiches nas raízes das plantas (Bødker et al., 2002). Plantas 
de ciclo curto podem ser mais facilmente manejadas em experimentos de campo comparadas às plantas perenes, como são as plantas cítricas. Portanto, metodologias que simulem as condições de campo na casa de vegetação podem ser uma alternativa a esse problema. A técnica de microcosmo, na qual solo do campo é utilizado diretamente em experimentos em casa de vegetação ou laboratório, tem sido utilizada para avaliar efeitos de agrotóxicos sobre atividade microbiana e processos ecológicos no solo (Chen et al., 2001) e poderia ser uma opção. Porém, épocas de coleta do solo em campo e realização dos experimentos em casa de vegetação, sistema de semeadura, entre outros fatores, podem provavelmente influenciar os resultados sobre as interações patógeno-fungos micorrízicos.

Esse trabalho teve como objetivo estudar a interação de $P$. parasitica e as comunidades de FMAs nativos de sistemas de produção convencional e orgânico de plantas cítricas em microcosmos com solo coletado no período das águas (final do verão no Estado de São Paulo) e semeadura direta de plantas de limão 'Cravo'.

\subsection{Material e Métodos}

\section{Solo e comunidade de FMAs nativos}

Duas áreas vizinhas de produção de plantas cítricas foram escolhidas para a coleta dos solos utilizados nesse experimento. Ambas as propriedades possuem cultivos de laranja 'Pêra' (Citrus sinensis) sobre limão 'Cravo' (Citrus limonia), de aproximadamente 12 anos de idade, plantados em solo do tipo Neossolo Quartzarênico e estão situadas na divisa dos municípios Piracicaba-Botucatu, SP (aproximadamente aos $45 \mathrm{Km}$ de Piracicaba pela via para Anhembi). Diferem pelo tipo de manejo do sistema de produção, um convencional e outro orgânico. Amostragens foram feitas em 15 árvores por sistema, a cada duas linhas do cultivo, compostas por quatro pontos ao redor de cada árvore, de 0 a $20 \mathrm{~cm}$ de profundidade. Posteriormente, as amostras de cada sistema de manejo foram misturadas e peneiradas $(2 \mathrm{~mm})$ para homogeneização e retirada do excesso de raízes. O solo foi coletado no mesmo mês em que se instalou o experimento (março 2002). 
Metade do solo de cada amostra composta foi submetida à irradiação com raios $\gamma$ (6 KGy) e a outra metade mantida nas condições originais, contendo a comunidade de FMAs nativos (solo natural). Em seguida, foram enviadas amostras para análise de fertilidade no Laboratório de Análise de Solo e Planta do IAC, Campinas (Tabela 1).

Tabela 1. Análise de fertilidade de solo dos sistemas de produção orgânico e convencional de plantas cítricas, em sua condição natural e após irradiação

\begin{tabular}{|c|c|c|c|c|c|c|}
\hline \multicolumn{3}{|c|}{ Determinações } & \multicolumn{4}{|c|}{ Sistemas de produção } \\
\hline \multirow[t]{2}{*}{ Sigla } & \multirow[t]{2}{*}{ Descrição } & \multirow[t]{2}{*}{ Unidade } & \multicolumn{2}{|c|}{ Orgânico } & \multicolumn{2}{|c|}{ Convencional } \\
\hline & & & Natural & Irradiado & Natural & Irradiado \\
\hline M.O. & Matéria Orgânica & $\mathrm{g} \mathrm{m}^{-3}$ & 15 & 18 & 12 & 16 \\
\hline pH & Solução $\mathrm{CaCl}_{2}$ & & 6,3 & 6,8 & 5,5 & 5,6 \\
\hline $\mathbf{P}$ & Fósforo Resina & $m g \mathrm{dm}^{-3}$ & 50 & 48 & 43 & 44 \\
\hline $\mathbf{K}$ & Potássio & $\mathrm{mmol}_{\mathrm{c}} \mathrm{dm}^{-3}$ & 0,3 & 0,6 & 1,0 & 0,9 \\
\hline Ca & Cálcio & $\mathrm{mmol}_{\mathrm{c}} \mathrm{dm}^{-3}$ & 59 & 61 & 26 & 40 \\
\hline Mg & Magnésio & $\mathrm{mmol}_{\mathrm{c}} \mathrm{dm}^{-3}$ & 23 & 32 & 12 & 24 \\
\hline $\mathbf{H}+\mathbf{A l}$ & Ac. Potencial & $\mathrm{mmol}_{\mathrm{c}} \mathrm{dm}^{-3}$ & 8 & 8 & 16 & 15 \\
\hline S.B. & Soma de Bases & $\mathrm{mmol}_{\mathrm{c}} \mathrm{dm}^{-3}$ & 82,3 & 93,6 & 39,0 & 64,9 \\
\hline CTC & Cap. Troca Catiônica & $\mathrm{mmol}_{\mathrm{c}} \mathrm{dm}^{-3}$ & 90,1 & 101,4 & 55,4 & 79,7 \\
\hline $\mathbf{V}$ & Saturação de Bases & $\%$ & 91 & 92 & 70 & 81 \\
\hline B & Boro & $\mathrm{mg} \mathrm{dm}{ }^{-3}$ & 0,12 & 0,18 & 0,14 & 0,19 \\
\hline Cu & Cobre & $\mathrm{mg} \mathrm{dm} \mathrm{dm}^{-3}$ & 2,9 & 3,8 & 6,3 & 9,3 \\
\hline Fe & Ferro & $m g \mathrm{dm}^{-3}$ & 12 & 22 & 41 & 62 \\
\hline Mn & Manganês & $\mathrm{mg} \mathrm{dm}^{-3}$ & 10,0 & 15,6 & 4,4 & 6,0 \\
\hline Zn & Zinco & $\mathrm{mg} \mathrm{dm}^{-3}$ & 7,3 & 8,7 & 2,2 & 3,0 \\
\hline
\end{tabular}

Métodos de extração: P - resina; B - água quente; $\mathrm{Cu}, \mathrm{Fe}, \mathrm{Mn}, \mathrm{Zn}$ - DTPA

Inóculo de $P$. parasitica

O isolado de P. parasitica foi cedido pela Clínica Fitopatológica do Centro APTA Citros Sylvio Moreira, Cordeirópolis, SP. Foi preservado a temperatura ambiente em água destilada (método de Castellani) e por repicagens periódicas em meio de cultura. O meio de cultura recomendado por May \& Kimati (1997) foi utilizado tanto para a preservação como para o crescimento e esporulação do patógeno: $50 \mathrm{~g}$ de cenoura, $10 \mathrm{~g}$ de dextrose e $20 \mathrm{~g}$ de agar para $1 \mathrm{~L}$ de meio. Cenoura crua foi batida no liquidificador antes de ser adicionada ao meio.

Para a infestação do solo com $P$. parasitica, foi realizado o procedimento descrito em Araújo (1998), com algumas modificações. Discos de 7 mm de diâmetro 
foram retirados da borda de colônias de sete dias de idade crescidas no escuro a temperatura de $26-28{ }^{\circ} \mathrm{C}$ e passados para placas de Petri (Pyrex) esterilizadas. Cada placa recebeu 10 discos de micélio, $25 \mathrm{~mL}$ de água destilada esterilizada e 15 discos de 7 mm de diâmetro de folhas de limão 'Cravo'. Para que a produção de esporângios fosse estimulada nos discos de micélio e nas bordas das folhas, as placas foram mantidas em luz fluorescente contínua por uma semana, a temperaturas médias mínimas e máximas de 22 e $32{ }^{\circ} \mathrm{C}$, respectivamente. Paralelamente, 12 colônias de 15 dias de idade, crescidas em condições similares às já descritas, foram utilizadas para a preparação de 2 L de uma suspensão de hifas. No liquidificador, foi batido micélio raspado de oito dessas colônias e quatro colônias inteiras, inclusive com meio. Em cada vaso correspondente a esse tratamento, com um bastão de vidro, cinco orifícios foram feitos no solo ao redor de cada planta, onde foram depositados dois discos de folha e três de micélio. Depois, $30 \mathrm{~mL}$ da suspensão de hifas foram aplicados. Nos demais vasos, também foram feitos os orifícios, porém só receberam água. Durante os primeiros três dias depois da infestação, os vasos foram irrigados e a água mantida nos pratos.

\section{Experimento em casa de vegetação}

O experimento foi em arranjo fatorial $2^{3}$ : solo dos dois sistemas de produção; solo irradiado e natural; com e sem infestação artificial de $P$. parasitica. $\mathrm{O}$ desenho experimental foi inteiramente casualisado, com 12 repetições.

Vasos plásticos de $1 \mathrm{~L}$ foram utilizados. Primeiramente, foi colocada brita no fundo do vaso e depois $800 \mathrm{~mL}$ de solo, irradiado ou não, proveniente de cada sistema de produção. Para restabelecimento da microbiota nativa, exceto fungos micorrízicos, $100 \mathrm{~mL}$ de filtrado de solo do sistema convencional e orgânico foram aplicados nos vasos que receberam seus respectivos solos irradiados. Para preparação do filtrado, uma suspensão de $500 \mathrm{~mL}$ de solo natural em água esterilizada foi agitada manualmente, passada na peneira de $45 \mu \mathrm{m}$ e completada para $3 \mathrm{~L}$ de filtrado. Quatro sementes de limão 'Cravo', previamente tratadas com hipoclorito de sódio $2-2,5 \%$ por $10 \mathrm{~min}$ e lavadas em água corrente, foram plantadas por vaso. Após a germinação, foi feito desbaste, mantendo uma planta por vaso. Quatro meses e meio depois da semeadura, o 
solo foi infestado com P. parasitica. Durante todo o experimento, os vasos foram irrigados com água fervida

O experimento foi realizado de 18 de março a 1 de outubro de 2002, em casa de vegetação, no Instituto Agronômico - IAC, no Centro Experimental Central, Campinas, SP. As médias das temperaturas mínimas e máximas diárias dentro da casa de vegetação durante esse período estão apresentadas na Figura 1.

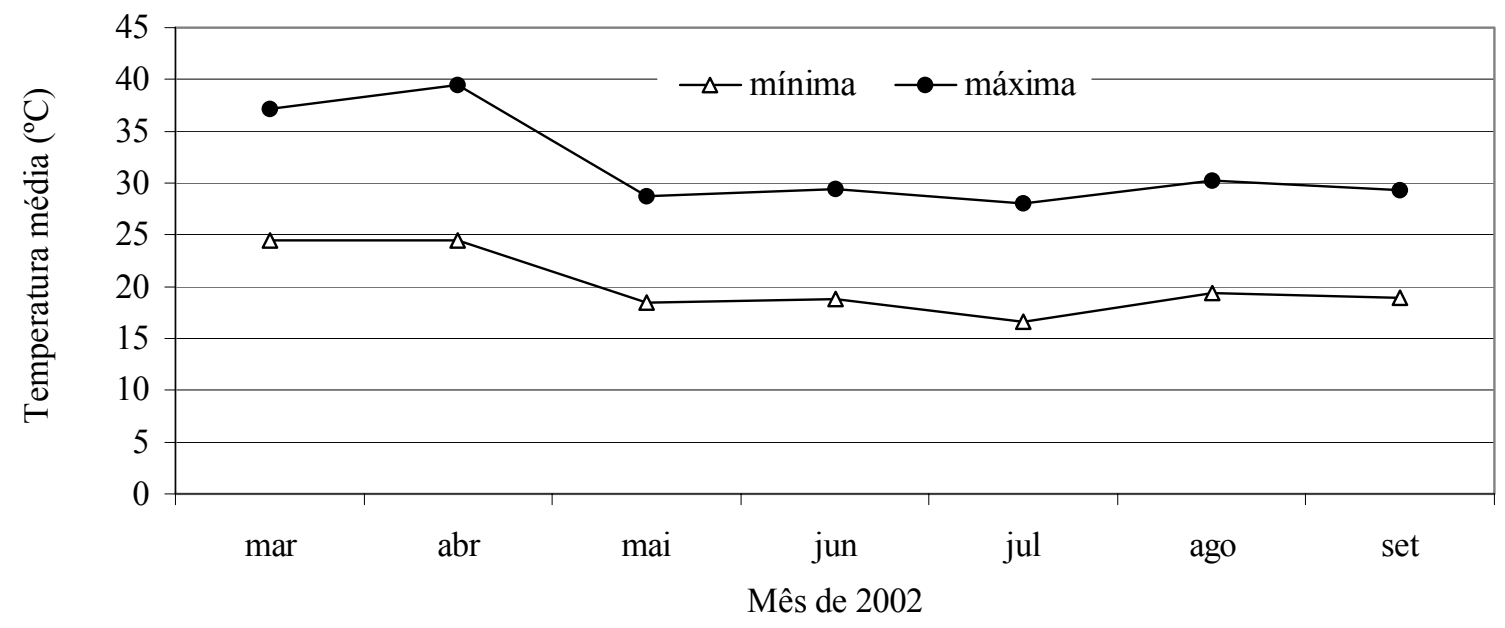

Figura 1 - Médias das temperaturas mínimas e máximas diárias de março a setembro de 2002 na casa de vegetação, Centro Experimental Central, Campinas, SP

\section{Variáveis avaliadas}

A partir do segundo mês da semeadura, a altura de plantas foi medida quinzenalmente até o final do experimento, ou seja, oito semanas depois da infestação com o patógeno. Nesse momento, foi atribuída nota de 0 a 5 para a severidade da podridão de raízes: $0=$ sem sintoma a $5=$ raiz completamente necrosada (Pozo et al., 2002) e a massa da matéria fresca de raiz foi obtida antes e depois da retirada de uma parte da raiz, que foi guardada em álcool $50 \%$ para posterior determinação da colonização micorrízica.

Tanto a parte aérea das plantas quanto a parte restante de raízes foram secas em estufa a $60{ }^{\circ} \mathrm{C}$ até peso constante. Assim, foram obtidas, diretamente, a massa da matéria seca de parte aérea e, por meio de cálculo, a massa da matéria seca de raiz. A resposta micorrízica foi obtida pela seguinte fórmula: (MSA+MSR de planta micorrizada/ 
MSA+MSR de planta não micorrizada) -1 (Graham \& Abbott, 2000), a partir de médias e sem aplicação estatística. O fósforo foliar foi determinado por colorimetria, pelo método de molibidato-vanadato (Bataglia et al., 1983).

As estruturas dos FMAs nas raízes foram coloridas com base no método desenvolvido por Vierheilig et al. (1998). As raízes guardadas em álcool foram lavadas em água corrente, clareadas em $\mathrm{KOH} 10 \%$ em banho maria fervendo por 15 min e novamente lavadas. Em seguida, colocadas em uma solução a $5 \%$ de tinta de caneta (Parker, preta) e vinagre branco de cozinha puro (4\% de ácido acético) por 3-4 min em banho maria fervendo. Depois de lavados em água corrente, 30 segmentos de $1 \mathrm{~cm}$ de raiz colorida por planta foram montados em lâminas e observados em microscópio para a determinação da porcentagem de colonização micorrízica (Giovannetti \& Mosse, 1980).

\section{Análise estatística}

Foi utilizado o programa SAS para análise estatística. Depois de realizada a análise de variância de cada variável para os três fatores e interações (procedimento Modelos Lineares Generalizados- GLM), o teste de Student-Newman-Keuls foi aplicado para as comparações de médias. Dados de colonização e severidade foram transformados para arcoseno $\sqrt{x}_{\mathrm{X}} / 100 \mathrm{e} \sqrt{\mathrm{X}}_{\mathrm{X}}+0,5$, respectivamente, para serem analisados.

\subsection{Resultados}

Exceto para relação massa da matéria seca de raiz/massa da matéria seca de parte aérea, a interação sistema de produção e tratamento de solo foi altamente significativa para todas as variáveis analisadas. Não houve efeito da infestação com $P$. parasitica sobre nenhuma variável (Tabela 2).

A comunidade de FMAs nativos do solo natural de ambos os sistemas de produção proporcionou uma alta colonização radicular, o que refletiu no maior teor de fósforo foliar nas plantas micorrizadas (Tabela 3). Porém, o solo natural do sistema orgânico foi desfavorável ao crescimento das plantas, resultando nas menores massas de 
matéria seca de parte aérea, de raiz e total (Tabela 3). Conseqüentemente, a resposta micorrízica foi negativa no sistema orgânico $(-0,79)$. Nesse sistema, as plantas no solo natural tiveram seu crescimento comprometido desde o inicio do seu desenvolvimento (Figura 2). Isso não ocorreu no sistema convencional. As plantas, nos três primeiros meses de idade, nos dois tratamentos de solo, cresceram de maneira similar e, posteriormente, começaram a apresentar maior altura no solo natural (Figura 2).

Tabela 2. Teste $\mathrm{F}$ da análise de variância nas massas da matéria seca de parte aérea (MSA), de raiz (MSR) e total (MSA+MSR), relação MSR/MSA, teor de fósforo foliar (P), fósforo foliar total (Ptot), colonização por FMAs nativos (COL) e severidade da podridão de raízes (SEV) de plantas de limão 'Cravo' de seis meses e meio de idade. Os fatores são sistemas de produção (convencional e orgânico), tratamentos de solo (radiação $\gamma$ e natural) e níveis de infestação de $P$. parasitica (sem e com infestação artificial)

\begin{tabular}{lcccccccc}
\hline Fatores e interações & MSA & MSR & MSA+MSR & MSR/MSA & P & Ptot & COL & SEV \\
\hline Sistema de produção (SP) & $* * *$ & $* * *$ & $* * *$ & $\mathrm{~ns}$ & $* * *$ & $* * *$ & $\mathrm{~ns}$ & $* * *$ \\
Tratamento de solo (TS) & $* * *$ & $\mathrm{~ns}$ & $* * *$ & $* * *$ & $* * *$ & $* * *$ & $* * *$ & $* * *$ \\
P. parasitica (Phy) & $\mathrm{ns}$ & $\mathrm{ns}$ & $\mathrm{ns}$ & $\mathrm{ns}$ & $\mathrm{ns}$ & $\mathrm{ns}$ & $\mathrm{ns}$ & $\mathrm{ns}$ \\
SPxTS & $* * *$ & $* * *$ & $* * *$ & $\mathrm{~ns}$ & $* * *$ & $* * *$ & $* * *$ & $* *$ \\
\hline
\end{tabular}

Níveis de significância, * $(\mathrm{P} \leq 0,05), * *(\mathrm{P} \leq 0,01), * * *(\mathrm{P} \leq 0,001)$ e não significativo (ns). Interações não apresentadas não foram significativas ou não aplicáveis 
Tabela 3. Massas da matéria seca de parte aérea (MSA) e de raiz (MSR), teor de fósforo foliar (P), fósforo foliar total (Ptot), colonização por FMAs nativos (COL) e severidade de podridão de raízes (SEV) de plantas de limão 'Cravo' de seis meses e meio de idade em dois tratamentos de solo (radiação $\gamma$ e natural) dos sistemas de produção convencional e orgânico

\begin{tabular}{lcccc}
\hline & $\begin{array}{c}\text { Convencional } \\
\text { radiação } \gamma\end{array}$ & $\begin{array}{c}\text { Convencional } \\
\text { natural }\end{array}$ & $\begin{array}{c}\text { Orgânico } \\
\text { radiação } \gamma\end{array}$ & $\begin{array}{c}\text { Orgânico } \\
\text { natural }\end{array}$ \\
\hline MSA (g) & $1,32 \pm 0,07(22) \mathrm{a}$ & $1,33 \pm 0,04(20) \mathrm{a}$ & $1,35 \pm 0,10(21) \mathrm{a}$ & $0,24 \pm 0,04(20) \mathrm{b}$ \\
MSR (g) & $1,02 \pm 0,05(22) \mathrm{b}$ & $1,38 \pm 0,06(20) \mathrm{a}$ & $1,00 \pm 0,08(21) \mathrm{b}$ & $0,24 \pm 0,05(20) \mathrm{c}$ \\
$\mathrm{MSA}+\mathrm{MSR}(\mathrm{g})$ & $2,34 \pm 0,12(22) \mathrm{a}$ & $2,72 \pm 0,09(20) \mathrm{a}$ & $2,36 \pm 0,18(21) \mathrm{a}$ & $0,49 \pm 0,08(20) \mathrm{b}$ \\
$\mathrm{P}\left(\mathrm{g} \mathrm{Kg}^{-1}\right)$ & $1,34 \pm 0,03(22) \mathrm{c}$ & $2,75 \pm 0,12(20) \mathrm{a}$ & $1,17 \pm 0,04(23) \mathrm{c}$ & $1,89 \pm 0,09(9) \mathrm{b}$ \\
$\mathrm{Ptot}(\mathrm{mg})$ & $1,06 \pm 0,08(22) \mathrm{b}$ & $2,10 \pm 0,14(20) \mathrm{a}$ & $0,90 \pm 0,07(23) \mathrm{b}$ & $0,84 \pm 0,18(9) \mathrm{b}$ \\
$\mathrm{COL}^{1}(\%)$ & $1,21 \pm 0,38(8) \mathrm{c}$ & $98,33 \pm 0,59(6) \mathrm{a}$ & $1,83 \pm 0,35(8) \mathrm{c}$ & $76,48 \pm 6,07(7) \mathrm{b}$ \\
$\mathrm{SEV}^{2}$ & $0,22 \pm 0,11(22) \mathrm{b}$ & $0,62 \pm 0,19(20) \mathrm{b}$ & $0,42 \pm 0,11(21) \mathrm{b}$ & $2,08 \pm 0,32(20) \mathrm{a}$
\end{tabular}

Nas linhas, médias seguidas das mesmas letras não diferem $(\mathrm{P} \leq 0,05)$ pelo teste de Student-Newman-Keuls. Apresentação: média \pm erro padrão (número de repetições)

${ }^{1}$ dados foram transformados para arcoseno $\sqrt{x}_{\mathrm{x}} / 100$ para análise

2 dados foram transformados para $\sqrt{ } \mathrm{x}+0,5$ para análise. Utilizou-se uma escala de notas de 0 a $5(0=$ sem sintomas e $5=$ podridão total de raízes) para avaliação visual da severidade da doença 


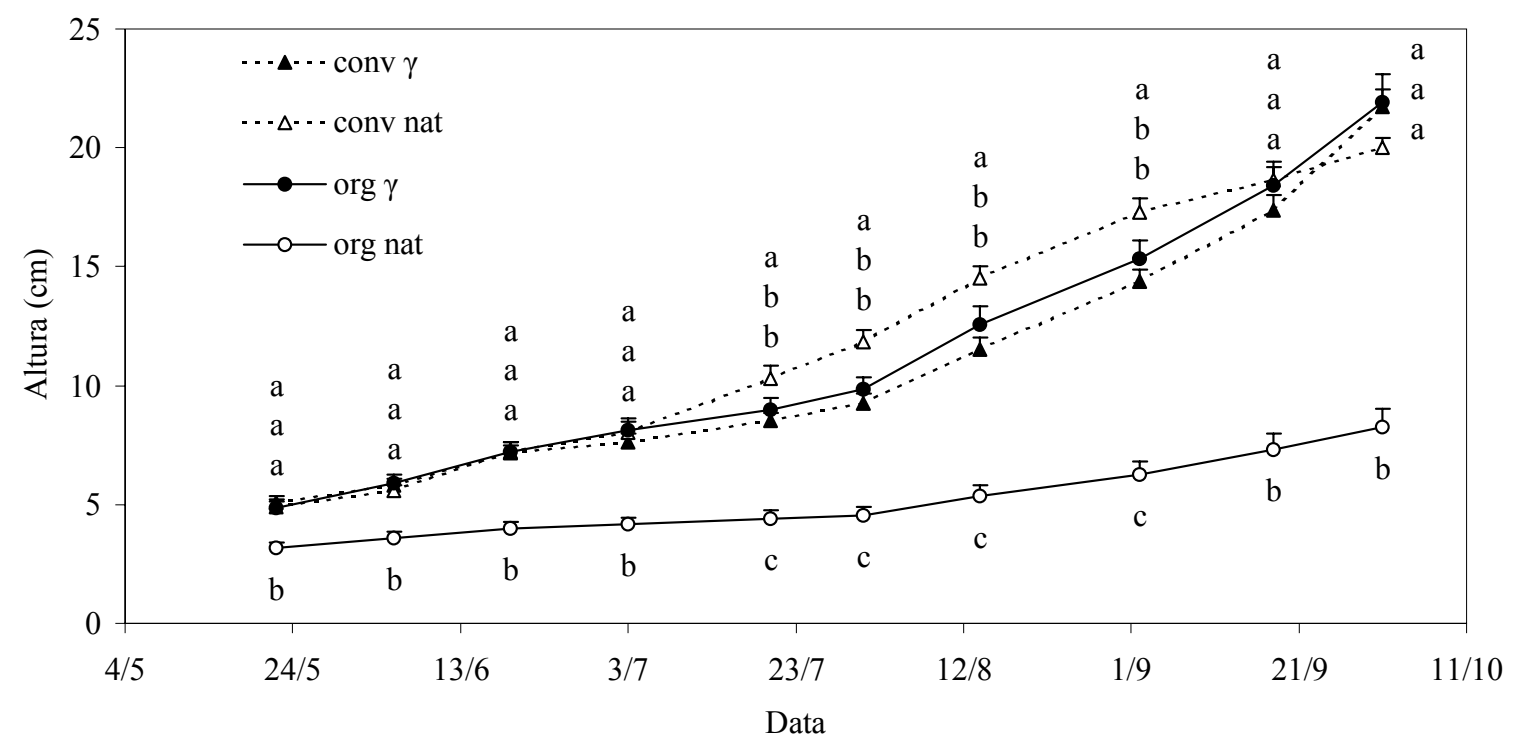

Figura 2 - Altura de planta, quinzenalmente, a partir de 22 de maio até 1 de outubro de 2002. Os tratamentos correspondem a solo irradiado $(\gamma)$ e natural (nat) dos sistemas de produção convencional (conv) e orgânico (org). Médias seguidas das mesmas letras, em cada data, não diferem entre si $(\mathrm{P} \leq 0,05)$ pelo teste de Student-Newman-Keuls

Tabela 4. Relação entre a massa da matéria seca de raiz e a de parte aérea (MSR/MSA) de plantas de limão 'Cravo' de seis meses e meio de idade, sob dois tratamentos de solo (radiação $\gamma$ e natural)

\begin{tabular}{lc}
\hline Tratamento de solo & MSR/MSA \\
\hline Radiação $\gamma$ & $0,76 \pm 0,01(43)$ \\
Natural & $1,01 \pm 0,03(40) *$
\end{tabular}

(*) indica que há diferença entre médias $(\mathrm{P} \leq 0,05)$ pelo teste $\mathrm{F}$ 


\subsection{Discussão}

Em outros momentos desse estudo, foi possível recuperar, do solo natural originário tanto do sistema convencional como do orgânico, Phytophthora e Pythium pelo método de iscas (Grimm \& Alexander, 1973), feitas de folhas de limão 'Cravo'. Portanto, a podridão de raízes observada nos tratamentos com solo natural, mesmo sem a infestação posterior de $P$. parasitica, pode ter sido causada por esses patógenos provenientes do campo, ou por outros não avaliados (Feichtenberger, 2001). Apesar de as coletas de solo nos cultivos terem sido realizadas ao redor de árvores aparentemente sadias, pelo menos sem sintomas de ataque de Phytophthora (gomose), era esperada a presença desse patógeno no solo devido à sua grande ocorrência nos pomares de plantas cítricas em São Paulo (Feichtenberger, 2001). A aplicação do filtrado permitiu que os microrganismos do campo, inclusive os patógenos, colonizassem os solos irradiados, ocupando assim o vazio biológico que havia sido gerado. Como a infestação de $P$. parasitica não aumentou a severidade de podridão de raízes nem afetou o crescimento das plantas de limão 'Cravo' em nenhum dos tratamentos de solo desse experimento (Tabela 2), sugere-se que a microbiota proveniente do campo dos dois sistemas de manejo teve maior influência nos resultados obtidos que a infestação posterior do patógeno.

Exceto o potássio, os demais nutrientes que tiveram seus teores elevados após o tratamento com radiação $\gamma$ não se encontravam em quantidades deficientes no solo natural dos sistemas convencional e orgânico (Tabela 1). Portanto, propõe-se que fatores biológicos foram os principais responsáveis pelas diferenças de comportamento das plantas entre solo natural e irradiado em cada sistema de produção. Os resultados indicaram que a comunidade de FMAs nativos do sistema convencional contribuiu para o maior crescimento das plantas durante os meses de julho e agosto (Figura 2). No sistema orgânico, apesar de as plantas terem apresentado colonização micorrízica elevada, a maior severidade da podridão de raízes (Tabela 3), provavelmente provocada por patógenos habitantes do solo, parece ter sido limitante para o seu crescimento. Surge então a pergunta: por que a podridão de raízes foi maior nas plantas de limão 'Cravo' cultivadas no solo natural do sistema orgânico que nas plantas do sistema convencional? 
Devido à importância de Phytophthora no apodrecimento das raízes de plantas cítricas (Whiteside et al., 1989) e sua provável participação nos danos observados, algumas considerações serão feitas com base nesse patógeno.

Doença é o resultado da interação patógeno, hospedeiro e ambiente. As populações de Phytophthora aumentam nos pomares durante os meses quentes e chuvosos (Feichtenberger, 2001). Na região do sudeste brasileiro, essas condições ocorrem na primavera-verão. A época de coleta dos solos utilizados nesse experimento (março) coincidiu com o final desse período favorável para a multiplicação do patógeno. Fatores específicos de manejo ou mesmo de implantação do pomar de cada propriedade promovem diferentes potenciais de inóculo. É possível que, no momento da coleta, o solo do sistema orgânico continha maior densidade de propágulos do patógeno que o solo do sistema convencional. Um aspecto que pode ter contribuído para isto é a própria densidade de raízes (Feichtenberger, 2001). Durante o peneiramento dos solos, foi observada visualmente uma maior quantidade de raízes nas amostras provenientes do manejo orgânico. Posteriormente, essa observação foi confirmada por medições de raízes em outra coleta (Capítulo 3). No entanto, o mesmo solo coletado em março, mantido na sombra a temperatura ambiente, e dois meses depois (maio) utilizado em outro experimento (experimento 3 do Capítulo 4), gerou resultados distintos. As plantas de limão 'Cravo' originárias de semeadura direta em solo natural do sistema orgânico não tiveram seu crescimento comprometido. Uma hipótese é que tenha ocorrido uma diminuição da densidade de inóculo durante o armazenamento do solo. Em geral, a competitividade de Phytophthora no solo, sem o hospedeiro vivo, é baixa (Whiteside et al., 1989), e também o antagonismo de outros microrganismos ocorre, principalmente em ambiente com alta atividade microbiana (Feichtenberger, 2001). Maior respiração basal e maior carbono da biomassa foram detectados no solo do sistema orgânico comparado ao convencional (Capítulo 3). A segunda hipótese para explicar as diferenças de crescimento das plantas entre os dois experimentos se baseia no fato de que a severidade de uma doença pode flutuar independentemente dos níveis de população do patógeno (Weste, 1983). Nesse caso, a disposição do hospedeiro em desenvolver a doença prevalece. As temperaturas médias mínimas e máximas dentro da casa de 
vegetação durante março e abril foram de aproximadamente $25{ }^{\circ} \mathrm{C}$ e $40{ }^{\circ} \mathrm{C}$ (Figura 1 ). As plantas cítricas são sensíveis às temperaturas extremas, e $25{ }^{\circ} \mathrm{C}$ a $30{ }^{\circ} \mathrm{C}$ corresponde à faixa ótima para a fotossíntese. A partir de cerca de $35{ }^{\circ} \mathrm{C}$, a fotossíntese é reduzida significativamente e o crescimento radicular afetado (Spiegel-Roy \& Goldschmidt, 1996). Essas condições de estresse podem ter predisposto as plantas durante esses meses, permitindo que o patógeno se desenvolvesse mais facilmente nesse ambiente. Em maio e junho, as temperaturas máximas e mínimas médias estiveram adequadas, próximas a $30{ }^{\circ} \mathrm{C}$ e $20{ }^{\circ} \mathrm{C}$ (Figura 2). Exatamente nessa época do ano, os viveiristas de plantas cítricas fazem as sementeiras de porta-enxertos (Teófilo Sobrinho, 1980). Portanto, sugere-se que as plantas do experimento de maio puderam reagir melhor ao ataque de Phytophthora, mesmo em temperaturas também favoráveis ao próprio desenvolvimento do patógeno. Outra evidência que confirma a importância da condição da planta para o desenvolvimento da doença é o aumento de perdas de plantas transplantadas com raiz nua. Além do estresse que sofre a planta, raízes se rompem abrindo portas de entrada para o patógeno (Feichtenberger, 2001). Independente da época de coleta do solo, em outros experimentos em que foram realizados transplantes aos vasos, o número de plantas mortas por apodrecimento radicular foi elevado (Capítulo 4). Em conclusão, propõe-se que a combinação de alta densidade de propágulos do patógeno e predisposição das plantas foi, provavelmente, a responsável pelo desempenho insatisfatório das plantas no solo natural do sistema orgânico.

Após a fase inicial de colonização dos FMAs, os benefícios da associação apareceram nas plantas do solo natural do sistema convencional. No final do experimento, mesmo com a mudança na taxa de crescimento no mês de setembro no solo natural, ainda foi detectada uma pequena resposta micorrízica positiva $(0,16)$ devido a um aumento na produção de biomassa radicular, observada pela maior relação raiz/parte aérea das plantas micorrizadas (Tabela 4). Possivelmente, a última fase de crescimento lento foi devido ao esgotamento de algum nutriente importante do solo (Barceló et al., 1992). O nitrogênio e, ou, o potássio, que já estavam muito baixos no solo (Tabela1), podem ter sido consumidos de forma mais rápida pelas plantas no solo natural convencional que pelas plantas no solo irradiado. 
A relação raiz/parte aérea varia com a espécie e a fase de crescimento da planta e com as condições ambientais (Klepper, 1991). A disponibilidade de nutrientes minerais, principalmente nitrogênio e fósforo, pode provocar alterações no crescimento e morfologia da raiz e na distribuição do sistema radicular no substrato. O crescimento da raiz aumenta nos locais com maior disponibilidade desses nutrientes comparado a sítios com menor disponibilidade, e leva ao decréscimo da relação da massa da matéria seca de raiz/ parte aérea (Marschner, 1995). A colonização micorrízica tem mostrado esse mesmo efeito sobre a relação raiz/parte aérea quando comparadas plantas micorrizadas com não micorrizadas (Marschner, 1995). No entanto, as plantas de limão 'Cravo' colonizadas por FMAs nativos dos dois sistemas de produção apresentaram maior relação de massa da matéria seca de raiz/parte aérea (Tabela 4). Talvez essa tendência descrita por Marschner tenha sido observada em plantas anuais. Logo depois da emergência das plantas anuais, a relação raiz/parte aérea é mais alta que nas fases posteriores de desenvolvimento, pois a parte aérea vai sendo favorecida. Em plantas perenes adultas essa relação é mais difícil de ser avaliada. Porém, em geral, fazendo comparações nos primeiros meses de idade, as plantas perenes possuem maior relação de massa da matéria seca do sistema radicular/parte aérea que as plantas anuais (Klepper, 1991). Esses e outros fatores, como hormônios (Spiegel-Roy \& Goldschmidt, 1996), competição por compostos fotossintetizados (Graham \& Eissenstat, 1994) e diferenças entre isolados de fungos micorrízicos (Fidelibus et al., 2001) influenciam a resposta da planta à simbiose e podem modificar a relação raiz/parte aérea. As plantas de limão 'Cravo' cultivadas no solo orgânico, mesmo afetadas no seu crescimento, mantiveram a relação raiz/parte aérea igual a das plantas no solo natural convencional (Tabelas 3 e 4). Sugere-se que os FMAs de ambos os sistemas de produção que estavam colonizando as plantas durante esse experimento são espécies promotoras do crescimento de raízes, como observado por Fidelibus et al. (2001), em limão 'Volkameriano'.

Apesar de a técnica de microcosmo não reproduzir as condições de campo, ela permitiu trabalhar com situações um pouco mais complexas que aquelas nas quais todos os fatores são isolados e controlados. O crescimento das plantas cultivadas nos solos naturais dos sistemas de produção com diferentes manejos chamou a atenção para vários 
aspectos relacionados com a interação dos FMAs nativos e patógenos de raiz, anteriormente discutidos. Esse tipo de abordagem foi interessante para levantar questões que devem ser aprofundadas em futuros estudos.

\subsection{Conclusões}

Ambos os sistemas de produção apresentaram comunidades de FMAs que desenvolveram elevada colonização radicular das plantas de limão 'Cravo' nos microcosmos. No entanto, a simbiose micorrízica não protegeu as plantas contra patógenos causadores de podridão de raízes nos microcosmos do sistema orgânico. 


\section{ATIVIDADE DE QUITINASE EM RAÍZES DE CITROS ASSOCIADAS A FUNGOS MICORRÍZICOS ARBUSCULARES NATIVOS}

\section{Resumo}

Existem evidências de que as quitinases são proteínas de defesa das plantas. Interações patogênicas e outros fatores bióticos e abióticos podem induzir essas proteínas nas plantas Fungos micorrízicos arbusculares (FMAs) podem modificar a expressão de quitinase, e essas reações de defesa podem contribuir para a proteção contra patógenos de raiz. Os objetivos deste estudo foram avaliar a capacidade indutora de resistência sistêmica da comunidade de FMAs de dois sistemas de produção de plantas cítricas (convencional e orgânico) a Phytophthora parasitica, bem como a atividade de quitinase, no sistema radicular de plantas de limão 'Cravo' sem e com micorriza. Em casa de vegetação, foi realizado um experimento com raízes divididas. Os FMAs dos solos dos sistemas de produção convencional e orgânico promoveram diferentes respostas de crescimento local e sistêmico das raízes das plantas micorrizadas. A associação micorrízica aumentou localmente o conteúdo de proteína nas raízes das plantas, mas não houve efeito sistêmico. Não foi possível avaliar a capacidade indutora de resistência dos fungos micorrízicos arbusculares nativos porque não houve desenvolvimento da podridão de raízes nas plantas de limão 'Cravo' após a infestação com P. parasitica, porém observou-se interação de patógenos de raiz do solo natural e os FMAs nativos. A atividade de quitinase foi igual nas raízes de plantas micorrizadas e não micorrrizadas cultivadas em solos dos sistemas de produção convencional e orgânico. 


\section{CHITINASE ACTIVITY IN CITRUS ROOTS ASSOCIATED WITH INDIGENOUS ARBUSCULAR MYCORRHIZAL FUNGI}

\section{Summary}

There are evidences that chitinases are plant defence proteins. Pathogenic interactions and other biotic and abiotic factors may induce these proteins in plants. Arbuscular mycorrhizal fungi (AMF) may modify the expression of chitinase, and these defence reactions may contribute to protect plants against root pathogens. The objectives of this study were to evaluate the capacity of the AMF community of two citrus systems (conventional and organic farming) to induce resistance against Phytophthora parasitica and the chitinase activity in 'Rangpur' lime roots with and without mycorrhiza. In greenhouse, an experiment with a split root system was carried out. The AMF of the conventional and organic farming promoted different local and systemic root growth responses in mycorrhizal plants. Mycorrhizal symbiosis increased protein content in plant roots, but the effect was only local, not systemic. It was not possible to evaluate the capacity of the indigenous AMF to induce resistance because the inoculation with $P$. parasitica did not develop the disease in 'Rangpur' lime roots. However, we observed interaction between root pathogens in natural soil and the indigenous AMF. Chitinase activity was not different in mycorrhizal and non mycorrhizal roots of plants grown in conventional and organic farming soils.

\subsection{Introdução}

Quitinases são proteínas presentes numa grande variedade de plantas. Apesar de desconhecida sua função fisiológica, existem evidências de que são proteínas de defesa com atividade anti-fúngica. Muitas quitinases já foram descritas como proteínas relacionadas com a patogênese (proteínas "PR", do inglês) (Graham \& Sticklen, 1994; 
van Loon \& van Strien, 1999). No entanto, não apenas interações patogênicas, mas outros fatores bióticos e abióticos induzem essas proteínas nas plantas (van Loon, 1985). Fungos micorrízicos arbusculares (FMAs) podem modificar a expressão de várias proteínas PRs nas raízes das plantas em simbiose, inclusive de quitinase, e essas reações de defesa podem contribuir para a proteção contra patógenos de raiz (Dumas-Gaudot et al., 1996, Gianinazzi-Pearson \& Gianinazzi, 2000).

Em tomate, o fungo micorrízico Glomus mosseae tem demonstrado reduzir a podridão de raízes causada por Phytophthora parasitica (Trotta et al., 1996; Cordier et al., 1996, Pozo et al, 1996; Cordier et al, 1998; Fusconi et al., 1999). Nessa interação, foi comprovado o envolvimento da indução de resistência (Cordier et al, 1998), um dos mecanismos de controle biológico propostos para explicar a proteção conferida pela simbiose micorrízica (Azcón-Aguilar \& Barea, 1996). Posteriormente, análises bioquímicas mostraram a indução local de uma isoforma ácida de quitinase nas raízes micorrizadas. Nas raízes infectadas pelo patógeno, tanto micorrizadas como não micorrizadas, ocorreu a indução de outra isoforma ácida, além de aumento na expressão de isoformas constitutivas (Pozo et al., 1996; Pozo et al., 2002).

Plantas cítricas micorrizadas podem apresentar menor severidade de podridão de raízes causada por P. parasitica (Davis \& Menge, 1980; 1981; Agnani, 2002). No entanto, pouco se conhece sobre a atividade de quitinase nas raízes de citros em resposta a interações mutualistas e patogênicas. Aumento da atividade de quitinase já foi detectado em raízes de oito porta-enxertos de citros em resposta à alimentação de larvas de um inseto praga (Mayer et al., 1995).

O presente estudo teve como objetivos avaliar a capacidade indutora de resistência sistêmica da comunidade de FMAs de dois sistemas de produção de plantas cítricas a $P$. parasitica, bem como a atividade de quitinase, no sistema radicular de plantas de limão 'Cravo' sem e com micorrizas. 


\subsection{Material e Métodos}

\section{Solo e comunidade de FMAs nativos}

Aos $45 \mathrm{Km}$ de Piracicaba na estrada para Anhembi, SP, duas propriedades produtoras de plantas cítricas vizinhas foram selecionadas. Ambas possuem lotes de laranja 'Pêra' enxertada em limão 'Cravo', de aproximadamente 12 anos de idade. Apesar do mesmo tipo de solo (Neossolo Quatzarênico), uma segue o manejo convencional e a outra o manejo orgânico. Cada propriedade possui uma comunidade distinta de FMAs (Capítulo 3).

Em julho de 2002, de cada sistema de produção, foi coletado solo de quatro pontos por árvore, num total de 15 árvores. Posteriormente, o solo foi misturado, peneirado $(2 \mathrm{~mm})$ e separado em duas partes. Uma foi enviada para desinfestação com radiação $\gamma(6 \mathrm{KGy})$ e outra permaneceu na sua condição original, ou seja, com a comunidade de FMAs nativos. Análise de fertilidade do solo foi realizada pelo Laboratório de Análise de Solo e Planta do IAC, Campinas (Tabela 1).

Tabela 1. Análise de fertilidade de solo dos sistemas de produção orgânico e convencional de plantas cítricas, em sua condição natural e após irradiação

\begin{tabular}{|c|c|c|c|c|c|c|}
\hline \multicolumn{3}{|c|}{ Determinações } & \multicolumn{4}{|c|}{ Sistemas de produção } \\
\hline \multirow{2}{*}{ Sigla } & \multirow[t]{2}{*}{ Descrição } & \multirow{2}{*}{ Unidade } & \multicolumn{2}{|c|}{ Orgânico } & \multicolumn{2}{|c|}{ Convencional } \\
\hline & & & Natural & Irradiado & Natural & Irradiado \\
\hline M.O. & Matéria Orgânica & $\mathrm{g} \mathrm{m}^{-3}$ & 13 & 16 & 13 & 11 \\
\hline pH & Solução $\mathrm{CaCl}_{2}$ & & 6,0 & 6,4 & 5,6 & 5,8 \\
\hline $\mathbf{P}$ & Fósforo Resina & $\mathrm{mg} \mathrm{dm}{ }^{-3}$ & 39 & 44 & 32 & 31 \\
\hline $\mathbf{K}$ & Potássio & $\mathrm{mmol}_{\mathrm{c}} \mathrm{dm}^{-3}$ & 0,3 & 0,4 & 0,9 & 0,8 \\
\hline Ca & Cálcio & $\mathrm{mmol}_{\mathrm{c}} \mathrm{dm}^{-3}$ & 52 & 78 & 28 & 26 \\
\hline Mg & Magnésio & $\mathrm{mmol}_{\mathrm{c}} \mathrm{dm}^{-3}$ & 29 & 48 & 16 & 16 \\
\hline $\mathbf{H}+\mathbf{A l}$ & Ac. Potencial & $\mathrm{mmol}_{\mathrm{c}} \mathrm{dm}^{-3}$ & 10 & 10 & 16 & 15 \\
\hline S.B. & Soma de Bases & $\mathrm{mmol}_{\mathrm{c}} \mathrm{dm}^{-3}$ & 81,3 & 126,4 & 44,9 & 42,8 \\
\hline CTC & Cap. Troca Catiônica & $\mathrm{mmol}_{\mathrm{c}} \mathrm{dm}^{-3}$ & 91,0 & 136,1 & 61,3 & 57,6 \\
\hline $\mathbf{V}$ & Saturação de Bases & $\%$ & 89 & 93 & 73 & 74 \\
\hline B & Boro & $\mathrm{mg} \mathrm{dm}^{-3}$ & 0,14 & 0,15 & 0,19 & 0,17 \\
\hline $\mathbf{C u}$ & Cobre & $\mathrm{mg} \mathrm{dm}$ & 2,5 & 2,6 & 6,3 & 5,9 \\
\hline $\mathbf{F e}$ & Ferro & $\mathrm{mg} \mathrm{dm}^{-3}$ & 19 & 12 & 39 & 35 \\
\hline Mn & Manganês & $\mathrm{mg} \mathrm{dm}$ & 5,4 & 5,7 & 2,9 & 2,5 \\
\hline Zn & Zinco & $\mathrm{mg} \mathrm{dm}^{-3}$ & 5,9 & 6,1 & 2,2 & 2,0 \\
\hline
\end{tabular}

Métodos de extração: P - resina; B - água quente; $\mathrm{Cu}, \mathrm{Fe}, \mathrm{Mn}, \mathrm{Zn}$ - DTPA 


\section{Inóculo de $\boldsymbol{P}$. parasitica}

O isolado de P. parasitica foi cedido pela Clínica Fitopatológica do Centro APTA Citros Sylvio Moreira, Cordeirópolis, SP. Foi preservado a temperatura ambiente em água destilada (método de Castellani) e por repicagens periódicas em meio de cultura. O meio de cultura recomendado por May \& Kimati (1997) foi utilizado tanto para a preservação como para o crescimento e esporulação do patógeno: $50 \mathrm{~g}$ de cenoura, $10 \mathrm{~g}$ de dextrose e $20 \mathrm{~g}$ de agar para $1 \mathrm{~L}$ de meio. Cenoura crua foi batida no liquidificador antes de ser adicionada ao meio.

Para a infestação do solo com $P$. parasitica, foi realizado o procedimento descrito em Araújo (1998), com algumas modificações. Discos de $7 \mathrm{~mm}$ de diâmetro foram retirados da borda de colônias de sete dias de idade crescidas no escuro a temperatura de $26-28{ }^{\circ} \mathrm{C}$ e passados para placas de Petri (Pyrex) esterilizadas. Cada placa recebeu 10 discos de micélio, $25 \mathrm{~mL}$ de água destilada esterilizada e 15 discos de 7 mm de diâmetro de folhas de limão 'Cravo'. Para que a produção de esporângios fosse estimulada nos discos de micélio e nas bordas das folhas, as placas foram mantidas em luz fluorescente contínua por uma semana, a temperaturas médias mínimas e máximas de 22 e $32{ }^{\circ} \mathrm{C}$, respectivamente. Paralelamente, 12 colônias de 15 dias de idade, crescidas em condições similares às já descritas, foram utilizadas para a preparação de 2 L de uma suspensão de hifas. No liquidificador, foi batido micélio raspado de 8 dessas colônias e 4 colônias inteiras, inclusive com meio. Em cada vaso correspondente a esse tratamento, com um bastão de vidro, 5 orifícios foram feitos no solo ao redor de cada planta, onde foram depositados dois discos de folha e três de micélio. Depois, $30 \mathrm{~mL}$ da suspensão de hifas foram aplicados. Nos demais vasos, também foram feitos os orifícios, porém os mesmos só receberam água. Durante os primeiros três dias depois da infestação, os vasos foram irrigados e água mantida nos pratos.

\section{Plantas de limão 'Cravo'}

Para obter plântulas de limão 'Cravo' com raízes divididas (raiz principal bifurcada) foi seguido o procedimento descrito por Davis \& Menge (1980). Em casa de vegetação, sementes de limão 'Cravo', previamente desinfestadas com hipoclorito de 
sódio $2,5 \%$ por $10 \mathrm{~min}$, foram germinadas em areia autoclavada. Depois de 45 dias da semeadura, a raiz principal das plantas foi podada $0,5 \mathrm{~cm}$ abaixo do colo. As plantas podadas foram plantadas novamente na areia e regadas com água fervida por mais 60 dias até a montagem dos experimentos. Foram selecionadas as plantas que desenvolveram raízes bifurcadas similares para a utilização nos experimentos.

\section{Experimento em casa de vegetação}

Para cada planta, um par de vasos plásticos de $500 \mathrm{~mL}$ foi utilizado. Primeiramente, foi colocada brita no fundo dos vasos, depois as plantas foram apoiadas com cada metade de sua raiz em um vaso e foram adicionados $350 \mathrm{~mL}$ de solo, irradiado ou natural, proveniente dos dois sistemas de produção, conforme a combinação dos tratamentos (Figura 1). Com a finalidade de evitar contaminação entre vasos, uma camada de $100 \mathrm{~mL}$ de areia foi colocada em cima do solo. O experimento foi repetido três vezes, com intervalo de um mês entre eles. Os transplantes foram realizados dias 29 de julho, 26 de agosto e 27 de setembro de 2002. Como no primeiro experimento várias plantas sofreram podridão nas raízes no solo natural e tiveram que ser substituídas depois do transplante, nos dois outros experimentos, $60 \mathrm{~mL}$ de solo irradiado foram colocados próximo às raízes nos vasos com solo natural, no momento do transplante, para diminuir esse problema. Para restabelecimento da microbiota nativa, exceto fungos micorrízicos, $50 \mathrm{~mL}$ de filtrado de solo do sistema convencional e orgânico foram aplicados nos vasos que receberam seus respectivos solos irradiados. Para preparação do filtrado, uma suspensão de $100 \mathrm{~mL}$ de solo natural em água esterilizada foi agitada manualmente, passada na peneira de $45 \mu \mathrm{m}$ e completada para 1,2 L de filtrado. Foi preparada uma solução estoque de $\mathrm{KNO}_{3} 1 \mathrm{M}$. Semanalmente, foram aplicados $25 \mathrm{~mL}$

por vaso da solução diluída ( $3 \mathrm{~mL}$ da solução estoque $\left.\mathrm{L}^{-1}\right)$. $\mathrm{O}$ desenho experimental foi em inteiramente casualisado, com 10 repetições. 
(1)

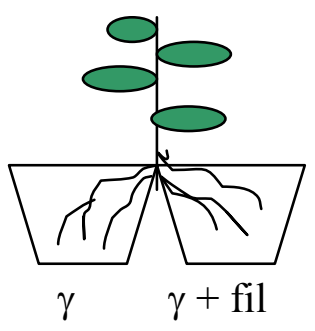

(A)
(B)
(2)

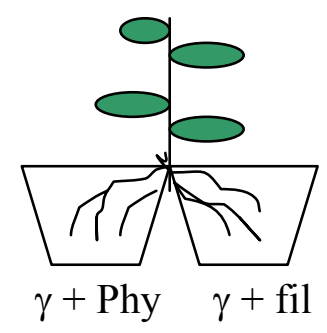

(A)
(3)

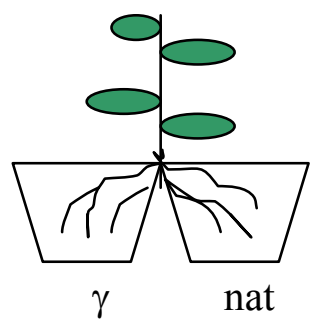

(A)

(B)
(4)

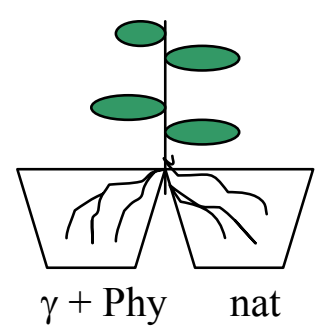

(A)

(B)

Figura 1 - Esquema dos tratamentos. As quatro combinações apresentadas foram usadas para solo do sistema de manejo convencional e orgânico: $(\gamma)$ solo irradiado; $(\gamma+$ fil $)$ solo irradiado que recebeu filtrado; $(\gamma+$ Phy $)$ solo irradiado infestado com P. parasitica; (nat) solo natural

Quatro meses depois do transplante, o solo foi infestado com $P$. parasitica. Durante todo o experimento, os vasos foram irrigados com água fervida. O primeiro experimento foi colhido cinco semanas depois da infestação com P. parasitica. $\mathrm{O}$ segundo experimento foi colhido em duas etapas: metade das repetições na primeira semana depois da infestação com $P$. parasitica e a outra metade, na quinta semana. $\mathrm{O}$ terceiro experimento também foi colhido em duas etapas, porém nas segunda e quinta semanas após a aplicação do patógeno. Todos experimentos utilizaram solo coletado em julho de 2002 e foram realizados em casa de vegetação, no Instituto Agronômico - IAC, Centro Experimental Central, Campinas. As médias das temperaturas mínimas e máximas diárias dentro da casa de vegetação durante esse período estão apresentadas na Figura 2. 


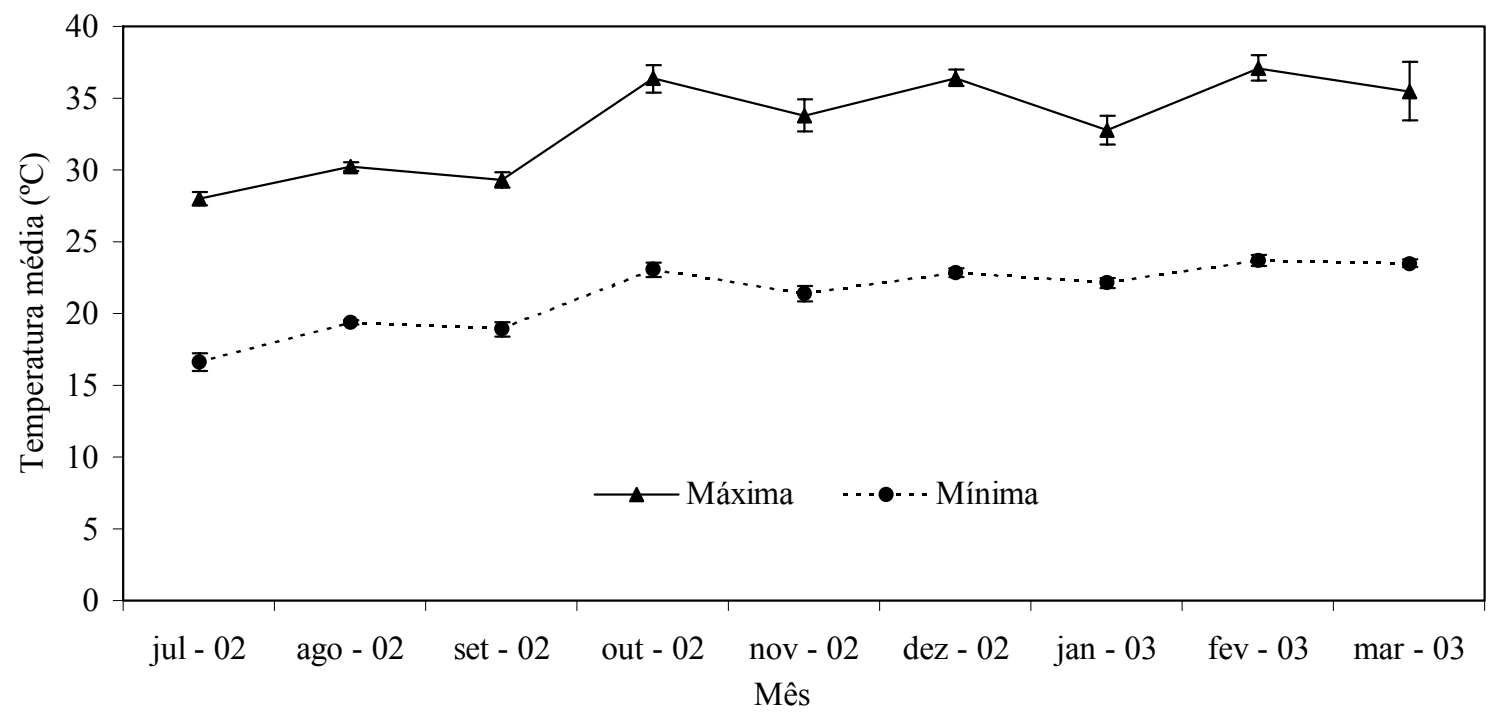

Figura 2 - Médias das temperaturas mínimas e máximas diárias de julho de 2002 a março de 2003 na casa de vegetação, Centro Experimental Central - IAC, Campinas, SP

\section{Variáveis avaliadas}

A massa da matéria fresca de raiz foi obtida no momento da colheita das plantas na quinta semana depois da infestação com $P$. parasitica. Uma parte da raiz foi guardada em álcool 50\% para posterior avaliação da colonização micorrízica e outra parte congelada em nitrogênio líquido e armazenada a $-80{ }^{\circ} \mathrm{C}$ para análise da atividade de quitinase.

As estruturas dos FMAs nas raízes foram coloridas com base no método desenvolvido por Vierheilig et al. (1998). As raízes guardadas em álcool foram lavadas em água corrente, clareadas em $\mathrm{KOH} 10 \%$ em banho maria fervendo por 15 min e novamente lavadas. Em seguida, colocadas em uma solução a 5\% de tinta de caneta (Parker, preta) e vinagre branco de cozinha puro (4\% de ácido acético), por 3-4 min em banho maria fervendo. Depois de lavados em água corrente, 30 segmentos de $1 \mathrm{~cm}$ de raiz colorida por planta foram montados em lâminas e observados em microscópio para a determinação da porcentagem de colonização micorrízica (Giovannetti \& Mosse, 1980). 
Para extração e quantificação de proteína, 1 g de raiz congelada de cada amostra foi macerado com nitrogênio líquido em almofariz de porcelana e recolhido em $4 \mathrm{~mL}$ de tampão de acetato de sódio $(0,1 \mathrm{M}, \mathrm{pH} 5,0)$. O homogeneizado foi centrifugado a 15000 $g$ por $20 \mathrm{~min}$ a $4^{\circ} \mathrm{C}$. O sobrenadante foi filtrado $(0,45 \mu \mathrm{m})$ com seringa e guardado em micro tubos a $-20{ }^{\circ} \mathrm{C}$ até a realização das análises. As análises foram determinadas colorimetricamente em leitor de microplacas (Microplate Reader - Benchmark; Bio-Rad - Programa Microplate Manager 5.0). Foi utilizado o método de Bradford (1976) para análise de proteína, usando o reagente comercial da Bio-Rad e albumina de soro bovino como padrão. A atividade de quitinase foi determinada como descrita em Stangarlin (1999): $200 \mu \mathrm{L}$ de amostra foram diluídas em $600 \mu \mathrm{L}$ de tampão de acetato de sódio $(0,1$ M, pH 5,0), onde foram adicionados $200 \mu \mathrm{L}$ do substrato CM- Chitin RBV (Loewe Biochemica). Após o procedimento de incubação $\left(30 \mathrm{~min}\right.$ a $40{ }^{\circ} \mathrm{C}$ em banho maria), parou-se a reação com $200 \mu \mathrm{L}$ de $\mathrm{HCl} 1 \mathrm{M}$, e centrifugou-se a $5000 \mathrm{~g}$ por 5 min a $4{ }^{\circ} \mathrm{C}$. Foram transferidos $200 \mu \mathrm{L}$ do sobrenadante para cada orifício da placa, com três repetições por amostra. A absorbância foi lida a $550 \mathrm{~nm}$. Foram realizadas análises de três amostras por tratamento na segunda colheita do experimento dois e na primeira colheita do experimento três.

A parte aérea das plantas colhidas na quinta semana depois da infestação com $P$. parasitica foi seca em estufa a $60{ }^{\circ} \mathrm{C}$ até peso constante. Depois de pesadas, as plantas foram moídas e enviadas ao Laboratório de Análise de Solo e Planta do IAC, Campinas, para a realização das análises de macro e micronutrientes.

\section{Análise estatística}

Foi utilizado um modelo misto linear, que considera efeitos aleatórios e fixos. Os experimentos foram considerados efeitos aleatórios. Os sistemas de produção e os tratamentos de solo foram considerados efeitos fixos. Foi aplicado o procedimento de estimação de REML (restricted max likelihood) do programa SAS. A análise foi realizada separadamente para as combinações 1 e 2,1 e 3, 3 e 4, e 2 e 4 dos tratamentos (Figura 1). Dessa forma, cada análise consistiu em um arranjo fatorial completo $2 \times 2$ (dois sistemas de produção e duas combinações de tratamentos de solo). 


\subsection{Resultados}

O método utilizado para a divisão de raízes das plantas de limão 'Cravo' foi adequado. Do total de plântulas que tiveram suas raízes podadas, aproximadamente $60 \%$ desenvolveram raízes bifurcadas similares e foram utilizadas nos experimentos. Depois de transplantadas com raízes divididas, as plantas se desenvolveram satisfatoriamente (Figura 3). A camada de areia colocada sobre o solo provavelmente contribuiu para a pouca contaminação entre vasos. As raízes A (Figura 1) das combinações de tratamentos de solo 3 e 4 dos sistemas convencional e orgânico apresentaram níveis de colonização micorrízica inferiores a 3\%, enquanto as raízes $\mathrm{B}$, níveis superiores a $90 \%$. Nas combinações de tratamentos do solo 1 e 2, as contaminações por FMAs atingiram no máximo $1 \%$ de colonização micorrízica.

As Tabelas 2 a 5 mostram os resultados das análises estatísticas das principais variáveis avaliadas. Os parâmetros de covariância dos experimentos foram sempre menores que os dos resíduos, indicando que maior variabilidade ocorreu entre as repetições dentro de cada experimento que entre experimentos. Portanto, o modelo misto pode ser utilizado na análise dos três experimentos em conjunto, incluindo experimento como um fator aleatório.

Como em nenhuma das variáveis avaliadas houve efeito significativo do tratamento de solo nas análises das combinações 1-2 e 3-4 (Tabelas 2 a 5), considera-se que não houve efeito da infestação de $P$. parasitica sobre as plantas.

Nas análises das combinações sem fungos micorrízicos (1-2), as massas da matéria fresca da raiz A e da raiz B foram maiores nas plantas cultivadas no solo do sistema orgânico. Os resultados se inverteram quando foram analisadas as combinações com fungos micorrízicos (3-4): as raízes se desenvolveram mais nas plantas cultivadas no solo do sistema convencional (Tabela 6; Figura 4). A maior diferença entre B e A observada no sistema orgânico nas combinações 1-2 indica que o filtrado do solo desse sistema estimulou localmente o desenvolvimento das raízes (raiz B) mais que o filtrado do solo do sistema convencional. Já nas combinações 3-4, a maior diferença entre B e A no sistema convencional mostra que a comunidade de FMAs nativos desse sistema teve 
maior efeito local sobre as raízes colonizadas (raiz B) que a comunidade do sistema orgânico (Tabela 6).

Houve efeito da interação de sistema de produção e tratamento de solo sobre a massa da matéria fresca de raiz nas análises das combinações 1-3 e 2-4 (Tabela 2). Ambas as análises mostraram valores e tendências similares (Figura 5), o que confirma que a infestação com $P$. parasitica não teve efeito sobre as raízes. Por um lado, a comunidade de FMAs nativa do sistema de produção convencional provocou resposta positiva na massa das raízes, tanto sistêmica (Figura 5a; 5d) como local (Figura 5b; 5e), sendo o efeito local mais pronunciado que o sistêmico (Figura 5c; 5f). Por outro lado, a comunidade do sistema orgânico produziu pequeno aumento na massa de raízes de forma local (Figura 5b; 5e) e sistêmica (Figura 5a; 5d) e o efeito local foi, proporcionalmente, menor que o sistêmico (Figura 5c; 5f). 
(A)

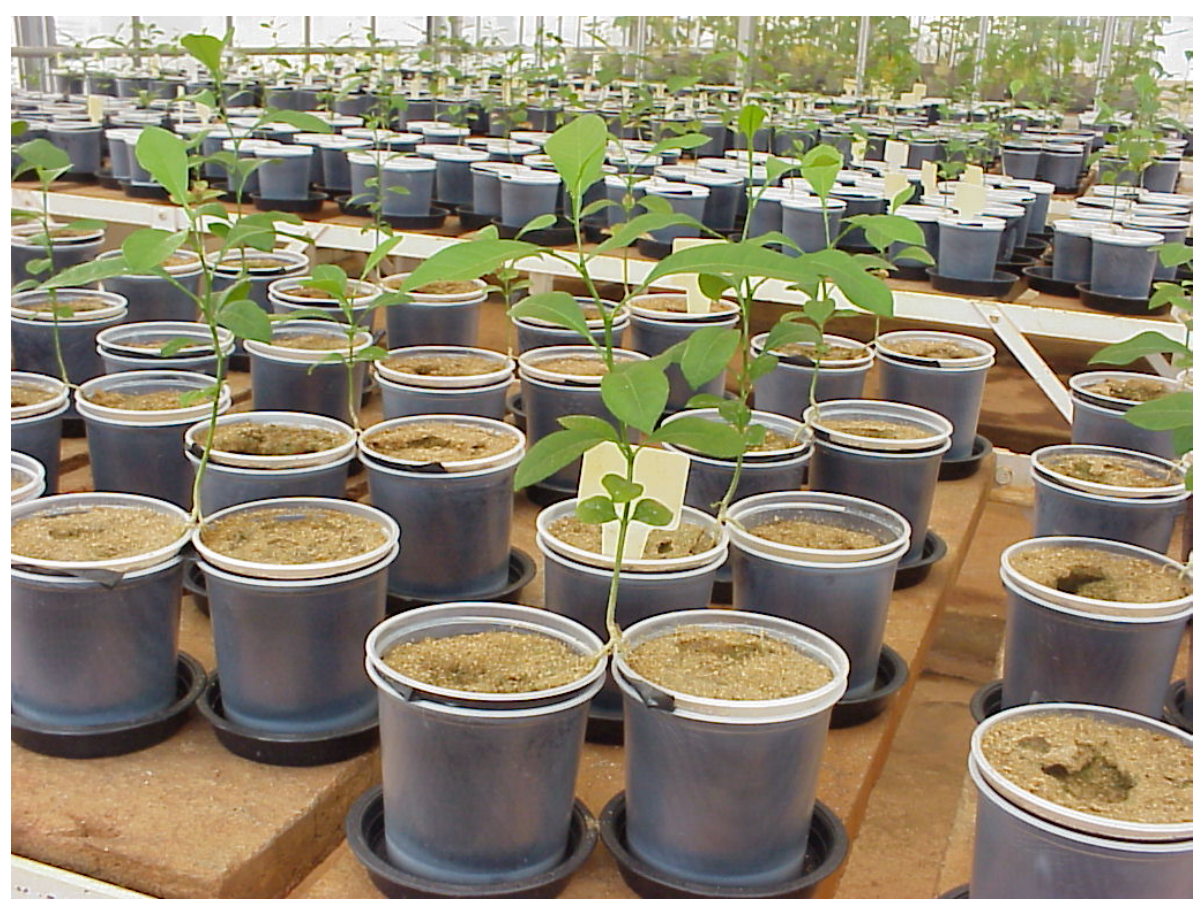

(B)

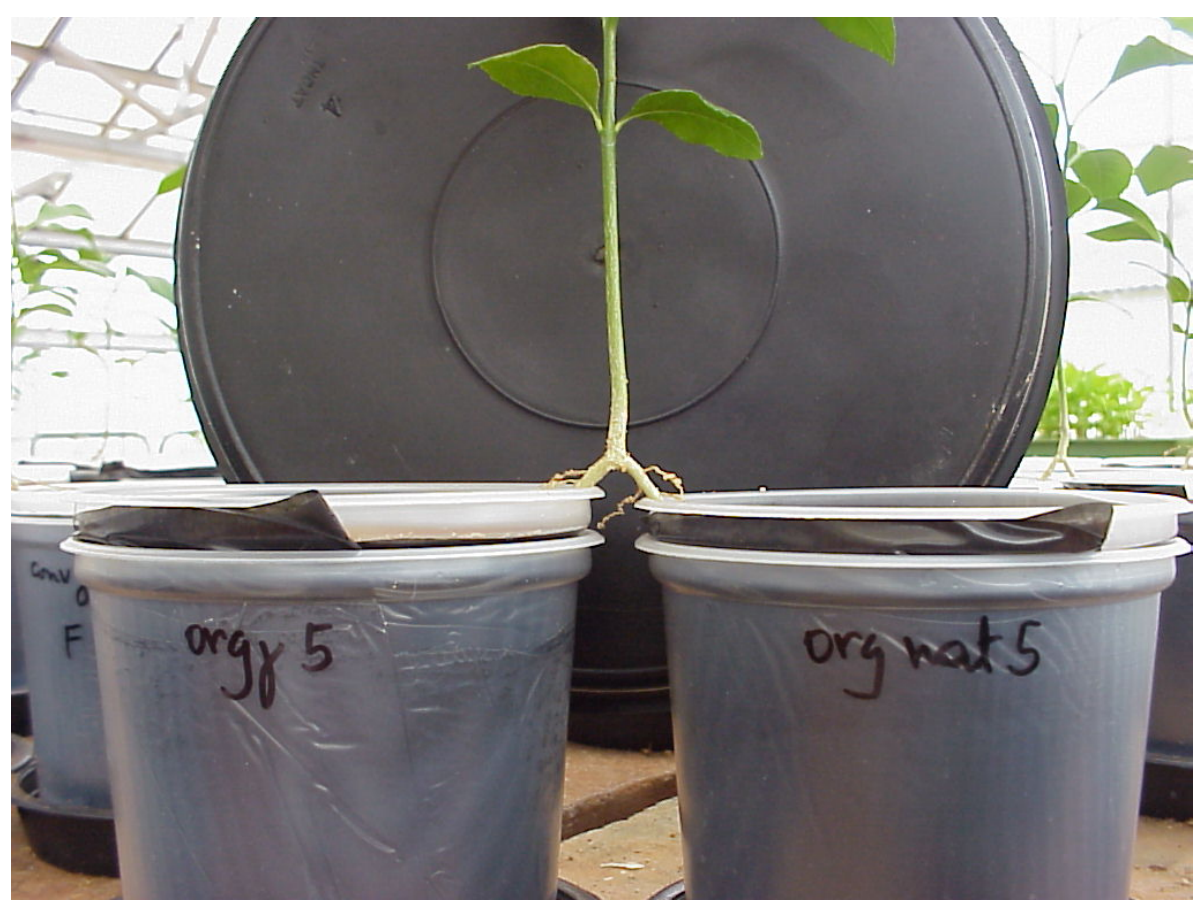

Figura 3 - Plantas de limão 'Cravo' com raízes divididas, três meses depois do transplante. (A) Vista geral dos experimentos; (B) detalhe da divisão de raízes 
Tabela 2. Parâmetros de covariância dos efeitos aleatórios e teste $\mathrm{F}$ da análise de variância dos efeitos fixos na massa da matéria fresca da raiz A, da raiz B e da diferença entre raiz B e A de plantas de limão 'Cravo', considerando separadamente as combinações de tratamentos 1-2, 1-3, 3-4, e 2-4. Os efeitos fixos são sistemas de produção (convencional e orgânico) e tratamentos de solo (radiação $\gamma$ com e sem $P$. parasitica, radiação $\gamma$ com filtrado e natural). As combinações de tratamentos são: 1 (raiz A: radiação $\gamma$; raiz B: radiação $\gamma$ com filtrado), 2 (raiz A: radiação $\gamma$ com P. parasitica; raiz B: radiação $\gamma$ com filtrado), 3 (raiz A: radiação $\gamma$; raiz B: natural), 4 (raiz A: radiação $\gamma$ com P. parasitica; raiz B: natural)

\begin{tabular}{|c|c|c|c|c|c|c|c|c|c|c|c|c|}
\hline & \multicolumn{3}{|c|}{$1-2$} & \multicolumn{3}{|c|}{$1-3$} & \multicolumn{3}{|c|}{$3-4$} & \multicolumn{3}{|c|}{$2-4$} \\
\hline & A & $\mathrm{B}$ & $\mathrm{B}-\mathrm{A}$ & A & $\mathrm{B}$ & $\mathrm{B}-\mathrm{A}$ & A & $\mathrm{B}$ & $\mathrm{B}-\mathrm{A}$ & A & $\mathrm{B}$ & B-A \\
\hline \multicolumn{13}{|c|}{ Efeitos aleatórios } \\
\hline Experimento & 0,18 & 0,18 & 0 & 0,30 & 0,80 & 0,11 & 0,47 & 1,42 & 0,26 & 0,32 & 0,47 & 0,11 \\
\hline Resíduo & 0,39 & 0,39 & 0,25 & 0,43 & 1,20 & 0,60 & 0,51 & 1,87 & 0,89 & 0,45 & 1,05 & 0,55 \\
\hline \multicolumn{13}{|l|}{ Efeitos fixos } \\
\hline \multicolumn{13}{|l|}{$\begin{array}{l}\text { Sistema de } \\
\text { produção }\end{array}$} \\
\hline$(\mathrm{SP})$ & $*$ & $* * *$ & $*$ & $\mathrm{~ns}$ & ns & $\mathrm{ns}$ & $\mathrm{ns}$ & $* *$ & $* *$ & ns & ns & ns \\
\hline Tratamento & & & & & & & & & & & & \\
\hline de solo (TS) & ns & ns & ns & $* *$ & $* * *$ & $* *$ & ns & ns & ns & $*$ & $* * *$ & $* * *$ \\
\hline $\mathrm{SP} \times \mathrm{TS}$ & ns & ns & ns & $*$ & $* * *$ & $* *$ & ns & ns & ns & ns & $* *$ & $* * *$ \\
\hline
\end{tabular}

Níveis de significância, * $(\mathrm{P} \leq 0,05), * *(\mathrm{P} \leq 0,01), * * *(\mathrm{P} \leq 0,001)$ e não significativo (ns) 
Tabela 3. Parâmetros de covariância dos efeitos aleatórios e teste $\mathrm{F}$ da análise de variância dos efeitos fixos no teor de fósforo e na massa da matéria seca de parte aérea (MAS) de plantas de limão 'Cravo', considerando separadamente as combinações de tratamentos 1-2, 1-3, 3-4, e 2-4. Os efeitos fixos são sistemas de produção (convencional e orgânico) e tratamentos de solo (radiação $\gamma$ com e sem $P$. parasitica, radiação $\gamma$ com filtrado e natural). As combinações de tratamentos são: 1 (raiz A: radiação $\gamma$; raiz B: radiação $\gamma$ com filtrado), 2 (raiz A: radiação $\gamma$ com $P$. parasitica; raiz B: radiação $\gamma$ com filtrado), 3 (raiz A: radiação $\gamma$; raiz B: natural), 4 (raiz A: radiação $\gamma \operatorname{com} P$. parasitica; raiz B: natural)

\begin{tabular}{|c|c|c|c|c|}
\hline & $1-2$ & $1-3$ & $3-4$ & $2-4$ \\
\hline & \multicolumn{4}{|c|}{ MSA } \\
\hline \multicolumn{5}{|l|}{ Efeitos aleatórios } \\
\hline Experimento & 0,22 & 0,78 & 3,61 & 1,49 \\
\hline Resíduo & 0,80 & 2,98 & 3,77 & 1,99 \\
\hline \multicolumn{5}{|l|}{ Efeitos fixos } \\
\hline Sistema de produção (SP) & $* * *$ & ns & $*$ & ns \\
\hline Tratamento de solo (TS) & ns & $* * *$ & ns & $* * *$ \\
\hline SP $x$ TS & ns & * & ns & $* *$ \\
\hline & \multicolumn{4}{|c|}{ Fósforo } \\
\hline \multicolumn{5}{|l|}{ Efeitos aleatórios } \\
\hline Experimento & 0,009 & 0,019 & 0,026 & 0,008 \\
\hline Resíduo & 0,018 & 0,060 & 0,122 & 0,078 \\
\hline \multicolumn{5}{|l|}{ Efeitos fixos } \\
\hline Sistema de produção (SP) & $* * *$ & ns & $* *$ & ns \\
\hline Tratamento de solo (TS) & ns & $* * *$ & ns & $* * *$ \\
\hline $\mathrm{SP} \times \mathrm{TS}$ & $\mathrm{ns}$ & $* * *$ & ns & $* *$ \\
\hline
\end{tabular}

Níveis de significância, * $(\mathrm{P} \leq 0,05), * *(\mathrm{P} \leq 0,01), * * *(\mathrm{P} \leq 0,001)$ e não significativo (ns) 
Tabela 4. Parâmetros de covariância dos efeitos aleatórios e teste $\mathrm{F}$ da análise de variância dos efeitos fixos no conteúdo de proteína na raiz A, na raiz B e na diferença entre raiz B e A de plantas de limão 'Cravo', considerando separadamente as combinações de tratamentos 1-2, 1-3, 3-4, e 2-4. Os efeitos fixos são sistemas de produção (convencional e orgânico) e tratamentos de solo (radiação $\gamma$ com e sem $P$. parasitica, radiação $\gamma$ com filtrado e natural). As combinações de tratamentos são: 1 (raiz A: radiação $\gamma$; raiz B: radiação $\gamma$ com filtrado), 2 (raiz A: radiação $\gamma$ com $P$. parasitica; raiz B: radiação $\gamma$ com filtrado), 3 (raiz A: radiação $\gamma$; raiz B: natural), 4 (raiz A: radiação $\gamma$ com $P$. parasitica; raiz B: natural)

\begin{tabular}{|c|c|c|c|c|c|c|c|c|c|c|c|c|}
\hline & \multicolumn{3}{|c|}{$1-2$} & \multicolumn{3}{|c|}{$1-3$} & \multicolumn{3}{|c|}{$3-4$} & \multicolumn{3}{|c|}{$2-4$} \\
\hline & A & $\mathrm{B}$ & B-A & A & $\mathrm{B}$ & B-A & A & $\mathrm{B}$ & B-A & A & $\mathrm{B}$ & B-A \\
\hline \multicolumn{13}{|c|}{ Efeitos aleatórios } \\
\hline Experimento & 3356 & 2466 & 0 & 2381 & 3200 & 0 & 1319 & 4717 & 483 & 1997 & 3919 & 0 \\
\hline Resíduo & 3366 & 4655 & 3644 & 3619 & 4420 & 6042 & 2110 & 4887 & 6536 & 1910 & 5242 & 4474 \\
\hline \multicolumn{13}{|l|}{ Efeitos fixos } \\
\hline \multicolumn{13}{|l|}{$\begin{array}{l}\text { Sistema de } \\
\text { produção }\end{array}$} \\
\hline (SP) & ns & ns & ns & ns & ns & ns & ns & $*$ & ns & ns & ns & ns \\
\hline Tratamento & & & & & & & & & & & & \\
\hline de solo (TS) & $*$ & ns & ns & ns & $* *$ & $* *$ & ns & ns & ns & ns & $* * *$ & $* *$ \\
\hline $\mathrm{SP} \times \mathrm{TS}$ & ns & ns & ns & ns & ns & ns & ns & ns & ns & ns & ns & ns \\
\hline
\end{tabular}

Níveis de significância, * $(\mathrm{P} \leq 0,05), * *(\mathrm{P} \leq 0,01), * * *(\mathrm{P} \leq 0,001)$ e não significativo (ns) 
Tabela 5. Parâmetros de covariância dos efeitos aleatórios e teste $\mathrm{F}$ da análise de variância dos efeitos fixos na atividade de quitinase na raiz A, na raiz B e na diferença entre raiz B e A de plantas de limão 'Cravo', considerando separadamente as combinações de tratamentos 1-2, 1-3, 3-4, e 2-4. Os efeitos fixos são sistemas de produção (convencional e orgânico) e tratamentos de solo (radiação $\gamma$ com e sem $P$. parasitica, radiação $\gamma$ com filtrado e natural). As combinações de tratamentos são: 1 (raiz A: radiação $\gamma$; raiz B: radiação $\gamma$ com filtrado), 2 (raiz A: radiação $\gamma$ com $P$. parasitica; raiz B: radiação $\gamma$ com filtrado), 3 (raiz A: radiação $\gamma$; raiz B: natural), 4 (raiz A: radiação $\gamma$ com $P$. parasitica; raiz B: natural)

\begin{tabular}{|c|c|c|c|c|c|c|c|c|c|c|c|c|}
\hline & \multicolumn{3}{|c|}{$1-2$} & \multicolumn{3}{|c|}{$1-3$} & \multicolumn{3}{|c|}{$3-4$} & \multicolumn{3}{|c|}{$2-4$} \\
\hline & A & $\mathrm{B}$ & $\mathrm{B}-\mathrm{A}$ & A & B & $\mathrm{B}-\mathrm{A}$ & A & B & B-A & A & B & B-A \\
\hline \multicolumn{13}{|c|}{ Efeitos aleatórios } \\
\hline Experimento & 2841 & 1223 & 0 & 1429 & 1537 & 0 & 823 & 2572 & 133 & 1837 & 2274 & 0 \\
\hline Resíduo & 4338 & 4993 & 4755 & 3565 & 4440 & 5677 & 1317 & 3245 & 4210 & 2175 & 3755 & 3287 \\
\hline \multicolumn{13}{|l|}{ Efeitos fixos } \\
\hline \multicolumn{13}{|l|}{$\begin{array}{l}\text { Sistema de } \\
\text { produção }\end{array}$} \\
\hline (SP) & $\mathrm{ns}$ & $\mathrm{ns}$ & $\mathrm{ns}$ & $\mathrm{ns}$ & $\mathrm{ns}$ & ns & $*$ & $\mathrm{~ns}$ & ns & ns & $\mathrm{ns}$ & $\mathrm{ns}$ \\
\hline Tratamento & & & & & & & & & & & & \\
\hline de solo (TS) & ns & ns & ns & ns & ns & ns & ns & ns & ns & ns & ns & ns \\
\hline $\mathrm{SP} \times \mathrm{TS}$ & $\mathrm{ns}$ & $\mathrm{ns}$ & $\mathrm{ns}$ & $\mathrm{ns}$ & $\mathrm{ns}$ & ns & $\mathrm{ns}$ & $\mathrm{ns}$ & $\mathrm{ns}$ & ns & $\mathrm{ns}$ & $\mathrm{ns}$ \\
\hline
\end{tabular}

Os dados foram multiplicados por 1000 para realização das análises

Níveis de significância, * $(\mathrm{P} \leq 0,05), * *(\mathrm{P} \leq 0,01), * * *(\mathrm{P} \leq 0,001)$ e não significativo (ns) 
Tabela 6. Massa da matéria fresca de raiz (MFR) das raízes A e B de plantas de limão 'Cravo' e a diferença entre raiz B e A. Plantas cultivadas em solo dos sistemas convencional e orgânico, considerando as combinações de tratamentos de solo sem FMAs (1-2) e com a FMAs (3-4). As combinações de tratamentos são: 1 (raiz A: radiação $\gamma$; raiz B: radiação $\gamma$ com filtrado), 2 (raiz A: radiação $\gamma$ com P. parasitica; raiz B: radiação $\gamma$ com filtrado), 3 (raiz A: radiação $\gamma$; raiz B: natural), 4 (raiz A: radiação $\gamma$ com P. parasitica; raiz B: natural)

\begin{tabular}{ccccccc}
\hline & \multicolumn{7}{c}{ MFR (g) } \\
& A & $1-2$ & & $3-4$ & \\
& B & B-A & A & B & B-A \\
\hline Convencional & 1,22 & 1,19 & $-0,03$ & 2,01 & $3,18 *$ & $1,17 *$ \\
Orgânico & $1,47 *$ & $1,69 *$ & $0,22 *$ & 1,64 & 1,88 & 0,24 \\
\hline
\end{tabular}

Nas colunas, $\left(^{*}\right)$ indica que há diferença entre médias pelo teste $\mathrm{F}$ de análise de variância $(\mathrm{P} \leq 0,05)$

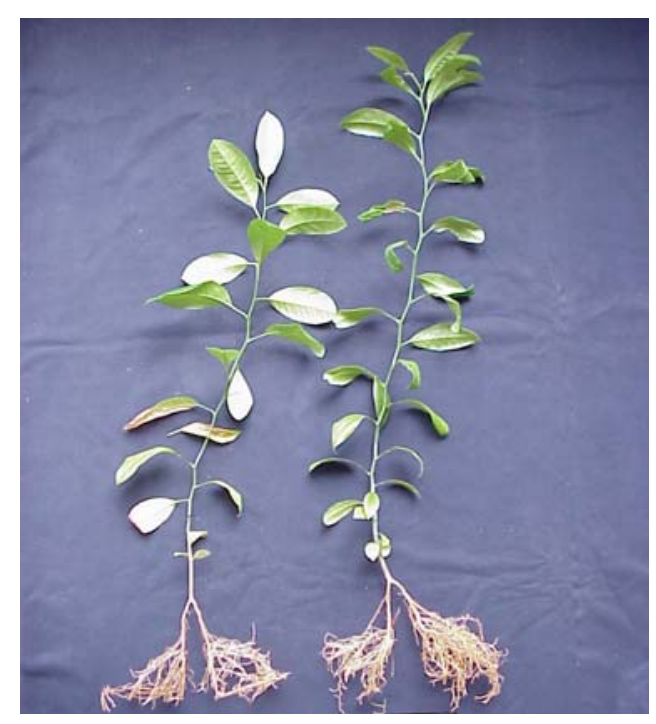

Figura 4 - Plantas de limão 'Cravo' com raízes divididas. Planta esquerda foi cultivada no solo do sistema orgânico e planta direita no solo do sistema convencional. Raiz esquerda (raiz A) de cada planta estava no vaso com solo irradiado (radiação $\gamma$ ) e raiz direita (raiz B) no vaso com solo natural (com a comunidade de FMAs nativos) 
(a) Raiz A

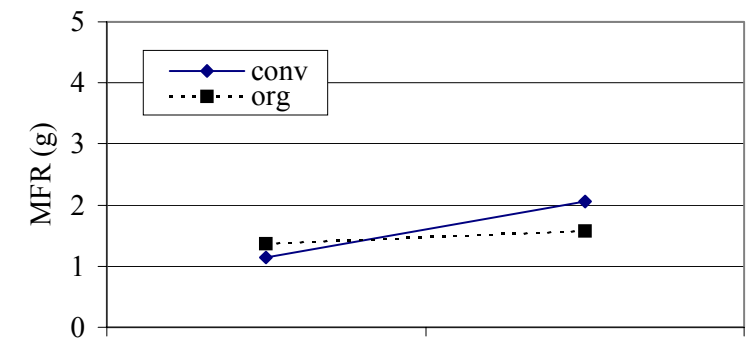

(b) Raiz B

1

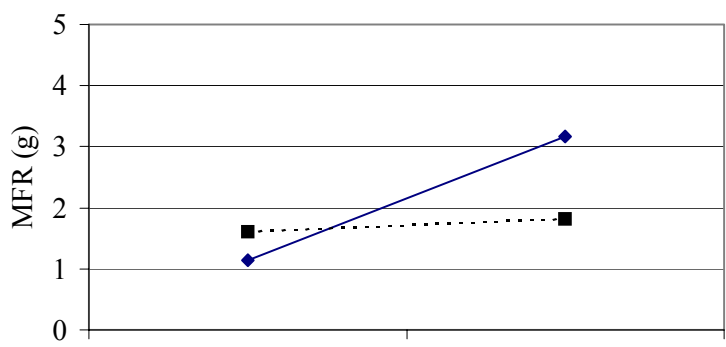

(c) $\mathrm{B}$ - $\mathrm{A}$

1

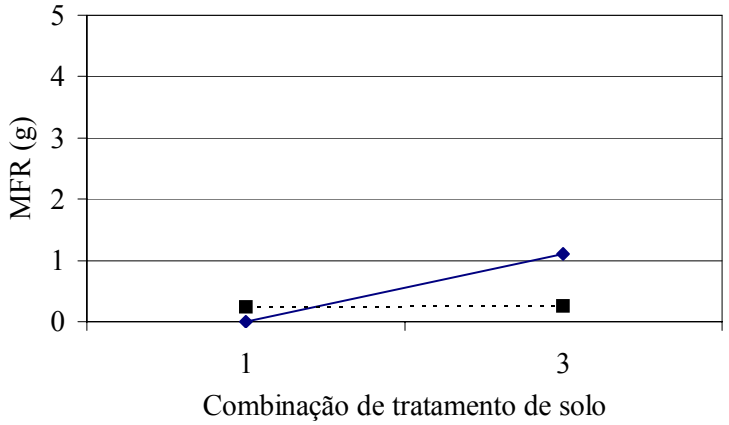

(d) Raiz A

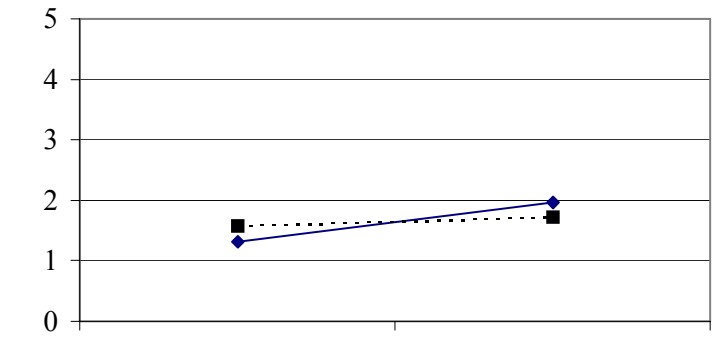

(e) Raiz B

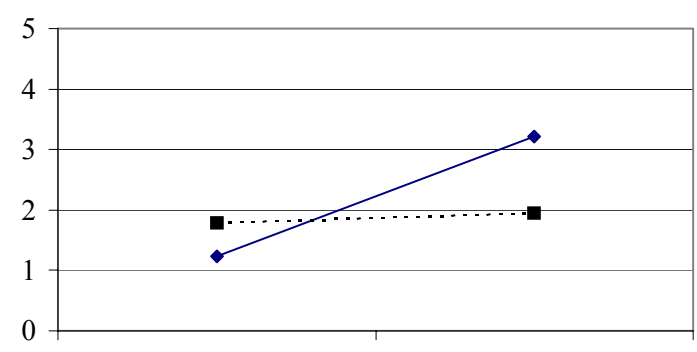

(f) $\mathrm{B}$ - $\mathrm{A}$

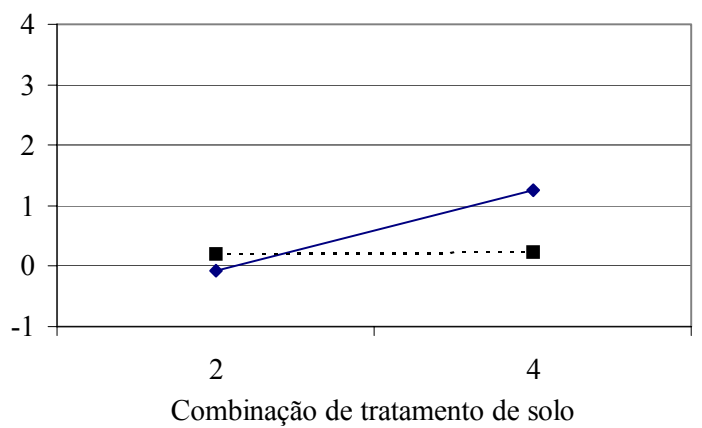

Figura 5 - Massa da matéria fresca de raiz (MFR) de plantas de limão 'Cravo'. Interação sistema de produção (convencional e orgânico) x tratamento de solo (radiação $\gamma$ com e sem $P$. parasitica, radiação $\gamma$ com filtrado e natural). (a) raiz $\mathrm{A}$, (b) raiz $\mathrm{B}$ e (c) B-A nas combinações de tratamentos de solo 1-3; (d) raiz $\mathrm{A}$, (e) raiz $\mathrm{B}$ e (f) B-A nas combinações de tratamentos de solo 2-4. As combinações de tratamentos são: 1 (raiz A: radiação $\gamma$; raiz B: radiação $\gamma$ com filtrado), 2 (raiz A: radiação $\gamma$ com $P$. parasitica; raiz B: radiação $\gamma$ com filtrado), 3 (raiz A: radiação $\gamma$; raiz B: natural), 4 (raiz A: radiação $\gamma \operatorname{com} P$. parasitica; raiz B: natural) 
Seguindo a mesma tendência descrita para o sistema radicular, as plantas não micorrizadas no solo do sistema orgânico tiveram maior teor de fósforo e massa da matéria seca de parte aérea que as plantas não micorrizadas no solo do sistema convencional. No entanto, em condições de solo natural, maiores valores dessas variáveis foram observados nas plantas no solo do sistema convencional (Tabela 7). Também houve efeito da interação de sistema de produção e tratamento de solo sobre essas duas variáveis de parte aérea e nenhum efeito da infestação com $P$. parasitica nas análises 1-3 e 2-4 (Tabela 3 e Figura 6). Com relação aos outros nutrientes na parte aérea, houve diferentes respostas. As plantas associadas aos fungos micorrízicos nativos de ambos os sistemas de produção apresentaram, significativamente, maiores teores de $\mathrm{Cu}$ e $\mathrm{Zn}\left(4,90\right.$ e 17, $\left.43 \mathrm{mg} \mathrm{Kg}^{-1}\right)$ que as plantas não micorrizadas $\left(3,72\right.$ e 14,11 mg Kg ${ }^{-}$ $\left.{ }^{1}\right)$. No entanto, as médias dos teores de $\mathrm{Fe}, \mathrm{Mn}$ e $\mathrm{N}$ foram significativamente maiores nas plantas não micorrizadas $\left(66,33 ; 15,36 \mathrm{mg} \mathrm{Kg}^{-1}\right.$ e $\left.29,01 \mathrm{~g} \mathrm{Kg}^{-1}\right)$ que nas micorrizadas $\left(51,68 ; 12,97 \mathrm{mg} \mathrm{Kg}^{-1}\right.$ e $\left.24,49 \mathrm{~g} \mathrm{Kg}^{-1}\right)$.

As associações micorrízicas formadas a partir das comunidades tanto do sistema convencional como orgânico provocaram um aumento da proteína do sistema radicular somente nas raízes colonizadas (raiz B; Tabelas 4 e 8), demonstrando um efeito local, mas não sistêmico sobre essa variável. Não foram detectadas diferenças na atividade de quitinase em nenhumas das análises de combinações de tratamentos (Tabelas 5 e 8 ). 
Tabela 7. Massa da matéria seca (MSA) e teor de fósforo (P) da parte aérea de plantas de limão 'Cravo' cultivadas em solo dos sistemas de produção convencional e orgânico, considerando as combinações de tratamentos de solo sem FMAs (1-2) e com a FMAs (3-4). As combinações de tratamentos são: 1 (raiz A: radiação $\gamma$; raiz B: radiação $\gamma$ com filtrado), 2 (raiz A: radiação $\gamma \operatorname{com} P$. parasitica; raiz B: radiação $\gamma$ com filtrado), 3 (raiz A: radiação $\gamma$; raiz B: natural), 4 (raiz A: radiação $\gamma$ com $P$. parasitica; raiz B: natural)

\begin{tabular}{|c|c|c|}
\hline & $1-2$ & $3-4$ \\
\hline \multicolumn{3}{|c|}{ MSA (g) } \\
\hline Convencional & 1,27 & $4,30 *$ \\
\hline Orgânico & $2,04 *$ & 2,69 \\
\hline \multicolumn{3}{|c|}{$\mathrm{P}\left(\mathrm{g} \mathrm{Kg}^{-1}\right)$} \\
\hline Convencional & 0,66 & $1,66 *$ \\
\hline Orgânico & $0,82 *$ & 1,31 \\
\hline
\end{tabular}

Nas colunas, $\left(^{*}\right)$ indica que há diferença entre médias pelo teste $\mathrm{F}$ de análise de variância $(\mathrm{P} \leq 0,05)$ 


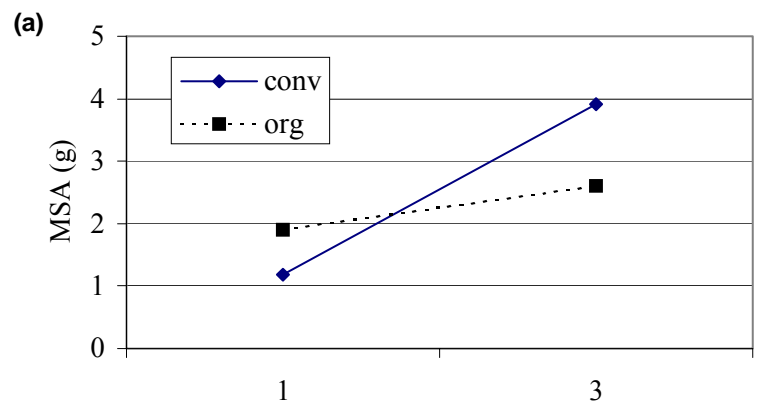

(b)
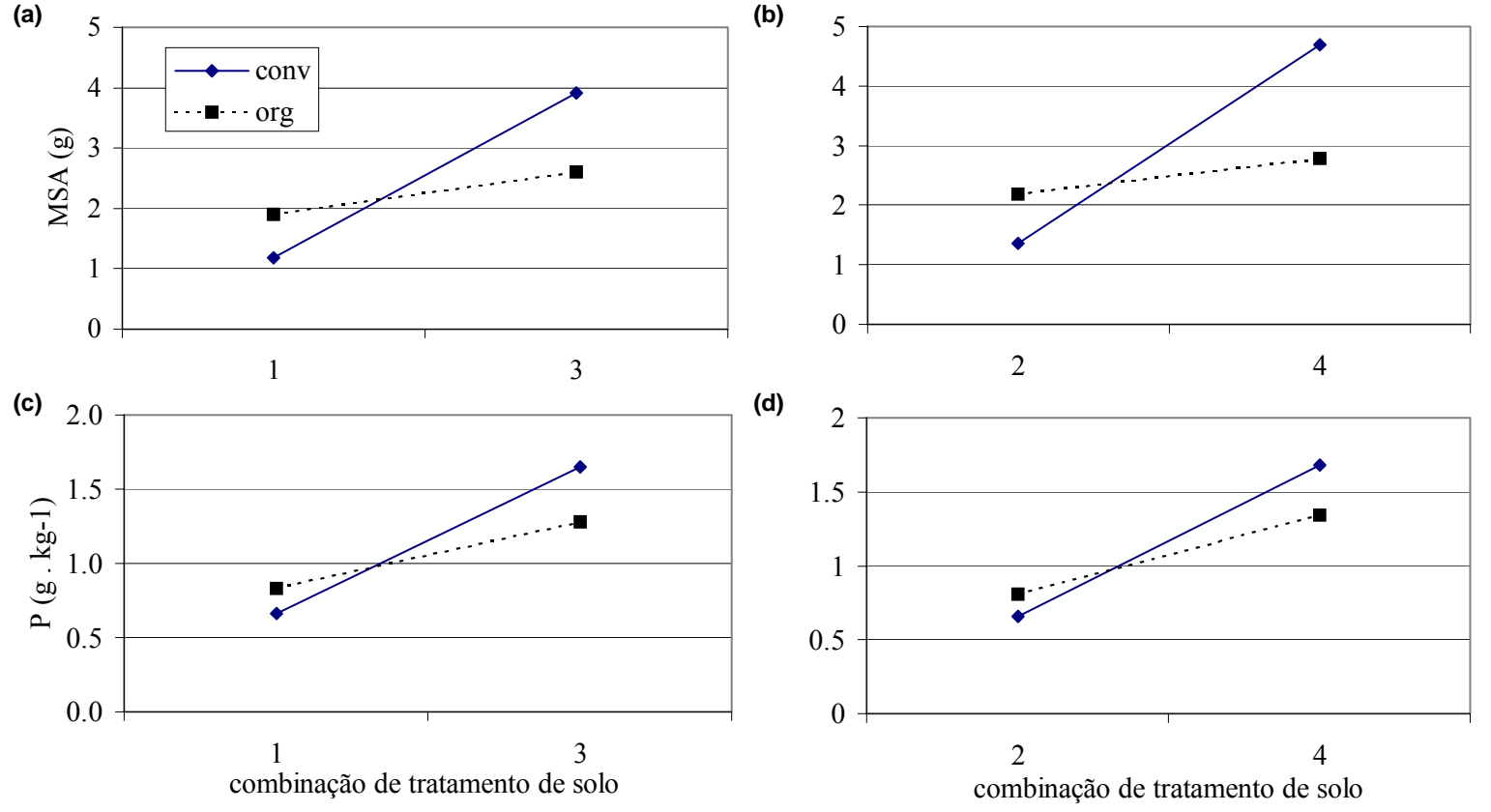

(d)

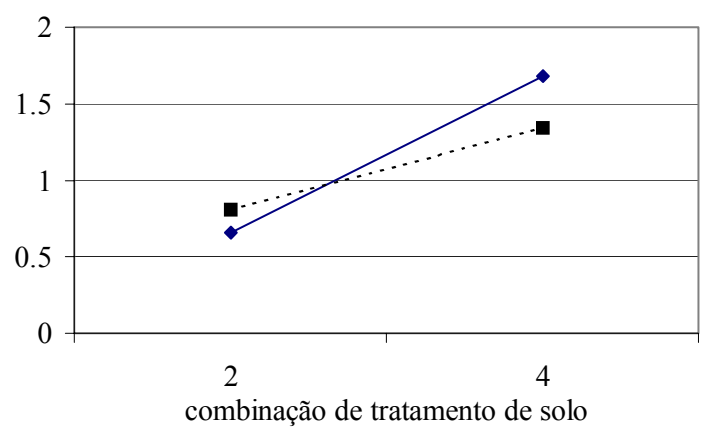

Figura 6 - Massa da matéria seca (MSA) (a e b) e teor de fósforo (P) (c e d) da parte aérea de plantas de limão 'Cravo'. Interação sistema de produção (convencional e orgânico) $\mathrm{x}$ tratamento de solo (combinações). As combinações de tratamentos são: 1 (raiz A: radiação $\gamma$; raiz B: radiação $\gamma$ com filtrado), 2 (raiz A: radiação $\gamma$ com $P$. parasitica; raiz B: radiação $\gamma$ com filtrado), 3 (raiz A: radiação $\gamma$; raiz B: natural), 4 (raiz A: radiação $\gamma \operatorname{com} P$. parasitica; raiz B: natural) 
Tabela 8. Proteína e atividade de quitinase nas raízes A e B de plantas de limão 'Cravo' e a diferença entre as raízes $\mathrm{B}$ e A nas combinações de tratamentos de solo. As combinações de tratamentos são: 1 (raiz A: radiação $\gamma$; raiz B: radiação $\gamma$ com filtrado), 2 (raiz A: radiação $\gamma$ com P. parasitica; raiz B: radiação $\gamma$ com filtrado), 3 (raiz A: radiação $\gamma$; raiz B: natural), 4 (raiz A: radiação $\gamma \operatorname{com} P$. parasitica; raiz B: natural)

\begin{tabular}{|c|c|c|c|c|c|c|}
\hline & \multicolumn{3}{|c|}{$\begin{array}{l}\text { Proteína } \\
\left(\mu \mathrm{g} \mathrm{mL} L^{-1}\right)\end{array}$} & \multicolumn{3}{|c|}{$\begin{array}{c}\text { Atividade de quitinase } \\
\text { (Unidades de absorbância } \min ^{-1} \mathrm{mg} \\
\text { proteína }^{-1} \text { ) }\end{array}$} \\
\hline & A & B & B-A & A & B & B-A \\
\hline 1 & $259^{\text {(a) }}$ & 220 & -39 & 0,228 & 0,260 & 0,032 \\
\hline 2 & 217 & 227 & 11 & 0,267 & 0,246 & $-0,021$ \\
\hline 3 & 244 & $315^{(b)}$ & $70^{(b)}$ & 0,226 & 0,210 & $-0,016$ \\
\hline 4 & 246 & $352^{(\mathrm{c})}$ & $106^{(\mathrm{c})}$ & 0,227 & 0,200 & $-0,027$ \\
\hline
\end{tabular}

Nas colunas, foram comparados separadamente 1 e 2,1 e 3, 3 e 4 e 2 e 4. Médias seguidas de: ${ }^{(a)}$ diferem entre si na comparação 1 e $2 ;{ }^{(b)}$ diferem entre si na comparação 1 e 3 ; $^{\left({ }^{c}\right)}$ diferem entre si na comparação 2 e 4 . Teste $F$ da análise de variância $(P \leq 0,05)$

\subsection{Discussão}

A infestação com $P$. parasitica não afetou o desenvolvimento das plantas de limão 'Cravo' nos experimentos. Com as temperaturas elevadas nos meses em que foram realizadas as infestações (Figura 2), provavelmente, as condições de umidade mantidas nos solos depois da infestação não foram adequadas para o desenvolvimento da doença. Outra possível explicação para esse resultado é que a quantidade de inóculo utilizada não tenha sido suficiente para causar doença nas plantas com sete meses e meio de idade. Em outros porta-enxertos de citros, plantas com mais de três meses de idade (mais de quatro folhas) foram mais resistentes a esse patógeno que plantas mais jovens (Graham, 1990).

O filtrado do solo do sistema orgânico estimulou localmente o crescimento das raízes das plantas de limão 'Cravo' não micorrizadas. Sugere-se que provavelmente 
microrganismos promotores do crescimento estavam presentes no filtrado e ocuparam o vazio biológico causado pela radiação $\gamma$. Queiroz (2003) observou que rizobactérias isoladas da rizosfera de citros e cenoura aumentaram a massa da matéria seca de raiz de plântulas de limão 'Cravo' cultivadas em solo autoclavado, comparadas a testemunha.

A resposta de crescimento das raízes das plantas micorrizadas cultivadas no solo do sistema de produção convencional mostrou que as espécies de fungos micorrízicos envolvidas nessa associação simbiótica promoveram o crescimento radicular não apenas como conseqüência do aumento do crescimento de parte aérea. Foi evidente o efeito local da colonização micorrízica sobre o crescimento da raiz. Davis \& Menge (1980) também relataram esse efeito nas raízes de plantas de laranja doce (Citrus sinensis) colonizadas por Glomus fasciculatum. Em março de 2002, a espécie de FMA mais abundante (número total de esporos) no solo de campo dos sistemas de produção convencional e orgânico foi G. fasciculatum (Capítulo 3). É possível que essa espécie de fungo estivesse colonizando as raízes e contribuindo para o aumento de biomassa de raiz. Fidelibulis et al. (2001) sugeriram que isolados de FMAs que aumentam o crescimento das raízes devem melhorar o desenvolvimento das plantas jovens no campo e diminuir o impacto de períodos secos sobre elas, pois aumentam a exploração das raízes no solo. Nos tratamentos com solo do sistema orgânico, o incremento local de massa das raízes micorrizadas foi pequeno e, proporcionalmente, menor que o incremento sistêmico (raízes não micorrizadas). Pode ser que as espécies de fungos micorrízicos que colonizaram as raízes das plantas no solo natural do sistema orgânico foram diferentes das do sistema convencional e promoveram pouco crescimento local da raiz. No experimento de raiz dividida realizado por Koch \& Johnson (1984), outros dois porta-enxertos de citros, com diferentes níveis de dependência micorrízica, não tiveram aumento local de biomassa radicular quando associados a Glomus intraradices. Porém, esses autores não observaram menor efeito local que sistêmico no crescimento das raízes. Portanto, somente a diferença de isolados de FMAs não explica os resultados obtidos no presente estudo. Sugere-se que patógenos de raiz interagiram com os fungos micorrízicos e o saldo foi o pouco crescimento local da raiz. Apesar de não ter sido avaliada a severidade de podridão de raízes, supõe-se que patógenos de raiz estavam 
presentes nos solos naturais de ambos os sistemas por dois motivos. Primeiro, porque foi necessário usar o artifício de verter solo irradiado perto das raízes no momento do transplante para evitar morte das plantas (ver material e métodos). Segundo, porque no final dos experimentos, do solo natural foi recuperado $P$. parasitica nas iscas com folhas de citros. Não se descarta a possibilidade de que alguma interação dessa natureza tenha ocorrido também no solo natural do sistema convencional, mas como já foi comentado, o saldo foi positivo para o crescimento das raízes micorrizadas.

O custo da simbiose foi menor que o benefício (produção de biomassa) para as plantas cultivadas nos solos de ambos os sistemas de produção. Vários outros experimentos, sem divisão de raízes, foram realizados com as comunidades de FMAs nativas desses dois sistemas (Capítulos 4 e 5). Esse efeito evidente de resposta micorrízica positiva só tinha sido observado com o uso do fungicida benomyl para obtenção de testemunhas não micorrizadas (capítulo 4). O benomyl afetou a simbiose parcialmente e diminuiu seu custo para as plantas, resultando em plantas com maior biomassa que aquelas com a simbiose original. Propõe-se que a divisão de raízes proporcionou um efeito final similar ao do benomyl. Como somente metade do sistema radicular foi colonizado, a colonização de $90 \%$ obtida significa na realidade $45 \%$. Portanto, os resultados indicam que as espécies de FMAs trazidas diretamente do solo dos pomares de plantas adultas de citros colonizam agressivamente as plantas jovens na casa de vegetação e não promovem respostas positivas ou, que as condições de cultivo em vasos em casa de vegetação favorecem as espécies de fungos micorrízicos com esse comportamento.

Aproximadamente, $40 \%$ mais de proteína foi observada nas raízes micorrizadas de limão 'Cravo' comparadas a raízes não micorrizadas (Tabela 8). O efeito foi local, visto que as raízes não micorrizadas de plantas micorrizadas tiveram teores de proteína similares aos das plantas não micorrizadas. Em trevo (Arines et al., 1993), ervilha (Samra et al., 1997) e tomate (Pozo et al., 2002) também foi observado o aumento de proteína nas raízes micorrizadas. Tanto no presente estudo, como nos outros citados, as proteínas detectadas nas análises podem ser de origem vegetal ou fúngica, pois toda a raiz foi macerada no procedimento de extração. Com o estabelecimento da simbiose 
micorrízica, mudanças no padrão de polipeptídeos ocorrem, podendo haver decréscimo ou aumento daqueles já existentes (constitutivos), ou síntese de novos polipeptídeos (Arines et al., 1993). Segundo revisado por Gianinazzi-Pearson \& Gianinazzi (1995), no final dos anos 80 e início dos 90 foram publicados os primeiros estudos mostrando a síntese de novos polipeptídeos em resposta a infecção micorrízica, e foram chamados endomicorrizinas. Mais recentemente, as endomicorrizinas têm sido chamadas polipeptídeos relacionados com a simbiose (SR polipeptídeos, do inglês) (Samra et al., 1997). Ainda se conhece pouco sobre as funções dessas novas proteínas que aparecem somente nas raízes micorrizadas. Entre essas proteínas, já foram identificadas isoformas das enzimas quitinase (Pozo et al., 1996), chitosanase, $\beta-1,3$ glucanase (Pozo et al., 2002) e superóxido dismutase (Arines et al., 1993; Pozo et al., 2002). Pelo fato de que essas isoformas variam com a planta, mas não com a espécie de fungo envolvida na simbiose, supõe-se que são de origem vegetal (Gianinazzi-Pearson \& Gianinazzi, 1995; Pozo et al., 1998). Porém, não se pode desconsiderar a possível contribuição de proteínas de origem fúngica no aumento do conteúdo de proteína nas raízes micorrizadas.

Geralmente, a atividade de qitinase nas raízes micorrizadas aumenta nas fases iniciais da colonização e, posteriormente, decresce a níveis inferiores àqueles observados nas raízes de plantas não micorrizadas (Dumas-Gaudot et al., 1996). Lambais \& Mehdy (1993) observaram esse fenômeno nas raízes de plantas de feijão associadas a G. intraradices: na quarta semana depois do plantio, a atividade de quitinase nas raízes micorrizadas $(5 \%$ de colonização) foi maior que nas não micorrizadas e da sexta semana $(30 \%$ de colonização) até a décima $(70 \%$ de colonização), a situação se inverteu. No experimento 3 do capítulo 4, plantas de limão 'Cravo', com sete meses de idade e com mais de $90 \%$ de colonização micorrízica, apresentaram aproximadamente 30\% menos de atividade dessa enzima nas raízes micorrizadas comparadas a não micorrizadas (dados não apresentados), confirmando o decréscimo relatado. Em experimentos com raízes divididas de tomate e o fungo micorrízico Glomus mosseae, Pozo et al. (2002) observaram nas plantas micorrizadas, além das isoformas constitutivas, a indução local de uma nova isoforma ácida de 
quitinase nas raízes micorrizadas $(50 \%$ de colonização), ausente nas raízes não micorrizadas dessas mesmas plantas. Ou seja, esses autores constataram uma reação local das plantas à associação simbiótica, por meio do incremento dessa proteína PR. No presente estudo com raízes divididas de limão 'Cravo', as raízes micorrizadas (raiz B), com colonização superior a 90\%, e as não micorrizadas (raiz A) das plantas micorrizadas (combinações 3 e 4, Figura 1), não apresentaram diferenças na atividade de quitinase (Tabela 8). Considerando que a indução de nova isoforma de quitinase foi local nas raízes das plantas de tomate micorrizadas (Pozo et al., 2002), esperava-se que da mesma maneira, o decréscimo da atividade dessa enzima, observada nas plantas de limão 'Cravo' micorrizadas no experimento 3 do capítulo 4, também aparecesse localmente nas raízes micorrizadas do presente estudo. No entanto, isso não ocorreu. Um dos possíveis fatores que poderiam ter influenciado esses resultados é o estágio da formação micorrízica. As plantas de limão do experimento 3 do capítulo 4 tinham sete meses de idade e estavam em contato com inóculo de FMAs desde o plantio das sementes. As plantas do presente estudo também tinham essa idade, porém permaneceram em areia autoclavada até o transplante para os vasos com os diferentes tratamentos, aproximadamente aos três meses de idade. Portanto, 90\% da colonização observada aos quatro meses do transplante pode corresponder a um estágio diferente do processo de colonização micorrízica daquele observado nas plantas do experimento 3 do capítulo 4. Não se encontrou na literatura revisada, estudos sobre atividade de quitinase nas raízes de plantas associadas a FMAs nativos, sempre um isolado específico foi testado. São necessários mais estudos sobre as reações das plantas à associação micorrízica com FMAs nativos.

\subsection{Conclusões}

Não foi possível avaliar a capacidade indutora de resistência dos fungos micorrízicos arbusculares nativos porque não houve desenvolvimento da podridão de raízes nas plantas de limão 'Cravo' após a infestação com $P$. parasitica.

A atividade de quitinase foi igual nas raízes de plantas micorrizadas e não micorrrizadas cultivadas nos solos dos sistemas de produção convencional e orgânico. 


\section{CONCLUSÕES GERAIS}

- A porcentagem de colonização micorrízica nas plantas cítricas, tanto no campo como na casa de vegetação, foi elevada (próximo a 90\%), independente do manejo convencional ou orgânico;

- Em março de 2002, observou-se maior diversidade de espécies de fungos micorrízicos no solo do sistema orgânico que no solo do convencional;

- A radiação $\gamma$ foi mais adequada que a aplicação de benomyl para obtenção de testemunha não micorrizada para estudos de interação de comunidade de FMAs nativos e $P$. parasitica;

- Não foi possível avaliar a capacidade dos FMAs nativos em reduzir a severidade de podridão de raízes causada por $P$. parasitica em plantas de limão 'Cravo' porque a doença não se manifestou nas plantas cultivadas nos solos irradiados, onde o patógeno foi inoculado. Porém, a podridão de raízes ocorreu nas plantas cultivadas nos solos naturais provenientes dos dois sistemas de produção, sendo que, em geral, maior severidade foi observada nas plantas cultivadas no solo do sistema orgânico;

- A atividade de quitinase, independente do tipo de manejo, foi similar nas raízes micorrizadas e não micorrizadas de plantas de limão 'Cravo', no quarto e quinto mês depois de transplantadas da areia autoclavada para o solo com os respectivos tratamentos. 


\section{REFERÊNCIAS BIBLIOGRÁFICAS}

ABBOTT, L.K.; GAZEY,C. An ecological view of the formation of VA mycorrhizas.

Plant and Soil, v.159, n.1, p.69-78, 1994.

AGNANI, D.R.G. Interação de fungos micorrízicos arbusculares, agentes de controle biológico e Phytophthora parasitica em limoeiro cravo (Citrus limonia). Piracicaba, 2002. 71p. Dissertação (Mestrado) - Escola Superior de Agricultura "Luiz de Queiroz", Universidade de São Paulo.

AGUIAR, R.C. Abrindo o pacote tecnológico: Estado e pesquisa agropecuária no Brasil. São Paulo: Polis; Brasília: CNPq, 1986. 156p.

ALEF, K.; NANNIPIERI, P. Cellulase activity. In: ALEF, K., NANNIPIERI, P. (Ed.). Methods in applied soil microbiology and biochemistry. San Diego: Academic Press, 1995. p.345-349.

ALEXOPOULOS, C.J.; MIMS, C.W.; BLACKWELL, M. Introductory mycology. New York: John Wiley, 1996. 868p.

ALTIERI, M.A. A sustentabilidade da agricultura orgânica. Agroecologia-hoje, n.7, p.5-7, 2001

ALTIERI, M.A. Entrevista. Agricultura Sustentável, v.2, p.5-11, 1995.

AMPARO, A. Manejo orgânico de citrus: farinha de rocha, bioestimulantes e biomassa. In: ENCONTRO DE CITRICULTURA SUSTENTÁVEL, 2., Limeira, 2001. Resumos. Campinas: s. ed., 2001. p.39-43.

ARAÚJO, J.R.G. Caracterização química, bioquímica e horticultural de microtangerinas (Citrus spp.), de valor potencial como porta-enxertos. Botucatu, 1998. 155p. Tese (Doutorado) - Universidade Estadual de São Paulo. 
ARINES, J.; PALMA, J.M.; VILARINO, A. Comparison of protein patterns in nonmycorrhizal and vesicular-arbuscular mycorrhizal roots of red clover. New Phytologist, v.123, n.4, p.763-768, 1993.

AZCÓN-AGUILAR, C.; BAREA, J.M. Arbuscular mycorrhizas and biological control of soil-borne plant pathogens - an overview of the mechanisms involved. Mycorrhiza, v.6, n.6, p.457-464, 1996.

BARCELÓ C., J.; NICOLÁS R., G.; SABATER G., B.; SÁNCHEZ T., R. Fisiología vegetal. Madrid: Ediciones Pirámide, 1980. 750p.

BARTNICKI-GARCIA, S.; WANG, M.C. Biochemical aspects of morphogenesis in Phytophthora. In: ERWIN, D.C.; BARTNICKI-GARCIA, S.; TSAO, P.H. Phytophthora: its biology, taxonomy, ecology, and pathology. St. Paul: APS, 1983. p.121-137.

BATAGLIA, O.C.; FURLANI, A.M.C.; TEIXEIRA, J.P.F.; FURLANI, P.R.; GALLO, J.R. Métodos de análise química de plantas. Campinas: Instituto Agronômico, 1983. 48p. (Circular, 78).

BEG. The International Bank of The Glomeromycota. $<$ http.//www.ukc.ac.uk/bio/beg $>$ (10 maio 2003).

BØDER, L.; KJØLLER, R.; KRISTENSEN, K.; ROSENDAHL, S. Interactions between indigenous arbuscular mycorrhizal fungi and Aphanomyces euteiches in field-grown pea. Mycorrhiza, v.12, n.1, p.7-12, 2002.

BRADFORD, M.M. A rapid and sensitive method for the quantification of microgram quantities of protein utilizing the principle of protein-dye binding. Analytical Biochemistry, v.72, p.248-254, 1976.

CADE-MENUN, B.J.; BERCH, S.M. Response of mycorrhizal western red cedar to organic phosphorus sources and benomyl. Canadian Journal of Botany, v.75, n.8, p.1226-1235, 1997.

CALDEIRA, S.F.; CHAVES,G.M.; ZAMBOLIM, L. Associação de micorriza vesicular-arbuscular com café, limão-rosa e capim-gordura. Pesquisa Agropecuária Brasileira, v.18, n.2, p.223-228, 1983. 
CARDOSO, E.J.B.N.; FREITAS, S.S. A rizosfera. In: CARDOSO, E.J.B.N.; TSAI, S.M.; NEVES, M.C.P. (Coord.). Microbiologia do solo. Campinas: Sociedade Brasileira de Ciência do Solo, 1992. p.41-57.

CARRENHO, R.; BONONIN,V.L.R.; GRACIOLLI, L.A. Effect of the fungicides Fosetyl-Al and Metalaxyl on arbuscular mycorrhizal colonization of seedlings of Citrus sinensis (L.) Osbeck grafted onto C. limon (L.) Burmf. Acta Scientiarum, v.22, n.2, p.305-310, 2000 .

CARVALHO, J.E.B.; BRITO, Z.U.; COSTA NETO, A.O.; CALDAS, R.C. Efeito de práticas culturais sobre o estabelecimento e permanência de fungos micorrízicos arbusculares (MAS) na laranja 'Pera'. Revista Brasileira de Fruticultura, v.17, n.3, p.33-46, 1995.

CHEN, S.; EDWARDS, C.A.; SUBLER, S. A microcosm approach for evaluating the effects of the fungicides benomyl and captan on soil ecological processes and plant growth. Applied Soil Ecology, v.18, n.1, p.69-82, 2001.

CLAY, K. Mycophyllas and mycorrhizas: comparisons and contrasts. In: READ, D.J.; FITTER, A.H.; ALEXANDER, I.J.(Ed.). Mycorrhizas in ecosystems. Cambridge, UK: CAB International, 1992. p.13-25.

COOK, R.J. Twenty-five years of progress towards biological control. In: HORNBY, D (Ed.). Biological control of soil-borne plant pathogens. Wallingford: CABI, 1993. p.1-14.

CORDIER, C.; GIANINAZZI, S.; GIANINAZZI-PEARSON, V. Colonisation patterns of root tissues by Phytophthora nicotianae var. parasitica related to reduced disease in mycorrhizal tomato. Plant and Soil, v.185, n.2, p.223-232, 1996.

CORDIER, S.; POZO, M.J.; BAREA, J.M.; GIANINAZZI, S.; GIANINAZZIPEARSON, V. Cell defence responses associated with localized and systemic resistance to Phytophthora parasitica in tomato by arbuscular mycorrhizal fungus. Molecular Plant Microbe Interactions, v.11, n.10, p.1017-1028, 1998.

CUENCA, G.; MENESES, E. Diversity patterns of arbuscular mycorrhizal fungi associated with cacao in Venezuela. Plant and Soil, v.183, n.2, p.315-322, 1996. 
D'ANDRÉA, P.A. Manejo dos processos de produção de citrus sustentável. In: ENCONTRO DE CITRICULTURA SUSTENTÁVEL, 2., Limeira, 2001. Resumos. Campinas: s. ed., 2001. p.59-64.

DAVIS, R.M. Mycorrhizal fungi associated with citrus in south Texas. Journal Rio Grande Valley Horticultural Society, v.35, p.127-129, 1982.

DAVIS, R.M.; MENGE, J.A. Influence of Glomus fasciculatus and soil phosphorus on Phytophthora root rot of citrus. Phytopathology, v.70, n.5, p.447-452, 1980.

DAVIS, R.M.; MENGE, J.A. Phytophthora parasitica inoculation and intensity of vesicular-arbuscular mycorrhizae in citrus. New Phytologist, v.87, n.4, p.705-715, 1981.

DEFFUNE, G. Potenciais e perspectivas da alelodinâmica e indução de resistência sistêmica vegetal na citricultura orgânica. In: ENCONTRO DE CITRICULTURA SUSTENTÁVEL, 2., Limeira, 2001. Resumos. Campinas: s. ed., 2001. p.38-84.

DOOD, J.C.; BODDINGTON, C.L.; RODRIGUEZ, A.; GONZALEZ-CHAVEZ, C.; MANSUR, I. Mycelium of arbuscular mycorrhizal fungi (AMF) from different genera: form, function and detection. Plant and Soil, v.226, n.2, p.131-151, 2000.

DOWNER, A.J.; MENGE, J.A.; POND, E. Association of cellulytic enzyme activities in eucalyptus mulches with biological control of Phytophthora cinnamomi. Phytopathology, v.91, n.9, p.847-855, 2001.

DUMAS-GAUDOT, E.; SLEZACK, S.; DASSI, B.; POZO, M.J.; GIANINAZZIPEARSON, V.; GIANINAZZI, S. Plant hydrolytic enzymes (chitinases and $\beta-1,3-$ glucanases) in root reactions to pathogenic and symbiotic microorganisms. Plant and Soil, v.185, n.2, p.211-221, 1996.

FEICHTENBERGER, E. Doenças incitadas por Phytophthora em citros. In: LUZ, E.D.M.N.; SANTOS, A.F.; MATSUOKA, K.; BEZERRA, J.L. (Ed.). Doenças causadas por Phytophthora no Brasil. Campinas: Livraria Rural, 2001. p.283-342.

FIDELIBUS, M.W.; MARTIN, C.A.; STUTZ, J.C. Geographic isolates of Glomus increase root growth and whole-plant transpiration of Citrus seedlings grown with high phosphorus. Mycorrhiza, v.10, n.5, p.231-236, 2001. 
FORTES NETO, P. Degradação de biossólido incorporado ao solo avaliada através de medidas microbiológicas. Piracicaba, 2000. 113p. Tese (Doutorado) - Escola Superior de Agricultura "Luiz de Queiroz", Universidade de São Paulo.

FREITAS, G.B. de. Produção orgânica de fruteiras tropicais. In. ZAMBOLIM, L. (Ed.). Manejo integrado; produção integrada; fruteiras tropicais; doenças e pragas. Viçosa: O autor, 2003. p.61-94.

FUNDECITRUS Fundo de Defesa da Citricultura. <http://www.fundecitrus.com.br $>$ (20 jan. 2004).

FUSCONI, A., GNAVI, E.; TROTTA, A., BERTA, G. Apical meristems of tomato roots and their modifications induced by arbuscular mycorrhizal and soilborne pathogenic fungi. New Phytologist, v.142, n.3, p.505-516, 1999.

GERDEMANN, J.W.; NICOLSON, T.H. Spores of mycorrhizal Endogone species extracted from soil by sieving and decanting. Transaction of Britsh Mycological Society, v.46, p.235-246, 1963.

GHINI, R. Alternativas para substituir o brometo de metila na agricultura. Summa Phytopathologica, v.27, n.1, p.162, 2001.

GIANINAZZI-PEARSON, V.; GIANINAZZI, S. Modulation of defence responses and induced resistance by mycorrhizal fungi: an enigma? In: INTERNATIONAL SYMPOSIUM OF INDUCED RESISTANCE TO PLANT DISEASES, Corfu, 2000. Resumos. Corfu: Eris Tjamos, 2000. p.53.

GIANINAZZI-PEARSON, V.; GIANINAZZI, S. Proteins and protein activities in endomycorrhizal symbioses. In: VARMA, S.; HOCK, B. (Ed) Mycorrhiza structure, function, molecular biology and biotechnology. Berlin: SpringerVerlag, 1995. p.251-266.

GIOVANNETTI, M.; MOSSE, B. An evaluation of techniques for measuring vesicular arbuscular mycorrhizal infection in roots. New Phytologist, v.84, n.3, p.489-500, 1980.

GRAHAM, J.H. Evaluation of citrus rootstocks to Phytophthora root rot in chlamydospore-infested soil. Plant Disease, v.74, n.10, p.743-746, 1990. 
GRAHAM, J.H. What do root pathogens see in mycorrhizas? New Phytologist, v.149, n.3, p.357-359, 2001.

GRAHAM, J.H.; ABBOTT, L.K. Wheat responses to aggressive and non-aggressive arbuscular mycorrhizal fungi. Plant and Soil, v.220, n.1/2, p.207-218, 2000.

GRAHAM, J.H.; EGEL, D.S. Phytophthora root rot development on mycorrhizal and phosphorus-fertilized nonmycorrhizal sweet orange seedlings. Plant Disease, v.72, n.7, p.611-614, 1988.

GRAHAM, J.H.; EISSENSTAT, D.M. Field evidence for the carbon cost of citrus mycorrhizas. New Phytologist, v.140, n.1, p.103-110, 1998.

GRAHAM, J.H.; EISSENSTAT, D.M. Host genotype and the formation of VA mycorrhizae. Plant and Soil, v.159, n.1, p.179-185, 1994.

GRAHAM, L.S.; STICKLEN, M.B. Plant chitinases. Canadian Journal of Botany, v.72, n.8, p.1057-1083, 1994.

GRAVENA, S. Controle integrado de pragas dos citros. In: RODRIGUEZ, O.; VIÉGAS, C.P. (Coord.). Citricultura brasileira. Campinas: Fundação Cargill, 1980. p.645-690.

GRIMM, G.R.; ALEXANDER, A.F. Citrus leaf pieces as traps for Phytophthora parasitica from soil slurries. Phytopathology, v.63, p.540-541, 1973.

HANDElSMAN, J.; STABB, E.V. Biocontrol of soilborne pathogens. The Plant Cell, v.8, n.10, p.1855-1869, 1996.

INVAM. International Culture Collection of (Vesicular) Arbuscular Mycorrhizal Fungi. $<$ http://invam.caf.wvu.edu> ( 10 maio 2003).

JEFRIES, P.; GIANINAZZI, S.; PEROTTO, S.; TURNAU, K.; BAREA, J.M. The contribution of arbuscular mycorrhizal fungi in sustainable maintenance of plant health and soil fertility. Biology and Fertility of Soils, v.37, p.1-16, 2003.

JESUS, E.L. de. Da agricultura alternativa à agroecologia: para além das disputas conceituais. Agricultura Sustentável, v.3, p.13-27, 1996.

JOHNSON, N.C.; GRAHAM, J.H.; SMITH, F.A. Functioning of mycorrhizal associations along the mutualism-parasitism continuum. New Phytologist, v.135, n.4, p.575-585, 1997. 
KAHILUOTO, H.; KETOJA, E.; VESTBERG, M. Creation of a non-mycorrhizal control for a bioassay of AM effectiveness. 1. Comparison of methods. Mycorrhiza, v.9, n.5, p.241-258, 2000.

KAHILUOTO, H.; VESTBERG, M. Creation of a non-mycorrhizal control for a bioassay of AM effectiveness. 2. Benomyl application and soil sampling time. Mycorrhiza, v.9, n.5, p.259-270, 2000.

KIERS, E.T.; WEST, S.A.; DENISON, R.F. Mediating mutualisms: farm management practices and evolutionary changes in symbiont co-operation. Journal of Applied Ecology, v.39, n.5, p.745-754, 2002.

KLEPPER, B. Root-shoot relationships. In: WAISEL, Y.; ESHEL, A.; KAFKAFI, U. (Ed). Plant roots. The hidden half. New York: Marcell Dekker, 1991. p.265-286.

KOCH, K.E.; JOHNSON, C.R. Photosynthate partitioning in split-root citrus seedlings with mycorrhizal and nonmycorrhizal root systems. Plant Physiology, v.75, n.1, p.26-30, 1984.

LAMBAIS, M.R.; MEHDY, M.C. Suppression of endochitinase, $\beta$-1,3-endoglucanase, and chalcone isomerase expression in bean vesicular-arbuscular mycorrhizal roots under different soil phosphate conditions. Molecular Plant-Microbe Interactions, v.6, n.1, p.75-83, 1993.

LARSEN, J.; THINGSTRUP, I.; JAKOBSEN, I. Benomyl inhibits phosphorus transport but not fungal alkaline phosphatase activity in a Glomus-cucumber symbiosis. New Phytologist, v.132, n.1, p.127-133, 1996.

LEWIS, D.H. Symbiosis and mutualism: crisp concepts and soggy semantics. In: BOUCHER, D.H. (Ed.). The biology of mutualism. Ecology and evolution. New York: Oxford University Press, 1985. p.29-39.

MARSCHNER, H. Mineral nutrition of higher plants. Cambridge: Academic Press, 1995. 889p.

MAY, L.L.; KIMATI, H. Produção de inóculo de Phytophthora parasitica dos citros. Agrárias, v.16, n.1/2, p.95-98, 1997. 
MAYER, R.T.; SHAPIRO, J.P.; BERDIS, E.; HEARN, C.J.; McCOLLUM, T.G.; McDONALD, R.E.; DOOSTDAR, H. Citrus rootstock responses to herbivory by larvae of the sugarcane rootstock borer weevil (Diaprepes abbreviatus). Physiologia Plantarum, v.94, n.1, p.164-173, 1995.

MELLO, O.F.; ROSSETTI, V.; AZEVEDO, D.; POMPEU JUNIOR, J. Estudo comparativo da resistência a Phythophthora citrophthora ( $\mathrm{Sm}$ e $\mathrm{Sm}$ ) Leonian e $P$. parasitica Dastur, de onze variedades de Citrus sinensis (Linn.) Osb. usadas como porta-enxertos para laranja Hamlin de clone nucelar e clone velho. In: CONGRESSO BRASILEIRO DE FRUTICULTURA, Campinas, 1971. Anais. Campinas: Sociedade Brasileira de Fruticultura, 1971. v.2. p.489-503.

MICHEL-ROSALES, A.; VALDÉS, M. Arbuscular mycorrhizal colonization of lime in different agroecosystems of the dry tropics. Mycorrhiza, v.6, n.2, p.105-109, 1996.

MOREIRA, F.M.S.; SIQUEIRA, J.O. Microbiologia e bioquímica de solo. Lavras: UFLA, 2002. 626p.

MOREIRA-SOUZA, M.; CARDOSO, E.J.B.N. Dependência micorrízica de Araucaria angustifolia (Bert.) O. Ktze. sob doses de fósforo. Revista Brasileira de Ciência do Solo, v.26, n.4, p.905-912, 2002.

MOREIRA-SOUZA, M.; TRUFEM, S.F.B.; GOMES-DA-COSTA, S.M.; CARDOSO, E.J.B.N. Arbuscular mycorrhizal fungi associated with Araucaria angustifolia (Bert) O. Ktze. Mycorrhiza, v.13, n.4, p.211-215, 2003.

MÜLLER, G.W. Moléstias de vírus e micoplasmas de citros. In: RODRIGUEZ, O.; VIÉGAS, C.P. (Coord.). Citricultura brasileira. Campinas: Fundação Cargill, 1980. p.565-607.

NEMEC, S.; MENGE, J.A.; PLATT, R.G.; JOHNSON, L.V. Vesicular-arbuscular mycorrhizal fungi associated with citrus in Florida and California and notes of their distribution and ecology. Mycologia, v.73, p.112-127, 1981.

NEVES, E.M.; DAYOUB, M.; DRAGONE, D.S.; NEVES, M.F. Citricultura brasileira: efeitos econômico-financeiros, 1996-2000. Revista Brasileira de Fruticultura, v.23, n.2, p.432-436, 2001. 
NOGUEIRA, M.A.; CARDOSO, E.J.B.N. Produção de micélio externo de fungos micorrízicos arbusculares e crescimento da soja em função de doses de fósforo. Revista Brasileira de Ciência do Solo, v.24, n.2, p.329-338, 2000.

OLIVEIRA, A.A.R.; COELHO, Y.S. Infecção micorrízica em pomares de citros no Estado de Sergipe. Revista Brasileira de Fruticultura, v.17, n.3, p.77-84, 1995.

OLIVEIRA, A.A.R.; COELHO, Y.S. MATTOS, C.R.R. Infecção micorrízica em pomares de citros no Estado da Bahia. In: CONGRESSO BRASILEIRO DE FRUTICULTURA, 8., Brasília, 1986. Anais. Brasília: Sociedade Brasileira de Fruticultura. p.195-198.

PENG, S.; EISSENSTAT, D.M.; GRAHAM, J.H.; WILLIAMS, K.; HODGE, N.C. Growth depression in mycorrhizal citrus at high-phosphorus supply. Analysis of carbon costs. Plant Physiology, v.101, n.3, p.1063-1071, 1993.

PENTEADO, S.R. Introdução à agricultura orgânica - Normas e técnicas de cultivo. Campinas: Grafimagem, 2000. 110p.

PERRIN, R.; PLENCHETTE, C. Effect of some fungicides applied as soil drenches on the mycorrhizal infectivity of two cultivated soils and their receptiveness to Glomus intraradices. Crop Protection, v.12, n.2, p.127-133, 1993.

PINHEIRO, S.; BARRETO, S.B. MB-4 - Agricultura sustentável, trofobiose e biofertilizantes. Florianópolis: Universidade de Santa Catarina, 1997. 273p.

POZO, M.J.; AZCÓN-AGUILAR, C.; DUMAS-GAUDOT, E.; BAREA, J.M. Chitosanase and chitinase activities in tomato roots during interactions with arbuscular mycorrhizal fungi or Phytophthora parasitica. Journal of Experimental Botany, v.49, n.327, p.1729-1739, 1998.

POZO, M.J.; CORDIER, C; DUMAS-GAUDOT, E.; GIANINAZZI, S.; BAREA, J.M.; AZCÓN-AGUILAR, C. Localized versus systemic effect of arbuscular mycorrhizal fungi on defence responses to Phytophthora infection in tomato plants. Journal of Experimental Botany, v.53, n.368, p.525-534, 2002. 
POZO, M.J.; DUMAS-GAUDOT, E.; SLEZACK, S; CORDIER, C; ASSELIN, A.; GIANINAZZI， S.; GIANINAZZI-PEARSON， V.; AZCÓN-AGUILAR， C.; BAREA, J.M. Induction of new chitinase isoforms in tomato roots during interactions with Glomus mosseae and/or Phytophthora nicotianae var. parasitica. Agronomie, v.16, n.10, p.689-697, 1996.

QUEIROZ, B.P.V. Isolamento e seleção de rizobactérias para a promoção de crescimento e controle de Phytophthora parasitica em citros. Rio Claro, 2003. 120p. Tese (Doutorado) - Instituto de Biociências, Universidade Estadual Paulista "Júlio de Mesquita Filho".

REGO, I.A.C. Efeito de diferentes práticas culturais adotadas em pomar de laranja 'Pêra' (Citrus sinensis L. OsbecK) sobre a eficiência de fungos micorrízicos arbusculares nativos e ocorrência de espécies. Cruz das Almas, 2000. 54p. Dissertação (Mestrado) - Universidade Federal da Bahia.

REIJNTJES, C.; HAVERKORT, B.; WATERS-BAYER, A. Agricultura para o futuro: uma introdução à agricultura sustentável e de baixo uso de insumos externos. Trad. de J.C. Comerford. Rio de Janeiro: AS-PTA, 1994. 324p.

RIBEIRO, O.K. Physiology of assexual sporulation and spore germination in Phytophthora. In: ERWIN, D.C.; BARTNICKI-GARCIA, S.; TSAO, P.H. Phytophthora: its biology, taxonomy, ecology, and pathology. St. Paul: APS, 1983. p.55-70.

RODRIGUEZ, O. Nutrição e adubação dos citros. In: RODRIGUEZ, O.; VIÉGAS, F.C.P. (Ed.). Citricultura brasileira. Campinas: Fundação Cargill, 1980. cap.15. p.385-428.

RODRÍGUEZ-KÁBANA, R.; CALVET, C. Capacidad del suelo para controlar enfermedades de origen edáfico. Fitopatologia Brasileira, v.19, n.2, p.129-138, 1994.

ROSSETTI, V. Doenças dos citros. In: RODRIGUEZ, O.; VIÉGAS, C.P. (Coord.).

Citricultura brasileira. Campinas: Fundação Cargill, 1980. p.517-563. 
SAMRA, A.; DUMAS-GAUDOT, E.; GIANINAZZI, S. Detection of symbiosis related polypeptides during the early stages of the stablishment of arbuscular mycorrhiza between Glomus mosseae and Pisum sativum roots. New Phytologist, v.135, n.4, p.711-722, 1997.

SANTOS, C.D. Efeitos do uso de herbicidas em solo cultivado com citros (Citrus sinensis L. Osbeck) sobre a população de fungos micorrízicos vesículo-arbusculares. Piracicaba, 1989. 74p. Dissertação (Mestrado) - Escola Superior de Agricultura "Luiz de Queiroz", Universidade de São Paulo.

SCHUBERT, A.;AIASSA, A.; PALAZZO, D.; VANADIA, S Ocurrence of mycorrhiza in citrus orchards in the metaponto area of Basilicata (Italy). Acta Horticulturae, n.324, p.61-66, 1993.

SILVEIRA, A.P.D. Micorrizas. In: CARDOSO, E.J.B.N.; TSAI, S.M.; NEVES, M.C.P. (Coord.). Microbiologia do solo. Campinas: Sociedade Brasileira de Ciência do Solo, 1992. p.257-282.

SINGH, R.S.; SINGH, H.; KANG, M.S. Effect of soil depth and seasonal change on spore population and mycorrhizal colonization of kinnow and rough lemon seedlings. Indian Phytopathology, v.45, n.2, p.337-343, 1992.

SIQUEIRA, J.O; COLOZZI-FILHO, A.; OLIVEIRA, E. Ocorrência de micorrizas vesicular-arbusculares em agro e ecossistemas do Estado de Minas Gerais. Pesquisa Agropecuária Brasileira, v.24, n.12, p.1499-1506, 1989.

SMITH, F.A.; SMITH, S.E. Structural diversity in (vesicular)-arbuscular mycorrhizal symbioses. New Phytologist, v.137, n.3, p.373-388, 1997.

SMITH, S.E. Soil microbes and plants - raising interest, mutual gains. New Phytologist, v.156, n.2, p.142-144, 2002.

SOUZA, P.V.D.; SCHMITZ, J.A.K.; FREITAS, R.S.; CARNIEL, E.; CARRENHO, R. Identificação e quantificação de fungos micorrízicos arbusculares autóctones em municípios produtores de citros no Rio Grande do Sul. Pesquisa Agropecuária Brasileira, v.37, n.4, p.553-558, 2002.

SPIEGEL-ROY, P.; GOLDSCHMIDT, E.E. Biology of citrus. Cambridge: Cambridge University Press, 1996. 230p. 
STANGARLIN, J.R. Atividades de ribulose-1,5-bifosfato carboxilase (Rubisco), clorofilase, $\beta$-1,3-glucanase e quitinase e conteúdo de clorofila em cultivares de feijoeiro (Phaseolus vulgaris) infectados com Uromyces appendiculatus ou Phaeoisariopsis griseola. Piracicaba, 1999. 119p. Tese (Doutorado) - Escola Superior de Agricultura "Luiz de Queiroz", Universidade de São Paulo.

SUKARNO, N.; SMITH, S.E.; SCOTT, E.S. The effect of fungicides on vesiculararbuscular mycorrhizal symbiosis. I. The effects on vesicular-arbuscular mycorrhizal fungi and plant growth. New Phytologist, v.125, n.1, p.139-147, 1993.

TEÓFILO SOBRINHO, J. Propagação dos citros. In: RODRIGUEZ, O.; VIÉGAS, F.C.P. (Ed.). Citricultura brasileira. Campinas: Fundação Cargill, 1980. cap.12, p.297-318.

TRAPPE, J.M.; MOLINA, R.; CASTELLANO, M. Reactions of mycorrhizal fungi and mycorrhiza formation to pesticides. Annual Review of Phytopathology, v.22, p.331-359, 1984.

TrotTA, A., VARESE, G.C.; GNAVI, E.; FUSCONI, A., SAMPÒ, S.; BERTA, G. Interactions between the soilborne root pathogen Phytophthora nicotianae var. parasitica and the arbuscular mycorrhizal fungus Glomus mosseae in tomato plants.

Plant and Soil, v.185, n.2, p.199-209, 1996.

TSAO, P.H. Factors affecting isolation and quantitation of Phytophthora from soil. In: ERWIN, D.C.; BARTNICKI-GARCIA, S.; TSAO, P.H. (Ed.). Phytophthora: its biology, taxonomy, ecology and pathology. St. Paul: APS Press, 1983. p.219-236.

VAN LOON, L.C. Pathogenesis-related proteins. Plant Molecular Biology, v.4, n.2, p.111-116, 1985.

VAN LOON, L.C.; VAN STRIEN, E.A. The families of pathogenesis-related proteins, their activities, and comparative analysis of PR-1 type proteins. Physiological and Molecular Plant Pathology, v.55, p.85-97, 1999.

VANCE, E.D.; BROOKES, P.C.; JENKINSON, D.S. An extraction method for measuring soil microbial biomass C. Soil Biology and Biochemistry, v.19, p.703$707,1987$. 
VELAZCO, C.L. Indução de supressividade a Phytophthora nicotianae em mudas de limão cravo com lodo de esgoto. Piracicaba, 2002. 66p. Dissertação (Mestrado) Escola Superior de Agricultura "Luiz de Queiroz", Universidade de São Paulo.

VENZKE FILHO, S. de P. Microbiota e sua atividade em uma cronossequência sob sistema plantio direto. Piracicaba, 1999. 65p. Dissertação (Mestrado) - Escola Superior de Agricultura "Luiz de Queiroz", Universidade de São Paulo.

VIERHEILIG, H.; COUGHLAN, A.P.; WYSS, U.; PICHÉ, Y. Ink and vinegar, a simple staining technique for arbuscular-mycorrhizal fungi. Applied and Environmental Microbiology, v.64, p.5004-5007, 1998.

WARDLE, D.A. Metodologia para quantificação da biomassa microbiana do solo. In: HUNGRIA, M.; ARAÚJO, R.S. (Ed.) Manual de métodos empregados em estudos de microbiologia agrícola. Londrina: EMBRAPA, 1994. p.419-436.

WEBER, O.B.; OLIVEIRA, E. Ocorrência de fungos micorrízicos vesículoarbusculares em citros nos Estados da Bahia e Sergipe. Pesquisa Agropecuária Brasileira, v.29, n.12, p.1905-1914, 1994.

WESTE, G. Population dynamics and survival of Phytophthora. In: ERWIN, D.C.; BARTNICKI-GARCIA, S.; TSAO, P.H. (Ed.). Phytophthora: its biology, taxonomy, ecology and pathology. St. Paul: APS Press, 1983. p.237-257.

WHITESIDE, J.O.; GARNSEY, S.M.; TIMMER, L.W. (Ed). Compendium of citrus diseases. St. Paul: APS Press, 1993. 80p. 